\title{
ASSESSMENT OF PCFBC FIELD-EXPOSED ADVANCED CANDLE FILTERS
}

Topical Report

DOE/FETC Contract No. DE-AC21-94MC31147

March 31, 1997

by
M. A. Alvin
T. E. Lippert
E. S. Diaz
Westinghouse Science and Technology Center 1310 Beulah Road Pittsburgh, PA 15235-5098

\author{
Prepared for \\ U.S. Department of Energy \\ Office of Fossil Energy \\ Federal Energy Technology Center \\ Morgantown, West Virginia
}

R. A. Dennis - DOE/FETC Project Manager 


\section{DISCLAIMER}

This report was prepared as an account of work sponsored by the United States Government. Neither the United States nor the United States Department of Energy, nor any of their employees, makes any warranty, expressed or implied, or assumes any legal liability or responsibility for the accuracy, completeness, or usefulness of any information, apparatus, product, or process disclosed, or represents that its use would not infringe privately owned rights. Reference herein to any specific commercial product, process, or service by trade name, mark, manufacturer, or otherwise, does not necessarily constitute or imply its endorsement, recommendation, or favoring by the United States Government or any agency thereof. The views and opinions of authors expressed herein do not necessarily state or reflect those of the United States Government or any agency thereof. 



\section{TABLE OF CONTENTS}

$\underline{\text { Page }}$

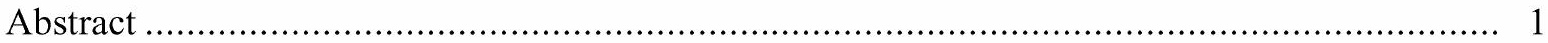

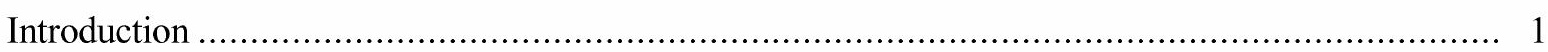

Filter Characterization ........................................................................................... 5

Room Temperature Gas Flow Resistance................................................... 5

Compressive and Tensile Strength.................................................................. 5

Hoop Stress, Elastic Modulus, and Poisson's Ratio ..................................................... 19

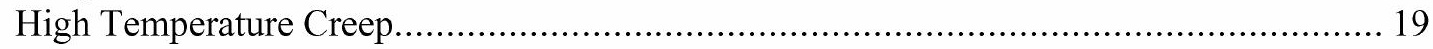

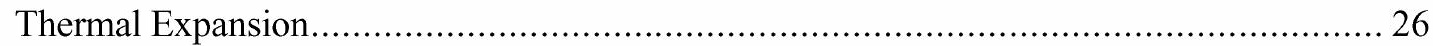

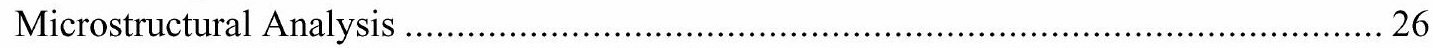

Schumacher Dia Schumalith FT20 Candle Filters ......................................... 30

Pall 326 Candle Filters ................................................................................... 30

Coors P-100A-1 Alumina/Mullite Candle Filters............................................... 44

3M CVI-SiC Composite Candle Filters...................................................... 44

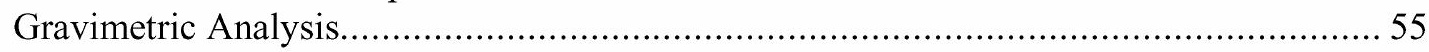

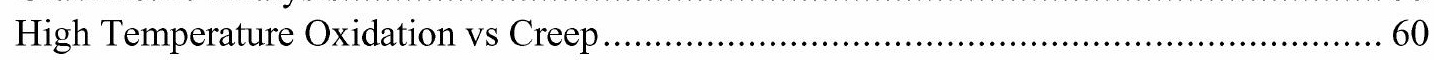

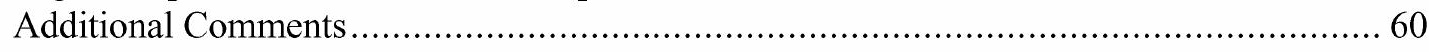

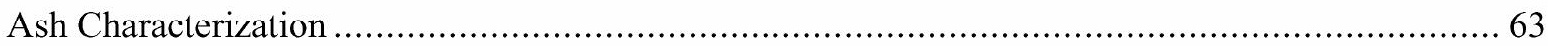

Scanning Electron Microscopy/Energy Dispersive X-Ray Analysis ............................. 63

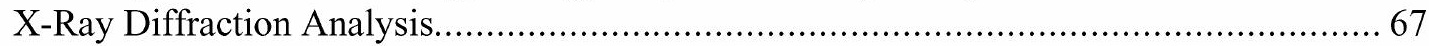

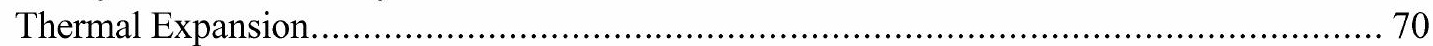

Density, Moisture Content, and Compressive Strength ............................................ 70

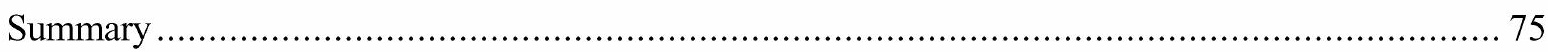

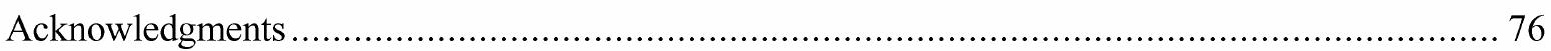





\section{LIST OF TABLES}

1 Summary of PCFBC testing

2 As-manufactured and residual process temperature strength of the PCFBC-exposed porous ceramic filter materials

3 Ultimate load applied during strength characterization of the porous ceramic filter materials.

4 Fracture characteristics of the porous ceramic filter materials during c-ring compressive

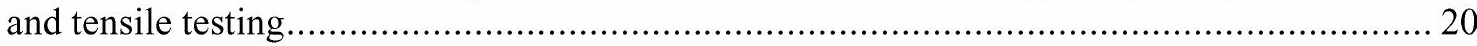

5 Material properties of the PCFBC-exposed porous ceramic candle filters......................... 24

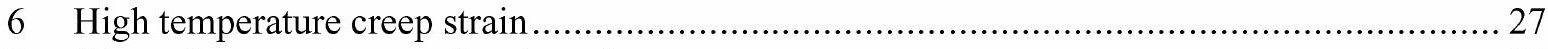

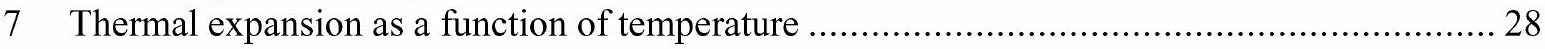

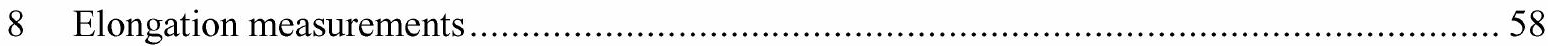

9 Silica concentration in the as-manufactured and PCFBC-exposed clay bonded silicon

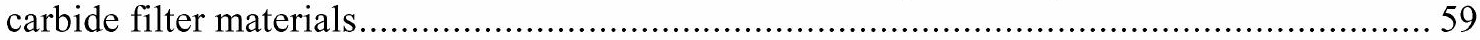

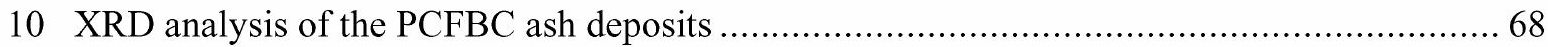

11 XRD analysis of the candle filter residual dust cake layer and ash bridged materials ............. 69

12 Ash deposit characterization ................................................................................. 72

13 Room temperature compressive strength of PCFBC ash deposits ................................. 74 



\section{LIST OF FIGURES}

$\underline{\text { Page }}$

1 The Westinghouse Advanced Particulate Filtration system utilized at the Foster Wheeler pressurized circulating fluidized-bed combustion test facility in Karhula, Finland. ............... 2

2 Room temperature gas flow resistance of the as-manufactured candle filters....................... 6

3 Room temperature gas flow resistance of the surveillance candle filters that were removed from the cluster assembly at the conclusion of Test Segment 2 ....................... 7

4 Room temperature gas flow resistance of the surveillance candle filters that were

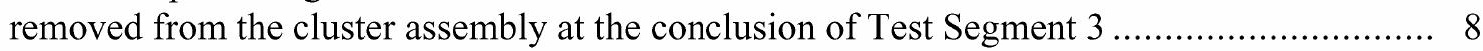

5 PCFBC dust cake deposits that formed along the outer surface of the candle filters at the conclusion of Test Segment 2............................................................................ 9

6 PCFBC dust cake deposits that formed along the outer surface of the candles at the

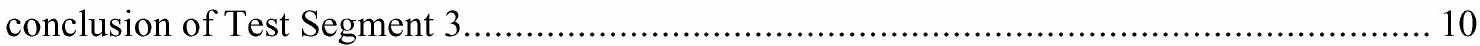

7 Residual process temperature compressive strength of the PCFBC-exposed candle filters ...... 11

8 Residual process temperature tensile strength of the PCFBC-exposed candle filters .............. 12

9 High temperature creep strain of the field-tested clay bonded silicon carbide filter

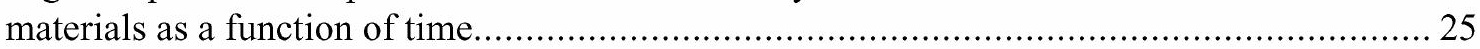

10 Thermal expansion of the PCFBC-exposed Schumacher Dia Schumalith FT20 filter

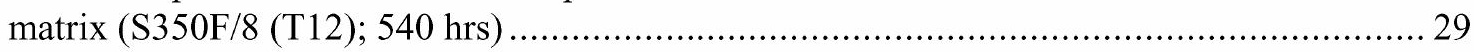

11 Thermal expansion of the PCFBC-exposed Pall 326 filter matrix (R5-665 (M21);

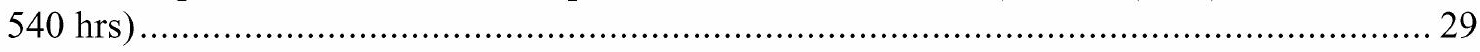

12 Microstructure of the 540 hour, PCFBC-exposed, Schumacher Dia Schumalith FT20

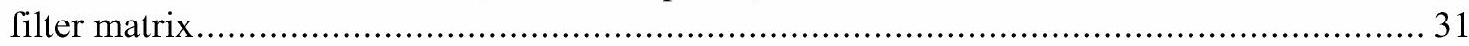

13 Microstructure of the 1166 hour, PCFBC-exposed, Schumacher Dia Schumalith FT20

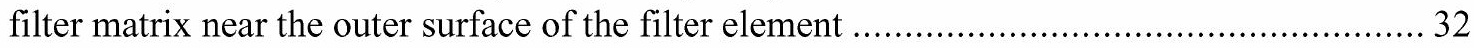

14 Melt-like appearance of the coating that encapsulated the silicon carbide grains in the 1166 hour, PCFBC-exposed, Schumacher Dia Schumalith FT20 filter matrix near the

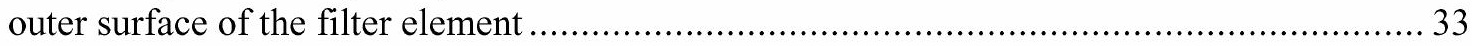

15 Microstructure of the 1166 hour, PCFBC-exposed, Schumacher Dia Schumalith FT20 filter matrix near the center of the filter wall............................................................. 34

16 Extensive crystallization that resulted along the coating that encapsulated the silicon carbide grains in the 1166 hour, PCFBC-exposed, Schumacher Dia Schumalith FT20 filter matrix near the center of the filter wall......................................................... 35

17 Morphology of the mullite-enriched phase that encapsulated the 1166 hour, PCFBCexposed, silicon carbide grains in the Schumacher Dia Schumalith FT20 filter matrix

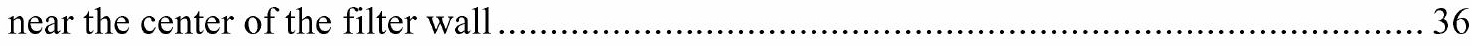

18 Morphology of the 540 hour, PCFBC-exposed, Pall 326 filter matrix.............................. 37

19 Microstructure of the cross-sectioned, 1166 hour, PCFBC-exposed, Pall 326 filter matrix near the outer surface of the filter element.

20 Extensive crystallization that resulted along the coating that encapsulated the silicon carbide grains in the 1166 hour, PCFBC-exposed, Pall 326 filter matrix near the outer surface of the filter wall...

21 Higher magnification micrograph montage illustrating the extensive crystallization that resulted along the surface of the binder-enriched oxide coated silicon carbide grains in the 1166 hour, PCFBC-exposed, Pall 326 filter matrix 
22 Micrograph illustrating the thickness of the binder-enriched oxide coating that remained

along the surface of the silicon carbide grains in the 1166 hour, PCFBC-exposed, Pall

326 filter matrix

23 Higher magnification micrograph montage illustrating the melt-like features of the binder-enriched oxide coating that encapsulated the silicon carbide grains near the outer surface of the 1166 hour, PCFBC-exposed, Pall 326 filter element

24 Microstructure of the 1166 hour, PCFBC-exposed, Pall 326 filter matrix near the pulse cycled surface of the filter element.

25 Morphology of the silica-enriched oxide coating that encapsulated the silicon carbide grains in the 1166 hour, PCFBC-exposed, Pall 326 filter element

26 High magnification micrograph montage illustrating extensive crystallization of the binder-enriched oxide coating that encapsulated the silicon carbide grains along the pulse cycled surface of the 1166 hour, PCFBC-exposed, Pall 326 filter element, and the mottled surface features of the underlying silicon carbide grains.

27 Microstructure of the 505 hour, PCFBC-exposed, Coors P-100A-1 alumina/mullite filter

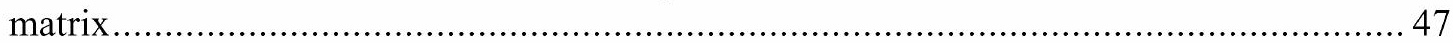

28 Microstructure of the 1650 Hour, PFBC/PCFBC-exposed, Coors P-100A-1 alumina/ mullite filter matrix

29 High magnification micrograph montage illustrating the extensive crystallization that resulted throughout the ligaments and along the pore cavity surfaces of the 2276 hour, PFBC/PCFBC-exposed, Coors P-100A-1 alumina/mullite matrix

30 Micrograph montage illustrating the formation of mullite-like rods that resulted along the surface of the pore cavity walls in the PFBC/PCFBC-exposed Coors P-100A-1 alumina/ mullite filter matrix.

31 High magnification micrograph montage illustrating the formation of a fine grain phase and mullite-like rods that resulted along the pore cavity surfaces of the 1166 hour, PCFBC-exposed, Coors P-100A-1 alumina/mullite filter matrix.

32 Micrograph illustrating the morphology of the larger grain aluminosilicate phase that resulted along the pore cavity surfaces of the PFBC/PCFBC-exposed Coors P-100A-1 alumina/mullite filter matrix ....

33 Morphology of the crystalline features that typically formed at the tip of the mullite rods which extended into the pore cavities of the PCFBC-exposed, Coors P-100A-1 alumina/ mullite filter matrix.

34 Color gradient resulting along the length of the 3M CVI-SiC composite filters after operation in the PCFBC environment

35 Oxidation resulting along the outer and inner surfaces of the CVI-SiC encapsulating shell of the filtration mat fibers in the 387 hour, PCFBC-exposed, $3 \mathrm{M}$ composite filter matrix ....... 56

36 Oxidation and pitting that resulted along the outer surface of the CVI-SiC shell that encapsulated the Nextel ${ }^{\mathrm{TM}} 312$ filaments in the 387 hour, PCFBC-exposed, $3 \mathrm{M}$ composite filter matrix

37 Crack formations along the flange of the 3M CVI-SiC composite candle filter after 626 hours of PCFBC operation in Test Segment 3.

38 Removal of the outer confinement and filtration mat layers in the 626 hour, PCFBCexposed, 3M CVI-SiC composite filter element (Test Segment 3).

39 Crack formations around the densified plug insert in the 1166 hour, PCFBC-exposed, Pall 326 filter elements (Test Segment 3) 
40 Morphology of the PCFBC dust cake deposit that formed along the surface of the candle filters at the conclusion of Test Segment 2 in April 1996.

41 Micrograph indicating extensive interconnectivity within the highly porous PCFBC dust cake deposit that formed along the surface of the candle filters at the conclusion of Test Segment 2 in April 1996

42 Thermal expansion of the porous ceramic filter materials and ash formations...................... 71 


\title{
ASSESSMENT OF PCFBC FIELD-EXPOSED ADVANCED CANDLE FILTERS
}

\author{
M. A. Alvin \\ T. E. Lippert \\ E. S. Diaz \\ March 31, 1997 \\ Westinghouse Science and Technology Center \\ 1310 Beulah Road \\ Pittsburgh, PA 15235-5098
}

\begin{abstract}
Commercially available oxide and nonoxide-based monolithic and advanced fiber reinforced candle filters were installed and operated for a maximum of 626-1166 hours in the Westinghouse Advanced Particulate Filtration system at the Foster Wheeler pressurized circulating fluidized-bed combustion test facility in Karhula, Finland. The response and performance of the porous ceramic filter materials to extended operation in the high temperature, oxidizing environment, and information regarding the chemistry and morphology of the dust cake deposits formed throughout the filter cluster assembly are presented in this report. ${ }^{\dagger}$

As a result of testing at Karhula, the oxide-based Coors P-100A-1 alumina/mullite candle filters continue to show promise for achieving extended operating life in advanced coal-fired applications. Additional testing in the high temperature PCFBC oxidizing environment is essential to determine the viability of the high temperature creep resistant clay bonded Schumacher Dia Schumalith FT20 and Pall 326 candle filters, as well as the $3 \mathrm{M} \mathrm{CVI-SiC}$ composite filter elements.
\end{abstract}

\section{Introduction}

Hot gas filtration testing was initiated in the Westinghouse Advanced Particulate Filtration (W-APF) system (Figure 1) in November 1995 at the Foster Wheeler pressurized circulating fluidized bed combustion (PCFBC) test facility in Karhula, Finland. Three test campaigns were conducted

\footnotetext{
$\dagger$ Research sponsored by the U.S. Department of Energy’s Federal Energy Technology Center in Morgantown, WV, under contract DE-AC21-94MC31147 with the Westinghouse Science \& Technology Center, 1310 Beulah Road, Pittsburgh, PA. 15235-5098; Telefax: 412-256-2121.
} 


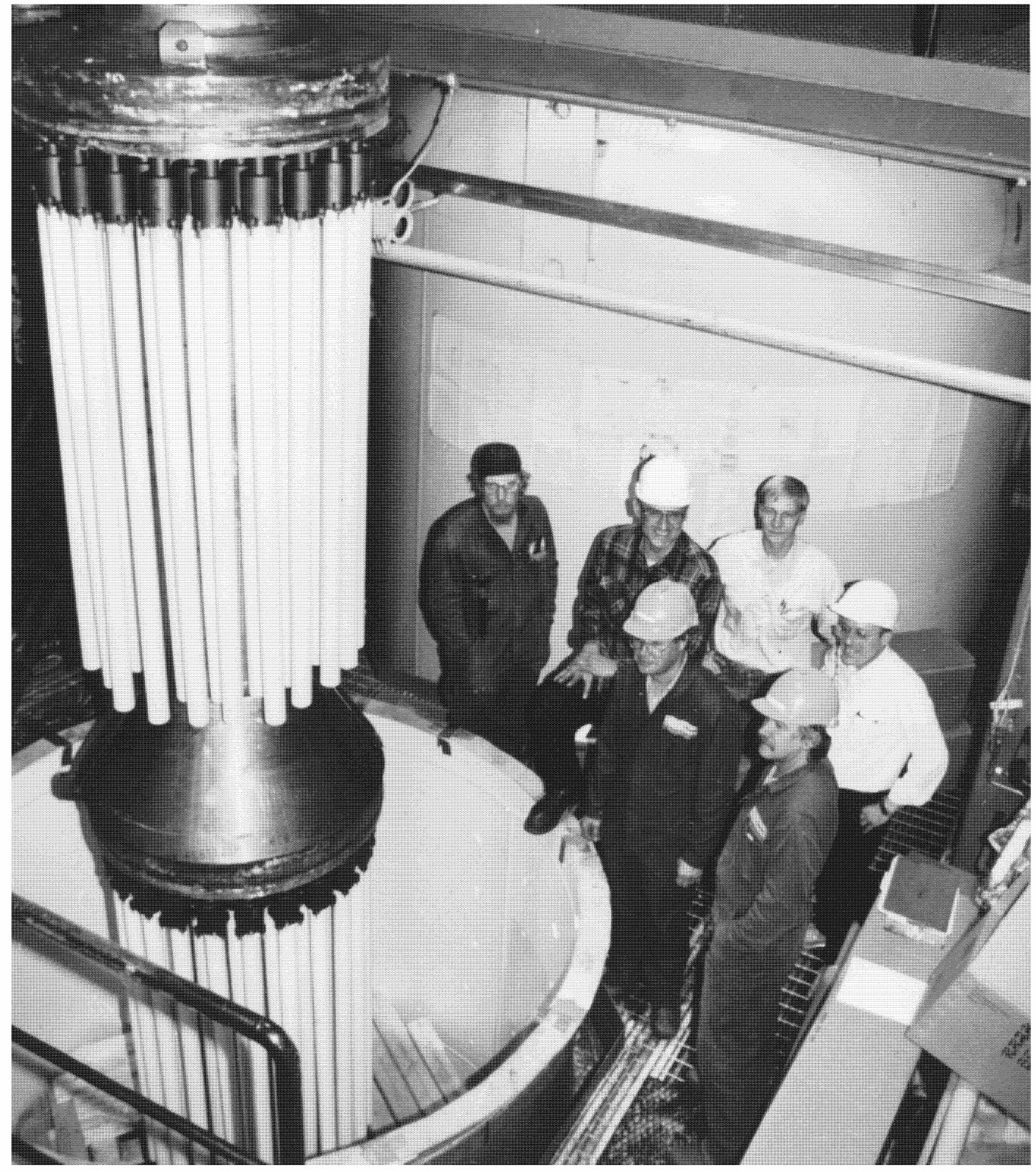

Figure 1 - The Westinghouse Advanced Particulate Filtration system utilized at the Foster Wheeler pressurized circulating fluidized-bed combustion test facility in Karhula, Finland. 
utilizing $1.5 \mathrm{~m}$ high temperature creep resistant clay bonded silicon carbide Schumacher Dia Schumalith FT20 and Pall 326 candle filters in the top and middle arrays, respectively, and a mixture of the $1.5 \mathrm{~m}$ Coors P-100A-1 alumina/mullite and $1.5 \mathrm{~m} 3 \mathrm{M}$ CVI-SiC composite filter elements in the bottom array (Table 1). In addition, five Coors P-100A-1 alumina/mullite candle filters which had been operated for a period of 1110 hours in the W-APF system at the American Electric Power (AEP) pressurized fluidizedbed combustion (PFBC) Tidd demonstration plant in Brilliant, Ohio, were installed in the bottom array. A total of 1166 hours of hot gas filtration testing was achieved during the 1995-1996 test program in Karhula, Finland.

During Test Segment 1, the $\underline{\mathrm{W}}-\mathrm{APF}$ was filled with 112 filter elements, and was operated for a period of 153 hours at temperatures of $826-853^{\circ} \mathrm{C}$. Illinois No. 6 coal and Linwood limestone were utilized as the feed and sorbent materials. After an initial 22 hours of commissioning, the pressure vessel was slow cooled as a result of plant maintenance, and the three filter arrays were inspected. The $3 \mathrm{M}$ CVI-SiC composite candles which were observed to be somewhat loose within the metal filter holders were remounted and tightened to assure adequate sealing. Testing was reinitiated for a period of 35 hours, prior to a second maintenance outage. Inspection of the filter arrays indicated that failure along the flange of several $3 \mathrm{M} \mathrm{CVI-SiC} \mathrm{composite} \mathrm{filters} \mathrm{resulted} \mathrm{due} \mathrm{to} \mathrm{the} \mathrm{tight} \mathrm{clamping} \mathrm{and} \mathrm{fixturing} \mathrm{of} \mathrm{the}$ elements within the metal holders. All of the 3M CVI-SiC composite filters which had initially been installed within the W-APF were removed in order to eliminate the risk of potential catastrophic failure of the elements during extended PCFBC operation. Testing was reinitiated and continued for an additional 118 hours. After slow cooling of the array in December 1995, post-test inspection of the cluster was conducted which indicated that all filter elements remained intact.

Nine newly manufactured 3M CVI-SiC composite filters were installed in the bottom array, and testing in Test Segment 2 which was initiated in February 1996 continued for a period of 387 hours prior to shutdown in April 1996. Once again the 112 candle filter cluster assembly was operated at temperatures of $818-860^{\circ} \mathrm{C}$, removing fines generated during the combustion of Illinois No. 6 coal and Linwood limestone. Post-test inspection of the $\underline{\mathrm{W}}$-APF in April 1996 indicated that failure of five Coors P-100A-1 alumina/mullite candle filters, four 3M CVI-SiC composite filter elements, and one Schumacher Dia Schumalith FT20 filter had occurred during process shutdown primarily as a result of ash bridging between the candles, metal holders, and plenum pipes. ${ }^{1}$

All filter elements were removed from the $\underline{W}$-APF at the conclusion of Test Segment 2. The cluster was recandled with previously used and newly manufactured filter elements, and testing was reinitiated in August 1996. As in the first two test segments, the high temperature creep resistant clay bonded silicon carbide Schumacher Dia Schumalith F20 filter elements were positioned within the top array, comparable Pall 326 filters filled the middle array, and a mixture of Coors P-100A-1 alumina/mullite and 3M CVI-SiC composite elements filled the bottom array. The 128 candle filter cluster assembly was subjected to 626 hours of PCFBC operation, at temperatures of $838-860^{\circ} \mathrm{C}$ during Test Segment 3. In this test campaign both Iowa Industrial limestone and resized Linwood limestone were utilized as sorbents in conjunction with Illinois No. 6 coal. Post-test inspection of the array in October 1996 indicated that limited bridging was evident within the various arrays. All elements remained intact and were subsequently removed from the cluster assembly. Inspection of the clay bonded silicon carbide filter elements indicated that after 1166 hours of PCFBC operation, the $1.5 \mathrm{~m}$ candles elongated by $6-9 \mathrm{~mm}$.

\footnotetext{
${ }^{1}$ The fractured surface of the filter elements was ash-free implying that failure of the elements occurred during plant shutdown as opposed to during plant operation.
} 


\section{TABLE 1}

\section{SUMMARY OF PCFBC TESTING}

\begin{tabular}{|l|c|c|c|}
\hline \multicolumn{1}{|c|}{ Test Segment } & $\begin{array}{c}\mathbf{1} \\
\mathbf{( 1 1 / 1 9 9 5 - 1 2 / 1 9 9 5 )}\end{array}$ & $\begin{array}{c}\mathbf{2} \\
\mathbf{( 2 / 1 9 9 6 - 4 / 1 9 9 6 )}\end{array}$ & $\begin{array}{c}\mathbf{3} \\
\mathbf{( 8 / 1 9 9 6 - 1 0 / 1 9 9 6 )}\end{array}$ \\
\hline Coal & Illinois No. 6 (Sparta) & Illinois No. 6 (Sparta) & Illinois No. 6 (Sparta) \\
\hline Sorbent & Linwood Limestone & Linwood Limestone & $\begin{array}{c}\text { Linwood Limestone } \\
\text { Iowa Industrial Limestone } \\
\text { Resized Linwood } \\
\text { Limestone }\end{array}$ \\
\hline Number of Candles & & & 128 \\
\hline Schumacher FT20 & 112 & 112 & 46 \\
\hline Pall 326 & $32-35$ & 35 & 45 \\
\hline Coors Alumina/Mullite & $32-35$ & 35 & $32(4)^{(\mathrm{a})}$ \\
\hline 3M CVI-SiC Composite & $24-0$ & $33(5)^{(\mathrm{a})}$ & 5 \\
\hline Operating Hours (Coal) & $153^{(\mathrm{b})}$ & 9 & 626 \\
\hline Operating Temperature, ${ }^{\circ} \mathrm{C}$ & $826-853$ & 387 & $838-860$ \\
\hline Operating Pressure, bar & $10.7-11.1$ & $818-860$ & $10.5-10.7$ \\
\hline Nominal Face Velocity, cm/s & $3.5-4.1$ & $10.6-11.3$ & $3.0-3.4$ \\
\hline Inlet Dust Loading, ppmw & $12,000-13,500$ & $3.1-4.2$ & $11,000-12,500$ \\
\hline $\mathrm{d}_{50}, \mu m$ (Malvern) & NA & $12,000-15,500$ & $23(20-26)$ \\
\hline
\end{tabular}

(a) Number of installed PFBC-exposed Coors filter elements (AEP Test Segment 5) shown in parentheses.

(b) Thirty-five hours of initial operation prior to removal of the 3M CVI-SiC composite filters, followed by 118 hours of continuous operation.

NA: Not available. 
After each test campaign, surveillance filter elements were removed from the cluster and were subjected to both nondestructive and destructive materials characterization in order to identify the overall integrity of each element, as well as to determine the residual strength of the various filter matrices at process operating temperature, and any microstructural changes that may have occurred as a result of operation in the PCFBC environment. Additional analyses were focused on determining the residual high temperature creep characteristics of the PCFBC-exposed clay bonded silicon carbide filter elements, their potential to undergo oxidation which fostered elongation of the Schumacher Dia Schumalith FT20 and Pall 326 candles by 6-9 mm after 1166 hours of PCFBC operation, and the associated impact of ash and ash chemistry on the stability of the various filter matrices. The results of these efforts are presented in the following sections.

\section{Filter Characterization}

\section{Room Temperature Gas Flow Resistance}

The gas flow resistance of the as-manufactured Schumacher Dia Schumalith FT20, Pall 326, Coors P-100A-1 alumina/mullite, and 3M CVI-SiC composite candle filters is shown in Figure 2. All as manufactured candle filters initially met the Westinghouse room temperature gas flow resistance tolerance of $\leq 1.0 \mathrm{in}-\mathrm{wg} / \mathrm{fpm}$.

Similar gas flow resistance measurements were obtained for the PCFBC surveillance filter elements that were returned to Westinghouse at the conclusion of Test Segments 2 and 3 (Figures 3 and 4). A significant increase in the room temperature gas flow resistance across each element resulted after testing at Karhula. The nature and thickness of the ash cake layer that remained along the outer surface of each filter element typically governed the resulting gas flow resistance of each PCFBC-tested filter element (Figures 5 and 6).

\section{Compressive and Tensile Strength}

Strength characterization of the as-manufactured Schumacher Dia Schumalith FT20, Pall 326, Coors P-100A-1 alumina/mullite, and 3M CVI-SiC composite candle filters was conducted via compressive and tensile testing of $15 \mathrm{~mm}$ c-ring sections at room temperature, $850^{\circ} \mathrm{C}, 870^{\circ} \mathrm{C}$, and $900^{\circ} \mathrm{C}$ (Figures 7 and 8; Tables 2 and 3). ${ }^{2}$ In addition, Coors P-100A-1 alumina/mullite and 3M CVI-SiC composite candles removed after completion of Test Segments 1 and 2, and Schumacher Dia Schumalith FT20 and Pall 326 filters removed after completion of Test Segment 2 were subjected to c-ring compressive and tensile strength testing at room temperature, $850^{\circ} \mathrm{C}$, and $900^{\circ} \mathrm{C}$. Process temperature strengths (i.e., $850^{\circ} \mathrm{C}$ ) of sections from broken filter elements that were removed from the ash hopper at the conclusion of Test Segment 2 were also identified. Compressive and tensile strength testing of the surveillance candles that were removed at the conclusion of Test Segment 3 was conducted at room temperature and at $850^{\circ} \mathrm{C}$.

The as-manufactured Schumacher Dia Schumalith FT20 and Coors P-100A-1 alumina/mullite filter materials retained their brittle fracture characteristics during c-ring compressive and tensile testing

\footnotetext{
${ }^{2} \mathrm{C}$-ring compressive strength testing places the o.d. surface of the sample in tension. In contrast c-ring tensile strength testing places the i.d. surface of the sample in tension.
} 


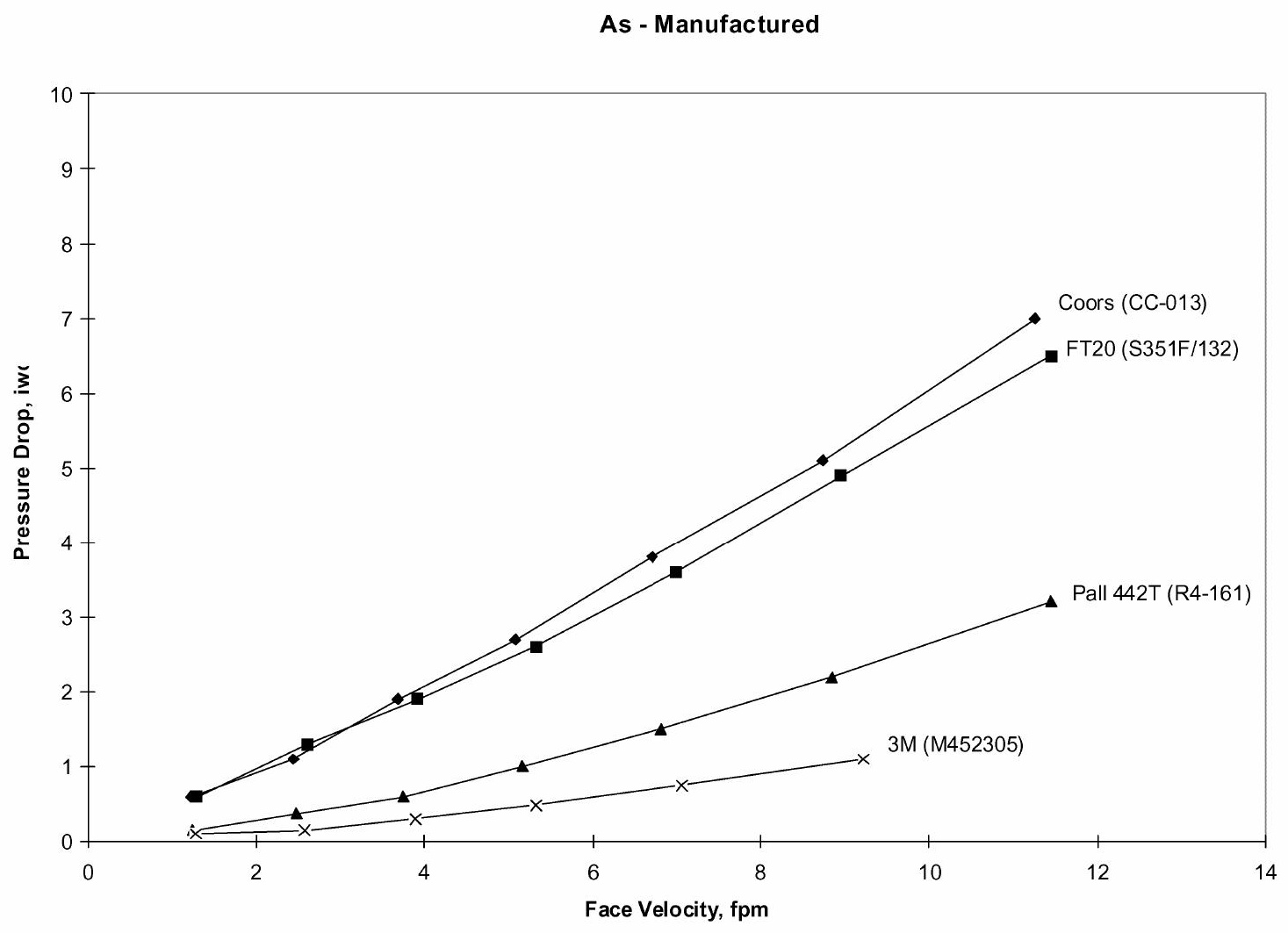

Figure 2 - Room temperature gas flow resistance of the as-manufactured candle filters. 
Test Segment 2

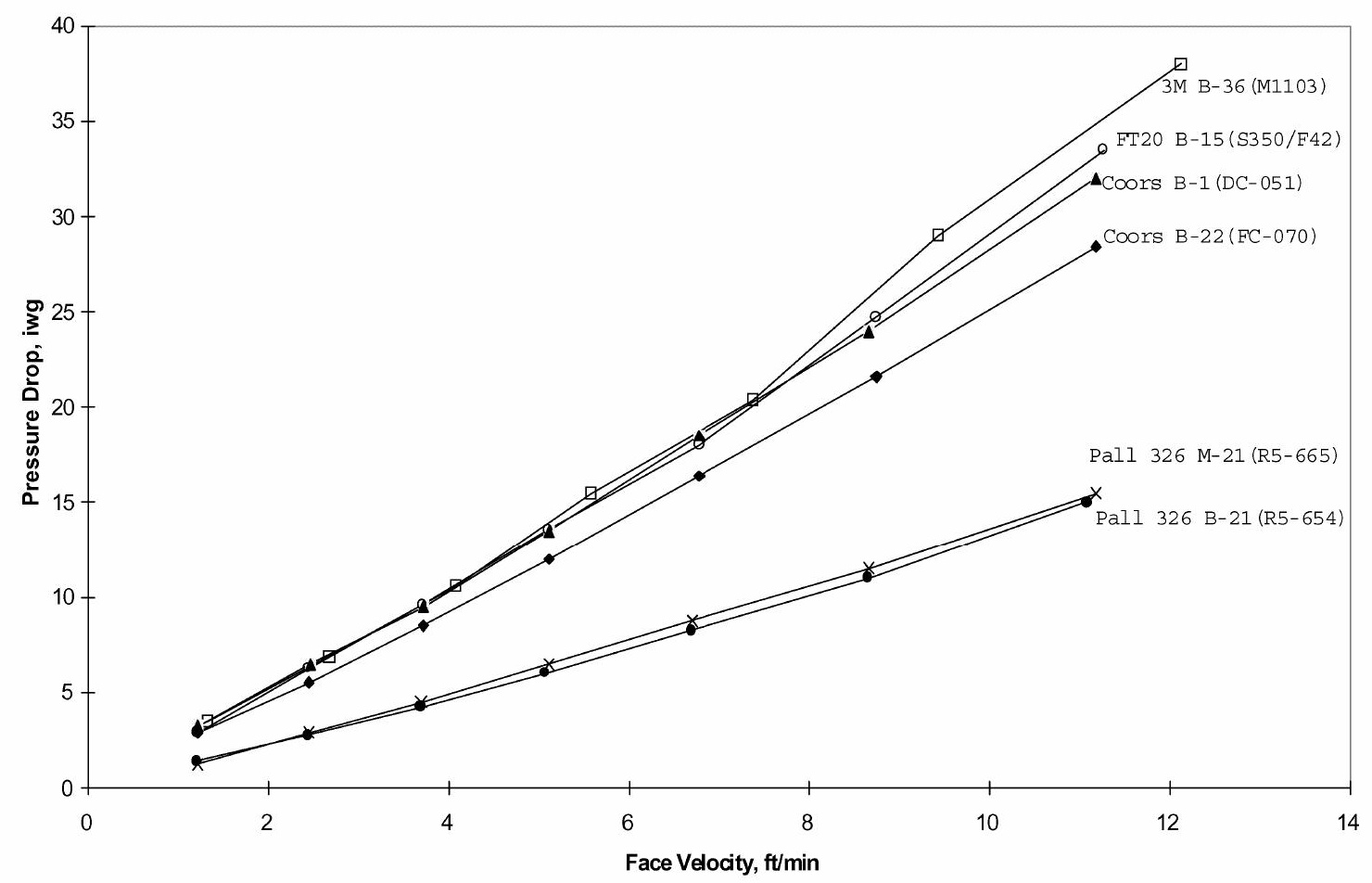

Figure 3 - Room temperature gas flow resistance of the surveillance candle filters that were removed from the cluster assembly at the conclusion of Test Segment 2. 
Test Segment 3

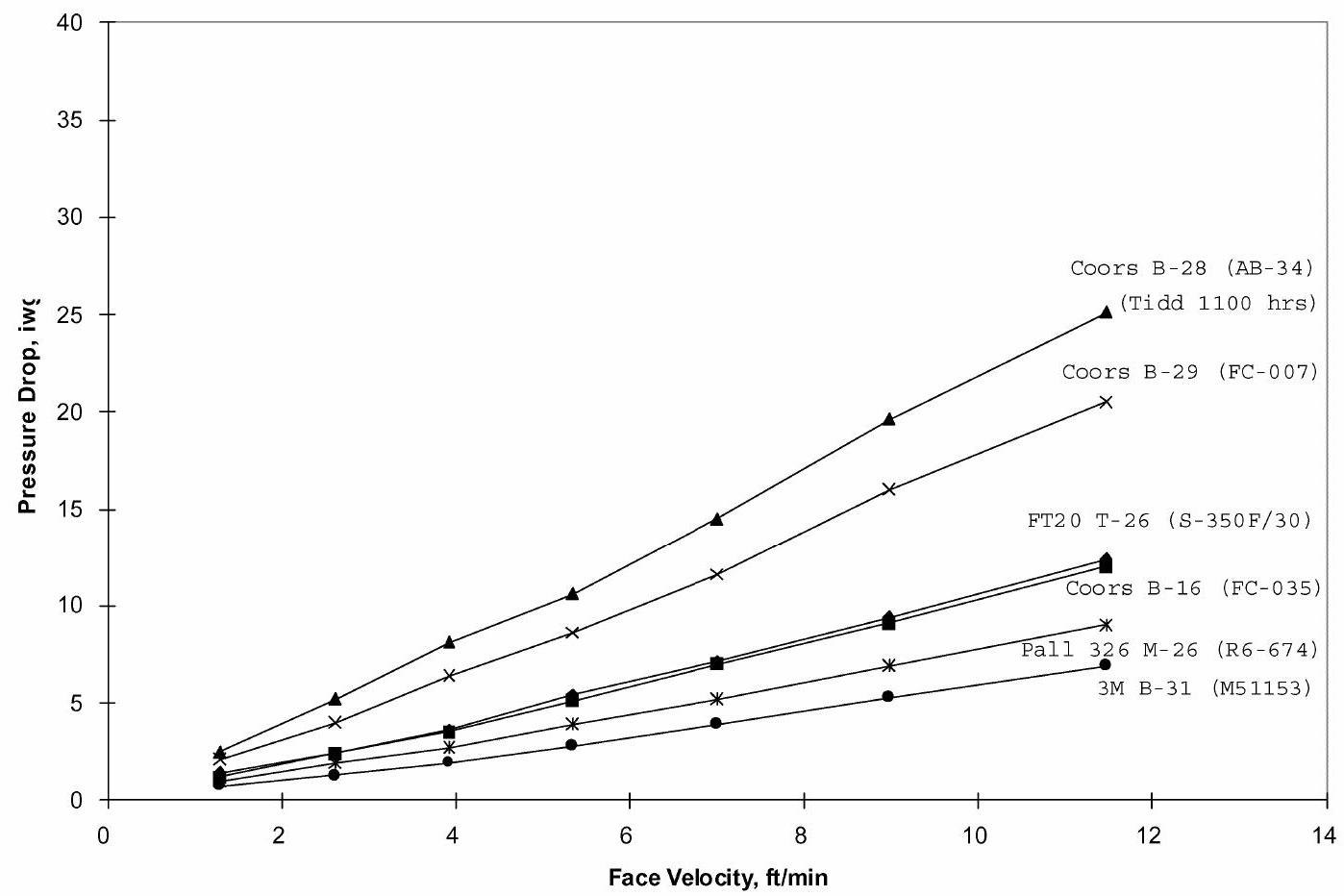

Figure 4 - Room temperature gas flow resistance of the surveillance candle filters that were removed from the cluster assembly at the conclusion of Test Segment 3. 


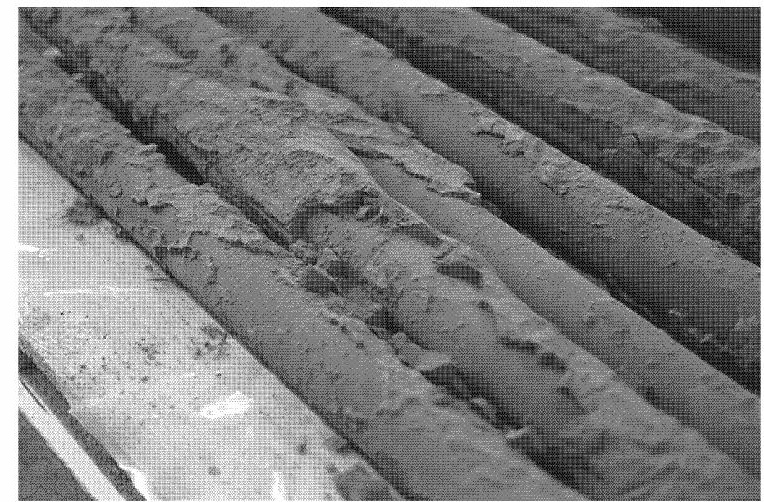

Schumacher Dia Schumalith FT20

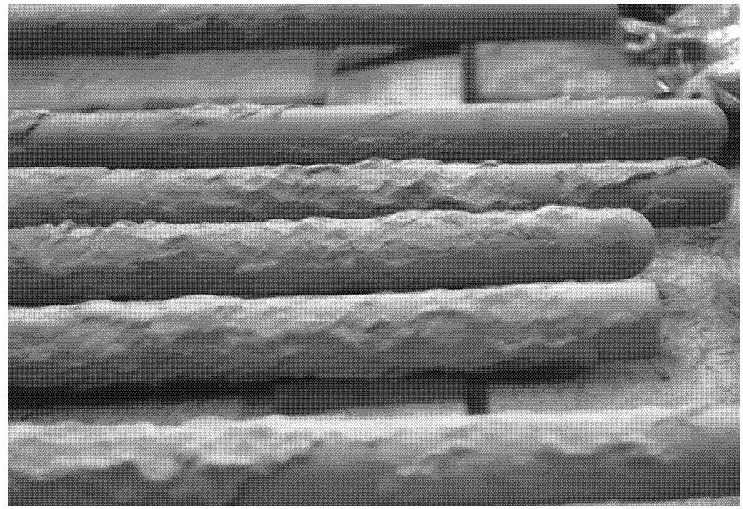

Coors P-100A-1 Alumina/Mullite

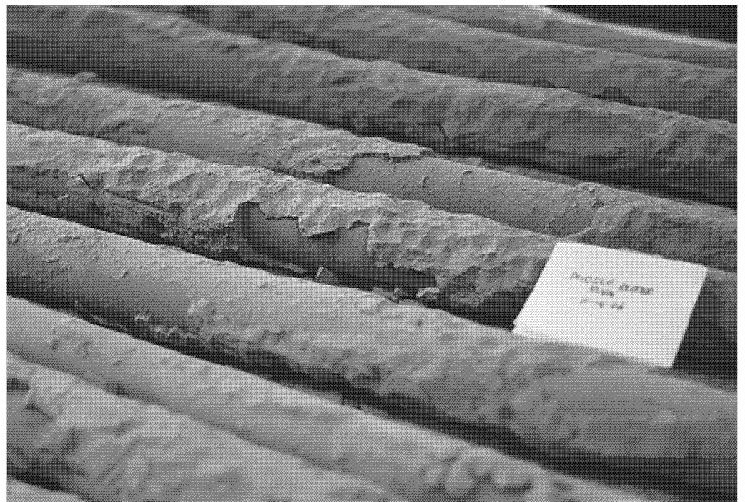

Pall 326

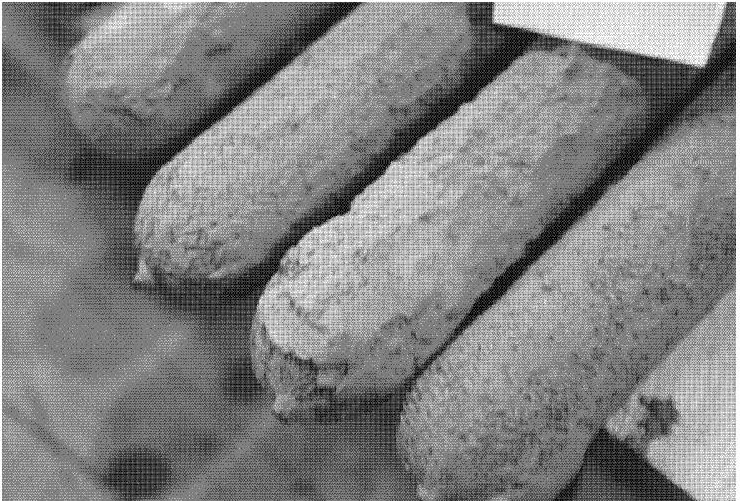

3M CVI-SiC Composite

Figure 5 - PCFBC dust cake deposits that formed along the outer surface of the candle filters at the conclusion of Test Segment 2. 


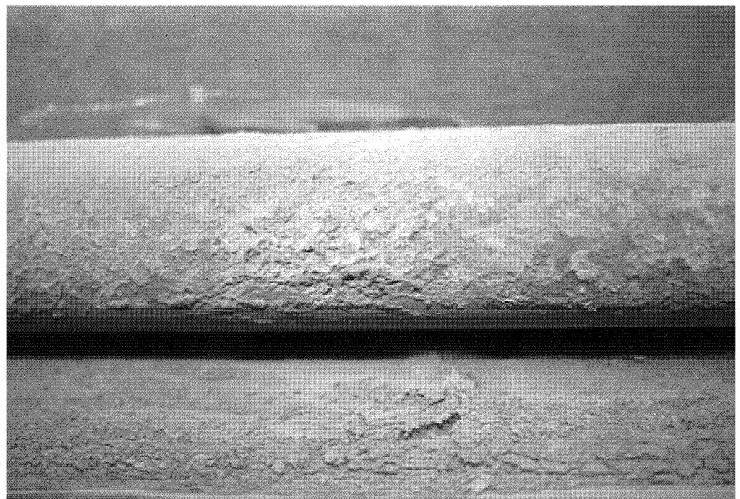

Schumacher Dia Schumalith FT20

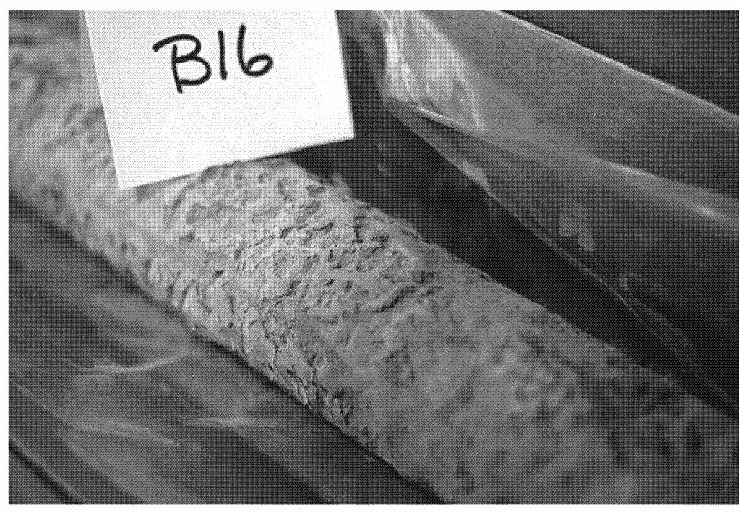

Coors P-100A-1 Alumina/Mullite

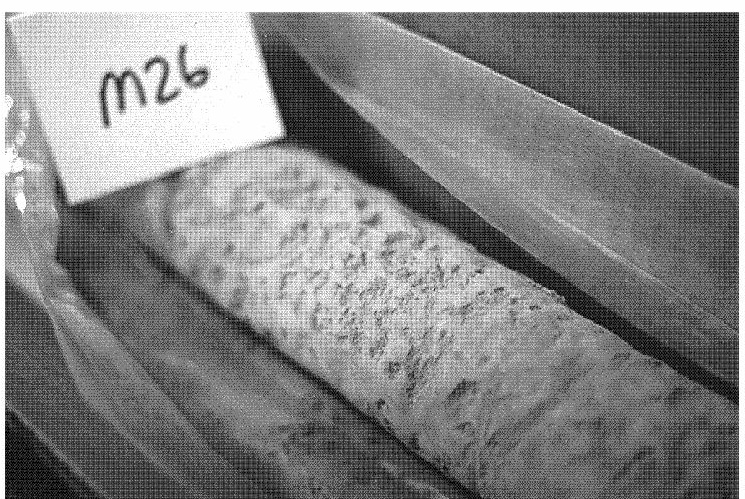

Pall 326

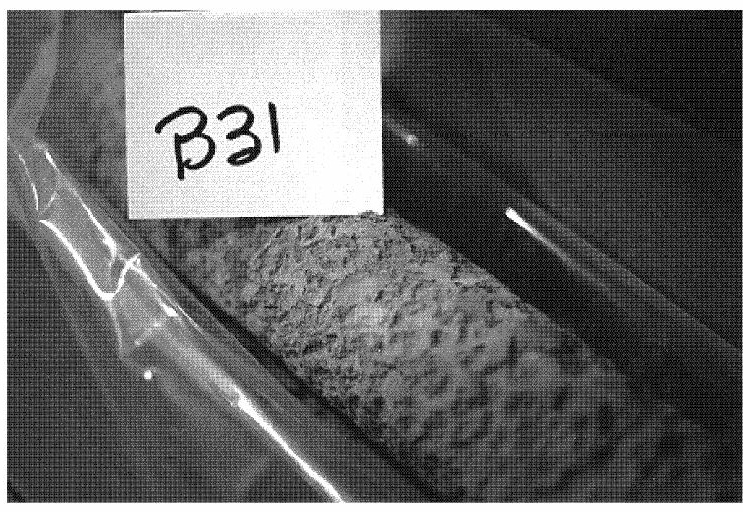

3M CVI-SiC

Figure 6 - PCFBC dust cake deposits that formed along the outer surface of the candles at the conclusion of Test Segment 3. 


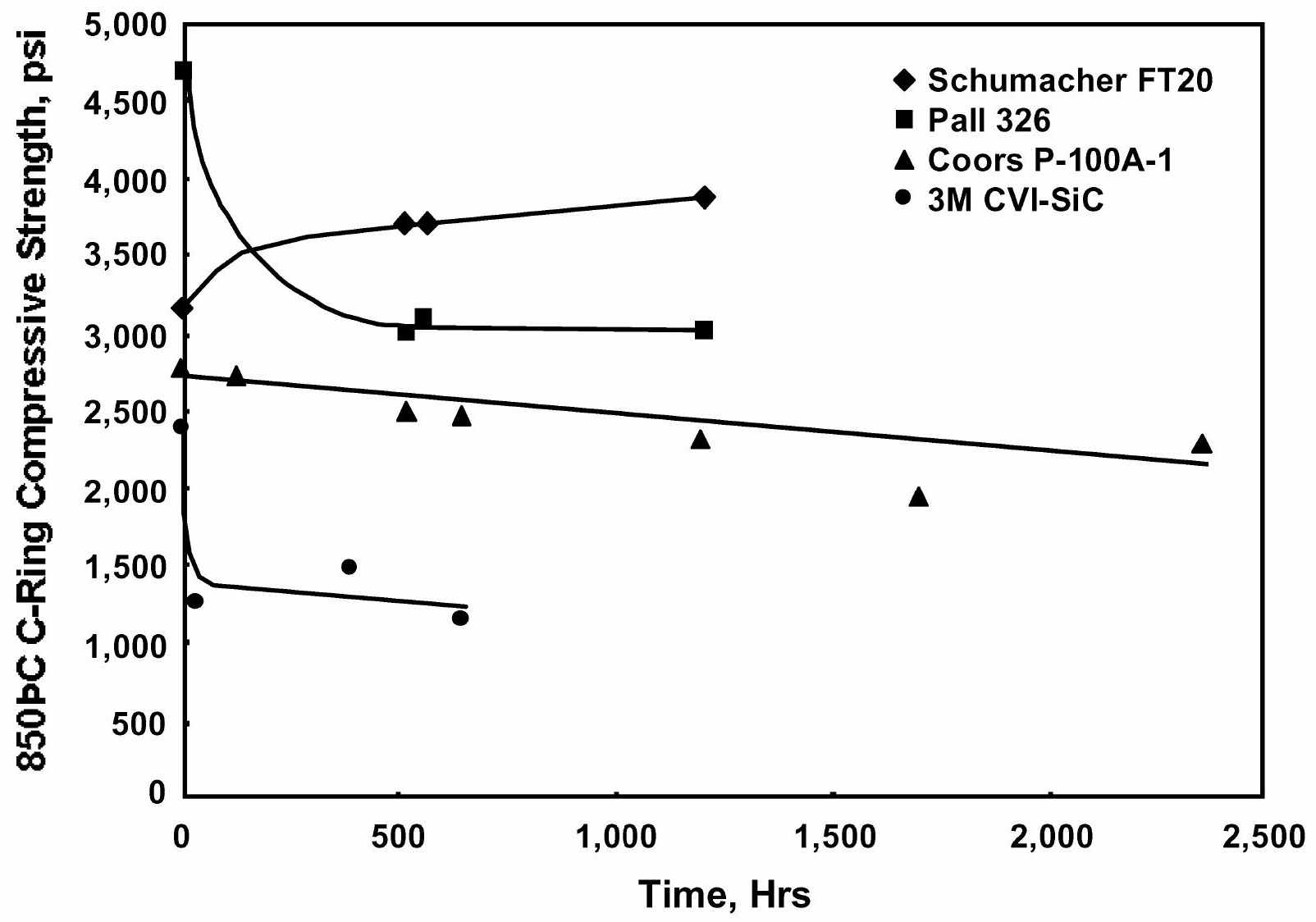

Figure 7 - Residual process temperature compressive strength of the PCFBC-exposed candle filters. 


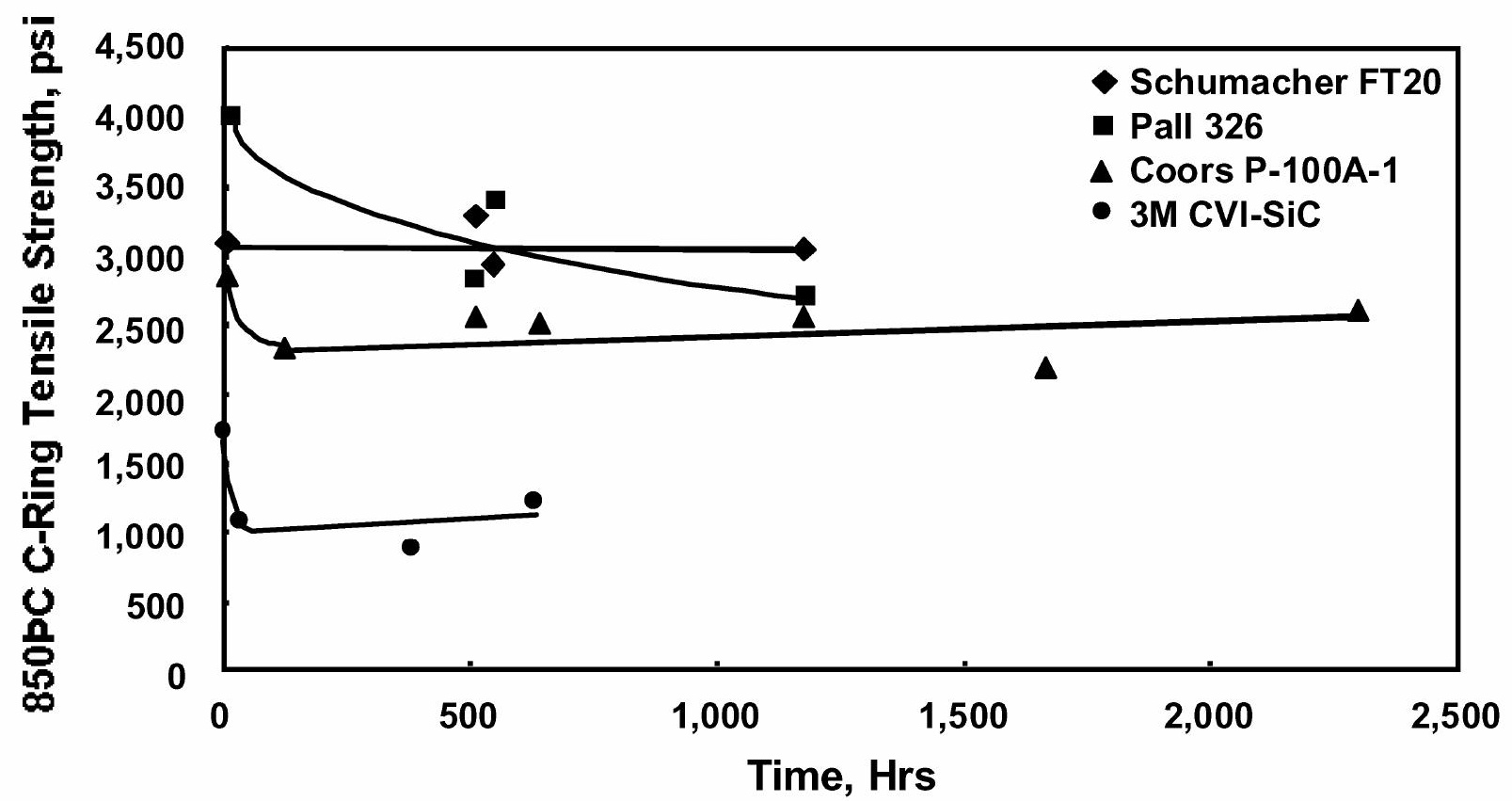

Figure 8 - Residual process temperature tensile strength of the PCFBC-exposed candle filters. 


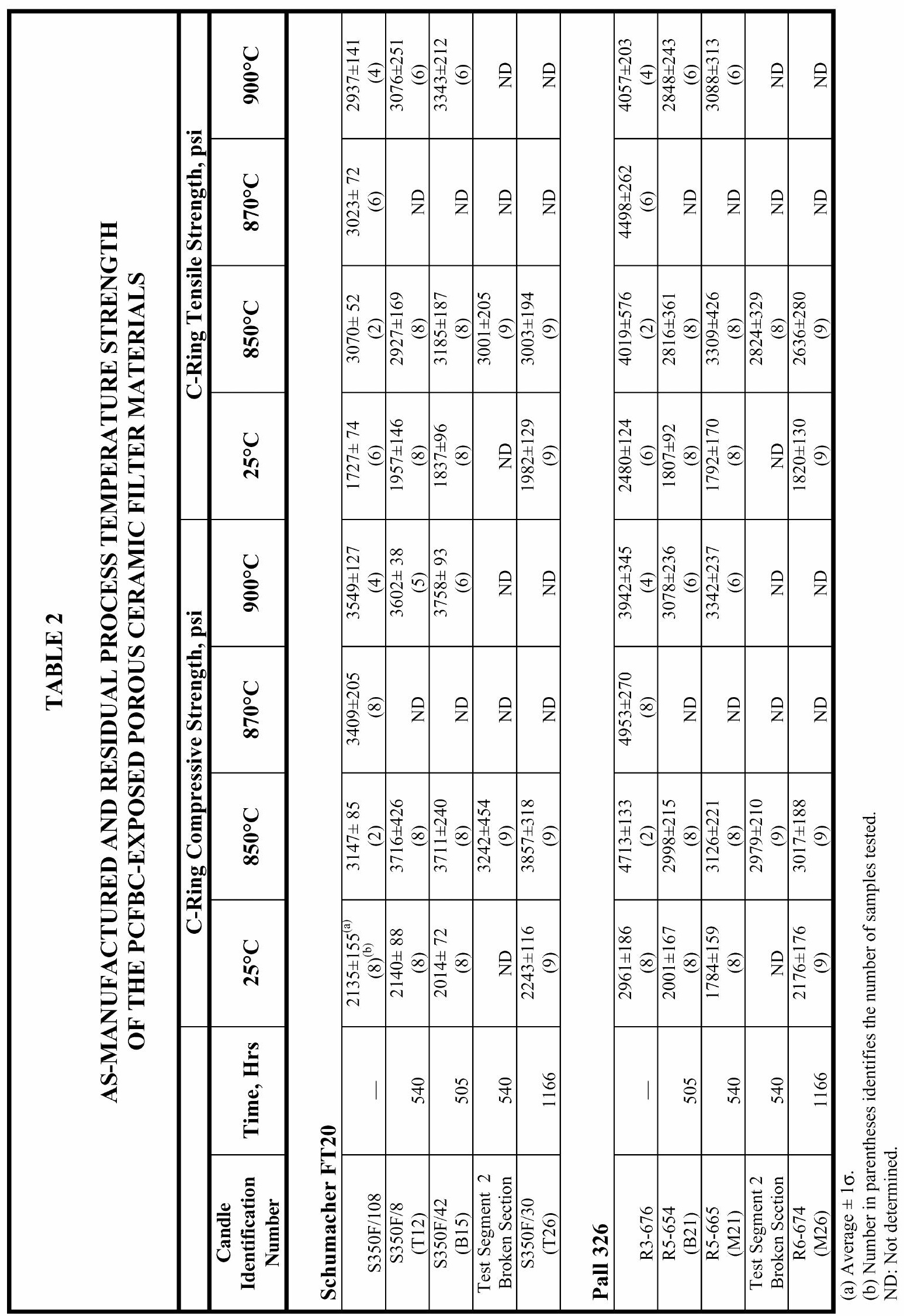




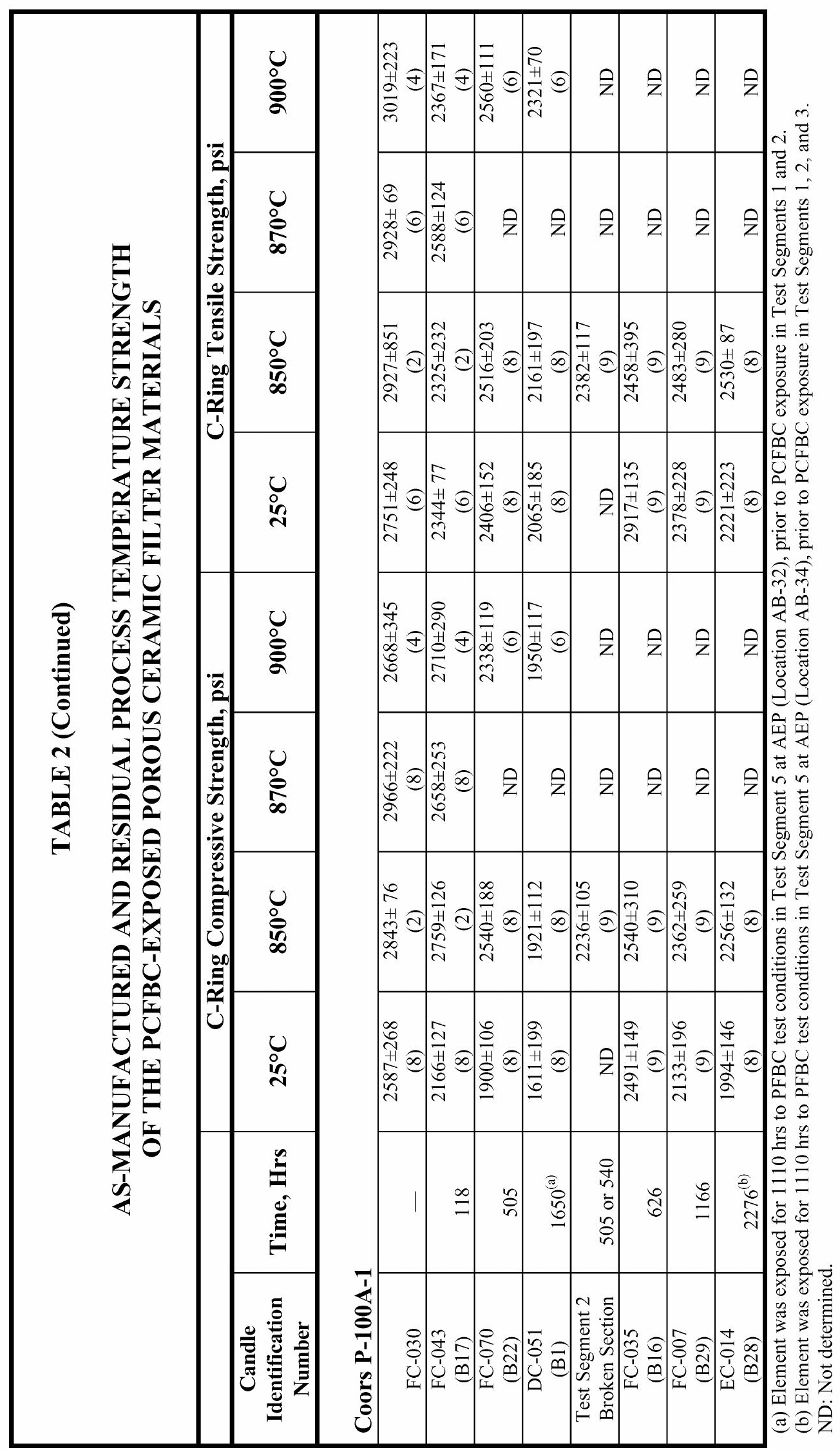




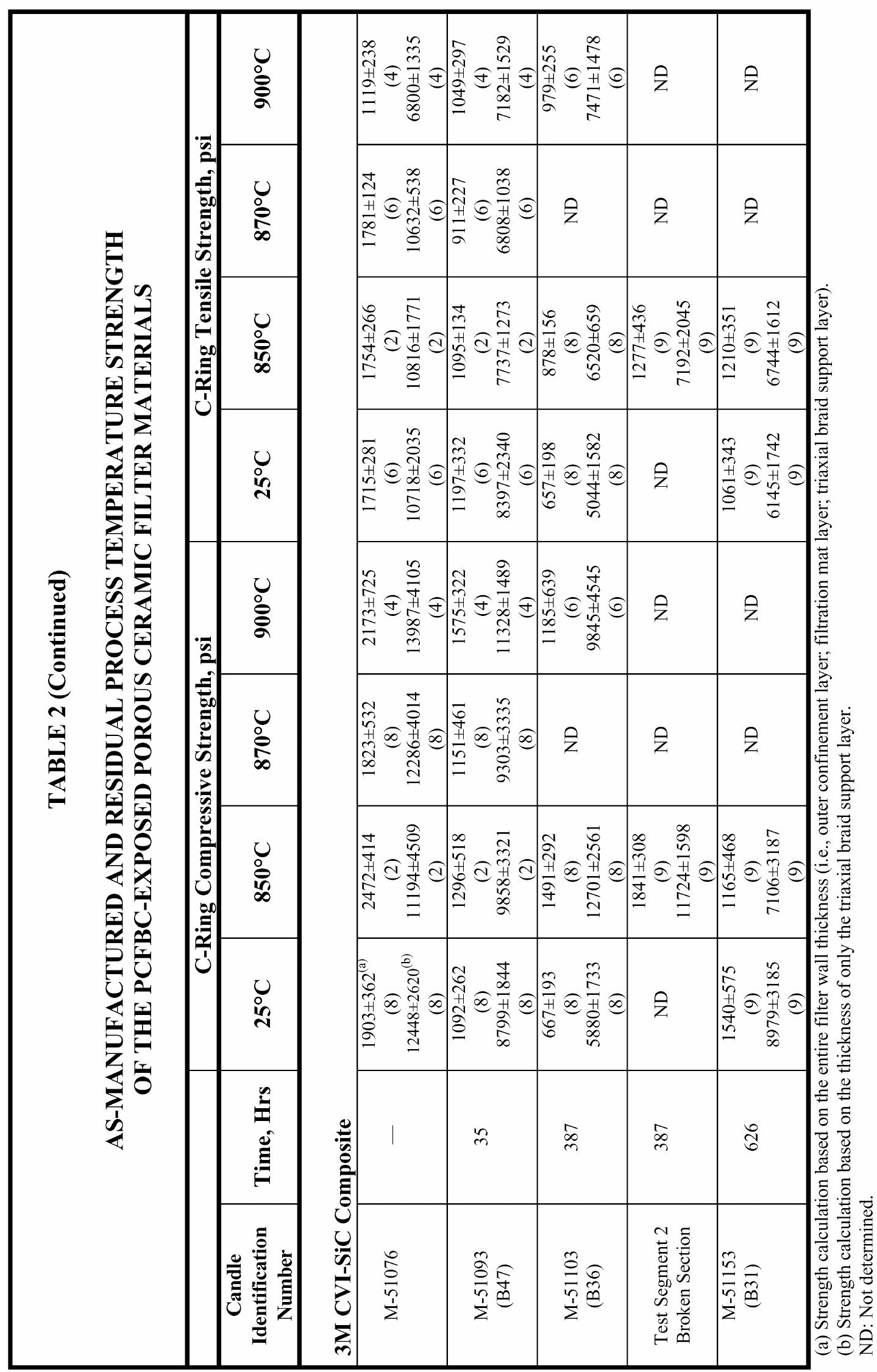




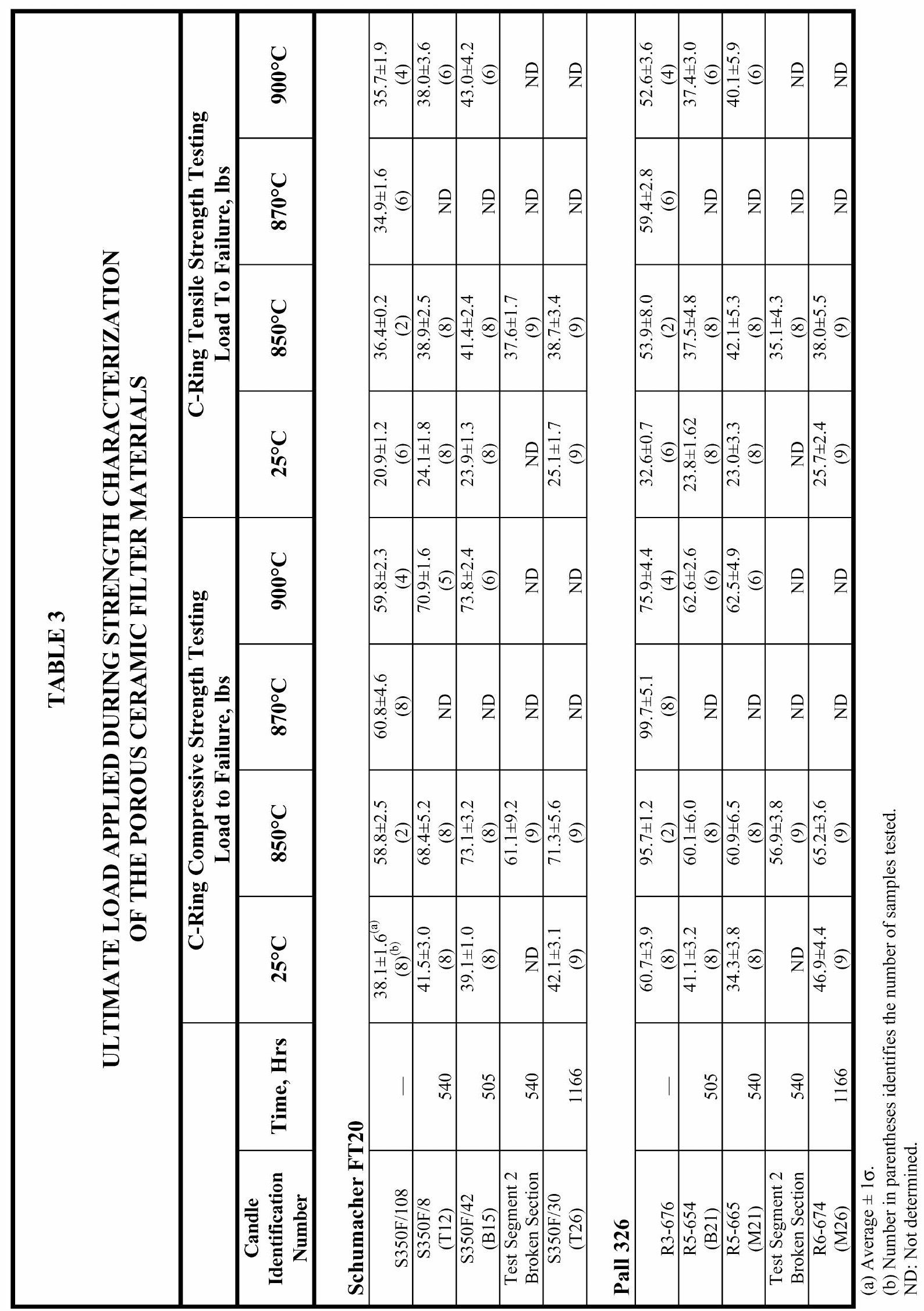




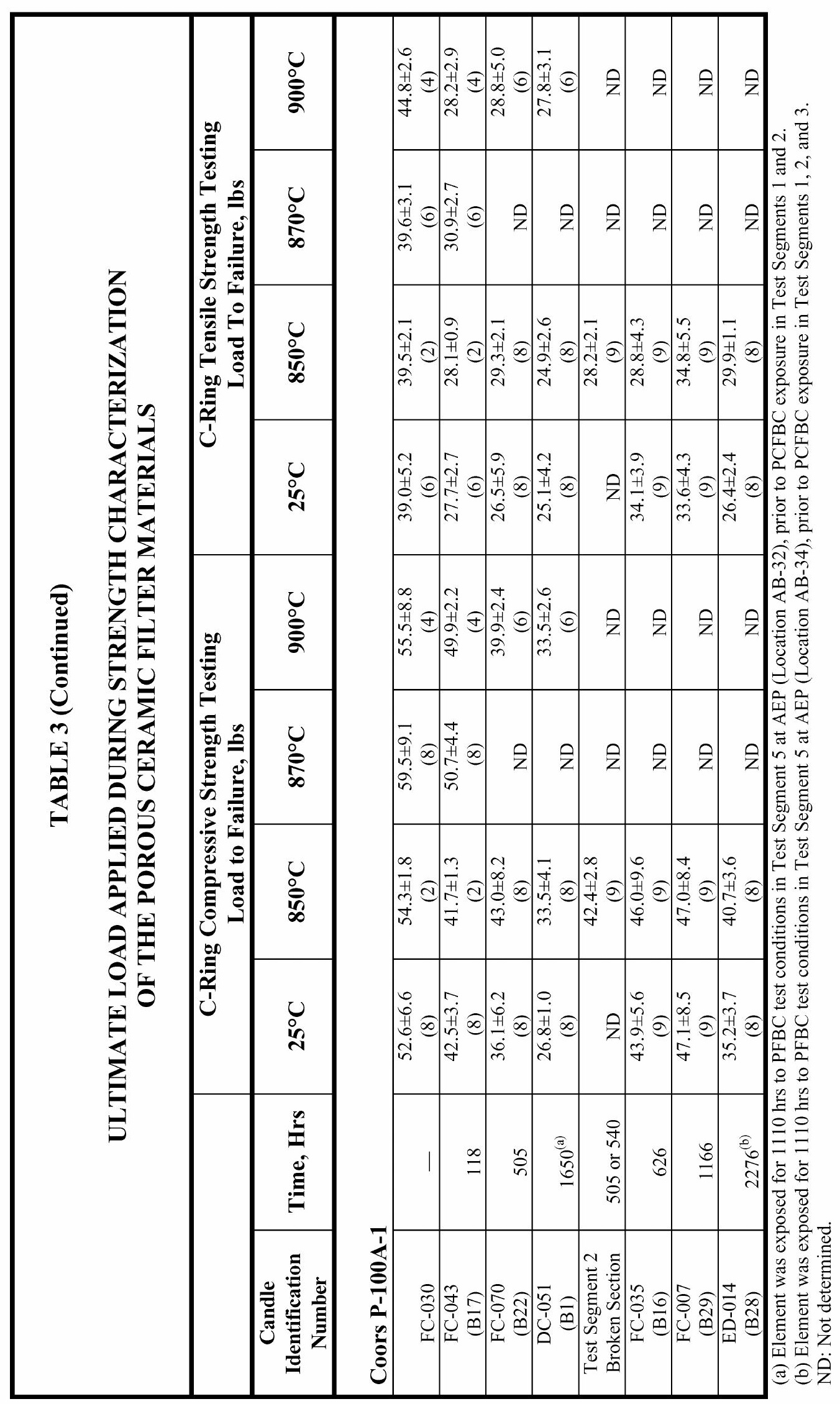




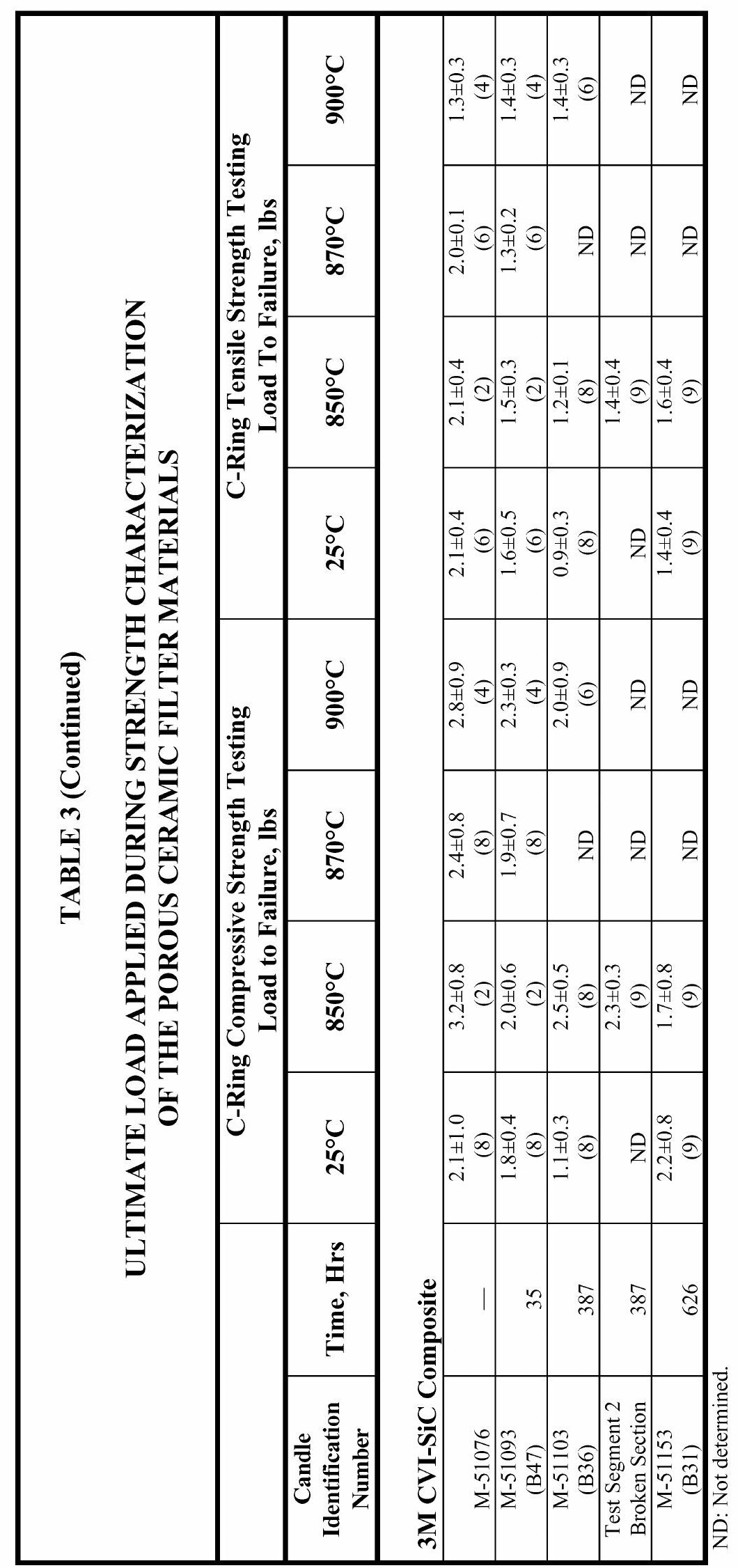


up to temperatures of $900^{\circ} \mathrm{C}$ (Table 4). In contrast, the as-manufactured Pall 326 filter matrix retained its brittle fracture characteristics up to temperatures of $850^{\circ} \mathrm{C}$, but experienced plastic deformation at temperatures of $870^{\circ} \mathrm{C}$ and $900^{\circ} \mathrm{C}$. The composite fracture characteristics of the as-manufactured $3 \mathrm{M} \mathrm{CVI-SiC}$ filter matrix were retained at all test temperatures.

After 1166 hours operation in the PCFBC environment, the c-ring compressive and tensile strengths of the Schumacher Dia Schumalith FT20 matrix tended to increase. In contrast the Pall 326 matrix initially experienced a loss of bulk matrix c-ring compressive and tensile strength, but achieved a conditioned compressive strength with extended process operation. ${ }^{3}$ The Coors P-100A-1 alumina/mullite matrix tended to gradually lose c-ring compressive strength as reflected by both the PCFBC-exposed and PFBC Tidd-exposed filter elements. In contrast, an initial loss of c-ring tensile strength resulted, followed by a conditioning and gradual increase in bulk strength of the Coors P-100A-1 alumina/mullite filter matrix. The 3M CVI-SiC composite matrix initially experienced a loss of c-ring compressive and tensile strength, followed by a conditioning or stabilization of the matrix during extended process operation.

Although operation in the PCFBC environment led to changes in the bulk strength of each porous ceramic filter matrix, a conditioned compressive or tensile strength of 1000-3500 psi was sufficient for continued operational viability of the commercially available monolithic and second generation fiber reinforced candle filters in advanced coal-fired applications.

\section{Hoop Stress, Elastic Modulus, and Poisson's Ratio}

A $254 \mathrm{~mm}$ (10 inch) section of material was removed from each of the Test Segment 2 and Test Segment 3 PCFBC-exposed surveillance candle filters. Two $90^{\circ}$ strain gage rosettes were installed along both inside and outside surfaces of the filter sections, at approximately the center of each test sample. A water filled bladder was inserted into the i.d. bore of each filter section, and was subsequently pressurized to determine the ultimate hoop strength of the filter material. The outer strain gage measurements for the 3M CVI-SiC composite filter material were somewhat in question, since delamination and shear were expected to have resulted between the layers of the composite structure during burst testing.

The pressure required to fail each filter section, the ultimate hoop stress, elastic modulus, and Poisson's ratio for the PCFBC-exposed surveillance filter sections are presented in Table 5. Also included in Table 5 are similar material properties for the as-manufactured filter materials.

\section{High Temperature Creep}

High temperature creep testing was conducted on $115 \mathrm{~mm} \times 8.5 \mathrm{~mm} \times 12 \mathrm{~mm}$ bars that were removed from the 540 hour, PCFBC-exposed, Schumacher Dia Schumalith FT20 and Pall 326 candle filters. As shown in Figure 9, the Schumacher Dia Schumalith FT20 and Pall 326 filter materials unlike the Schumacher Dia Schumalith F40 and Pall Vitropore 442T filter materials, did not exhibit high temperature creep when a 500 psi, 4-point bend, flexural load was applied to the surface of the bend bars for a period of $\sim 300-500$ hours at temperatures of $843^{\circ} \mathrm{C} .{ }^{4}$

\footnotetext{
${ }^{3}$ A conditioned strength identifies a constant residual porous ceramic filter matrix strength as a result of operation in the PCFBC environment. ${ }^{4}$ High temperature, bench-scale creep testing was typically conducted in air in a clam-shell furnace. During field operation, the filter matrix was exposed to the process gas environment which contained steam. The impact of steam, as well as alternate process gas phase constituents on high temperature creep strain and possibly the candle filter elongation mechanism(s) need to be determined.
} 


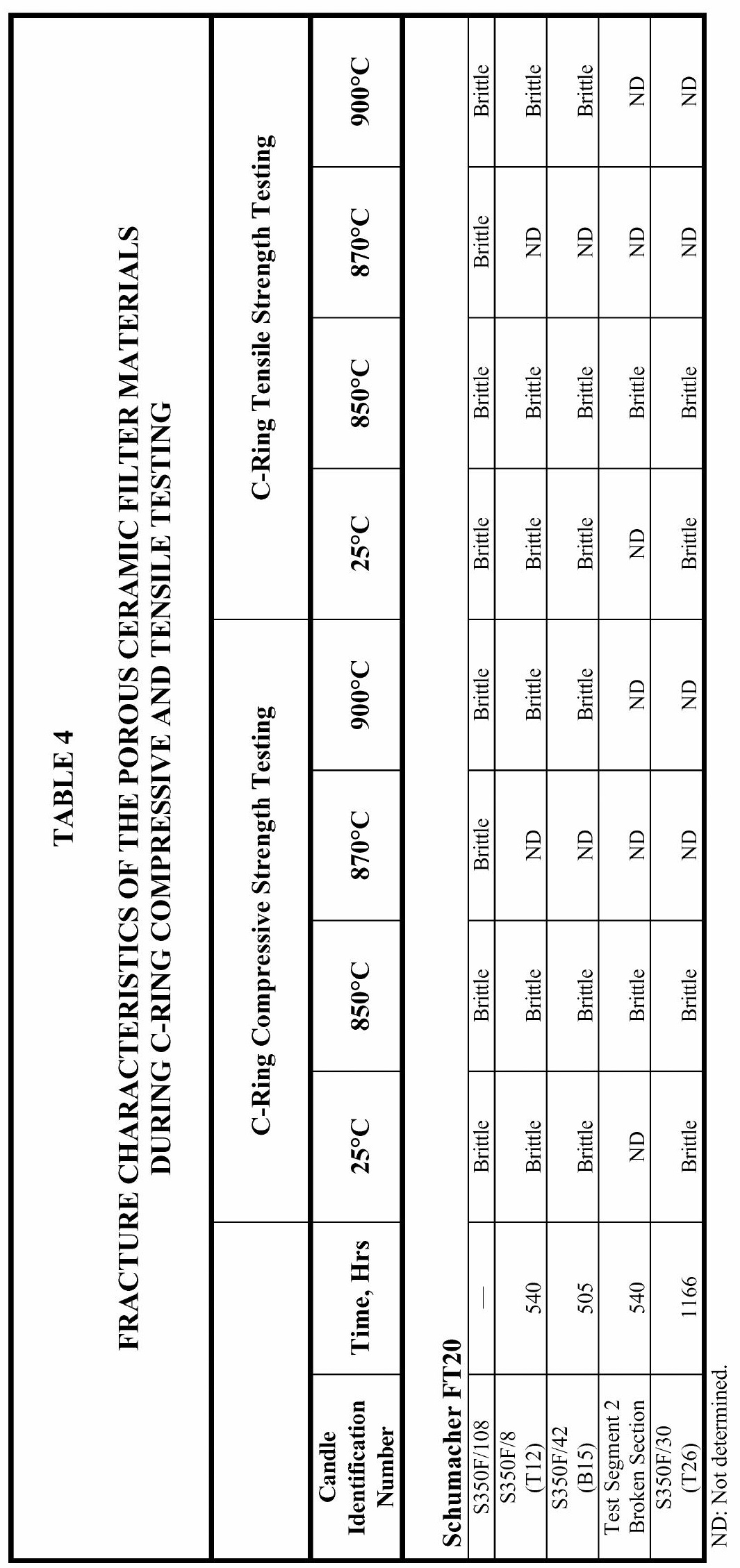




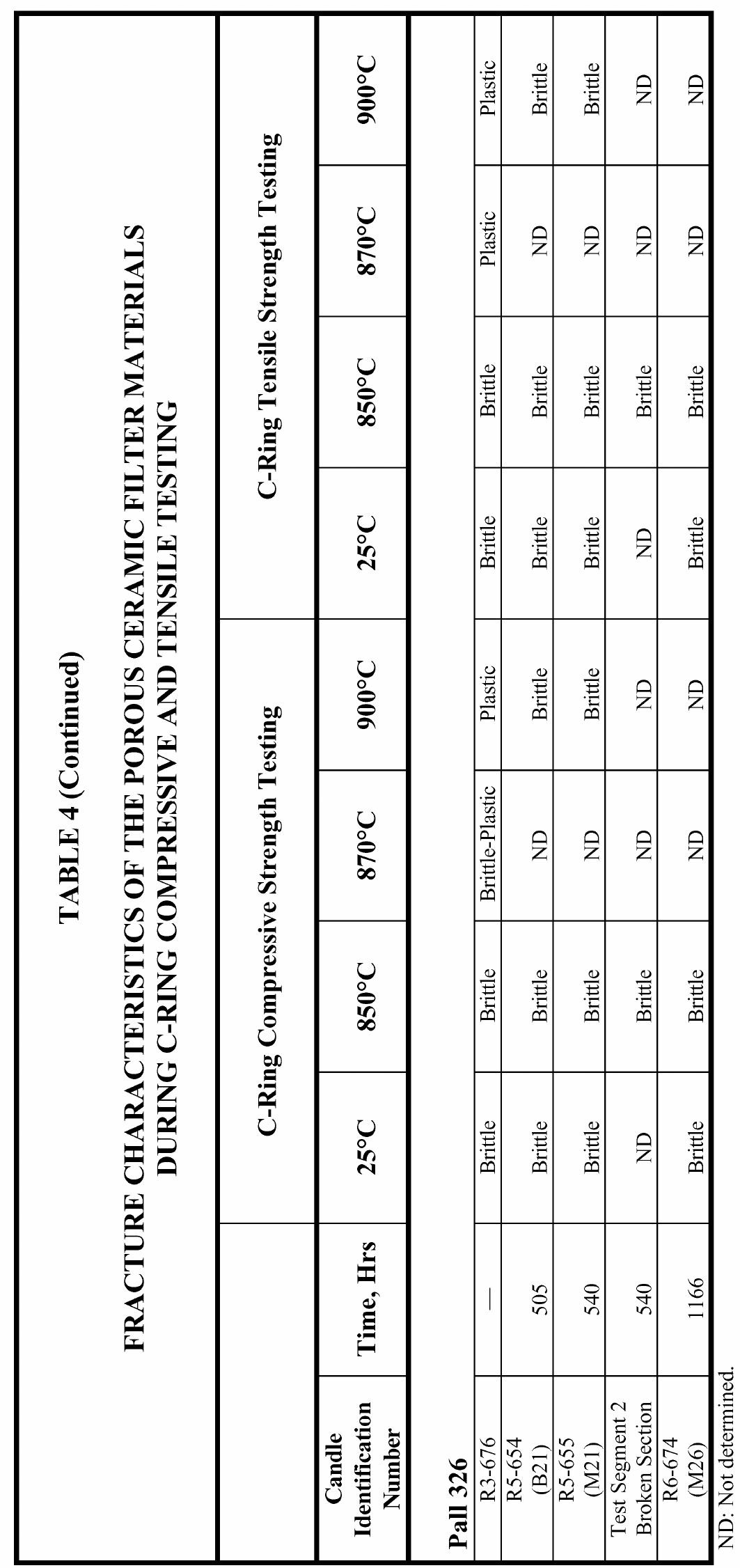




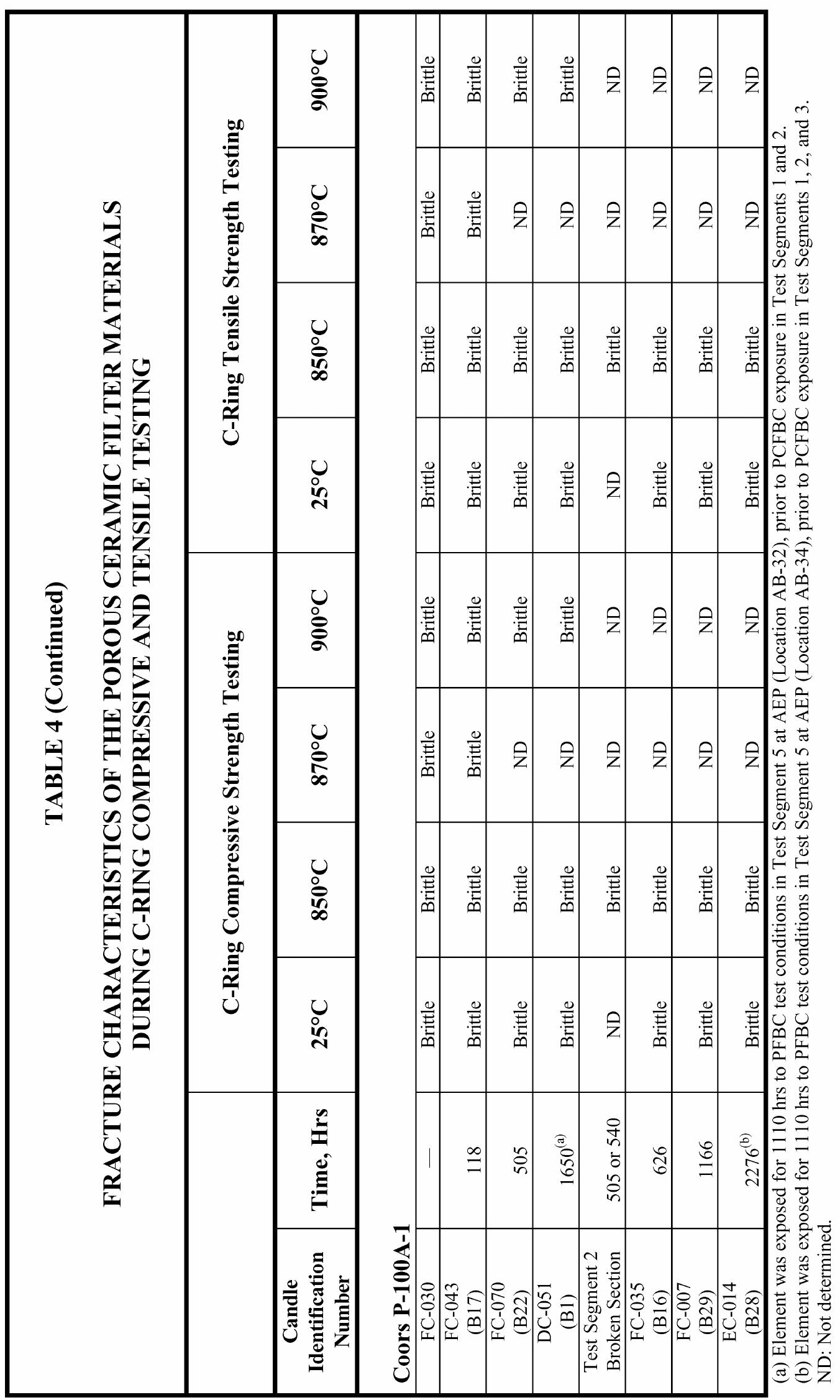




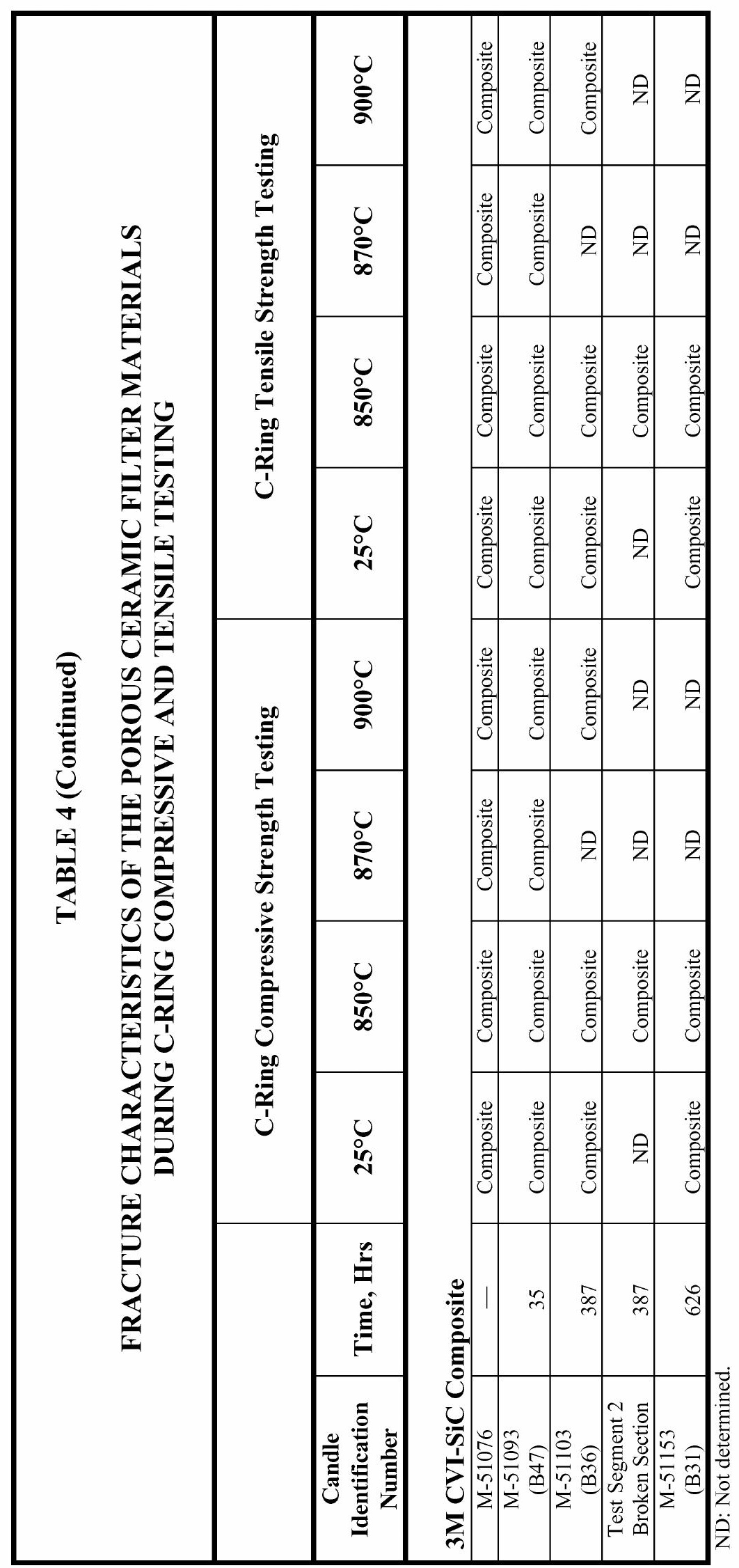




\section{TABLE 5}

\section{MATERIAL PROPERTIES OF THE PCFBC-EXPOSED POROUS CERAMIC CANDLE FILTERS}

-Test Segments 2 and 3 -

\begin{tabular}{c|c|c|c|c|c|}
\hline $\begin{array}{c}\text { Candle } \\
\text { Identification } \\
\text { Number }\end{array}$ & $\begin{array}{c}\text { Opurst } \\
\text { Time, Hrs }\end{array}$ & $\begin{array}{c}\text { Pressure, } \\
\text { psi }\end{array}$ & $\begin{array}{c}\text { Ultimate Hoop } \\
\text { Stress, psi }\end{array}$ & $\begin{array}{c}\text { Modulus, } \\
\text { psi x 10 10 }\end{array}$ & Poisson's Ratio \\
\hline
\end{tabular}

Schumacher Dia Schumalith FT20

\begin{tabular}{|c|c|c|c|c|c|}
\hline $\mathrm{S} 350 \mathrm{~F} / 108$ & - & 665 & 1703 & 7.3 & 0.17 \\
\hline $\mathrm{S} 350 \mathrm{~F} / 8(\mathrm{~T} 12)$ & 540 & 555 & 1496 & 7.44 & 0.21 \\
\hline $\mathrm{S} 350 \mathrm{~F} / 42(\mathrm{~B} 15)$ & 505 & 590 & 1584 & 7.39 & 0.15 \\
\hline $\mathrm{S} 350 \mathrm{~F} / 30(\mathrm{~T} 26)$ & 1166 & 720 & 1942 & 5.77 & 0.11 \\
\hline
\end{tabular}

Pall 326

\begin{tabular}{|c|c|c|c|c|c|}
\hline R3-676 & - & ND & ND & ND & ND \\
\hline R5-655 (M21) & 540 & 525 & 1369 & 5.00 & 0.16 \\
\hline R5-654 (B21) & 505 & 520 & 1344 & 5.15 & 0.16 \\
\hline R6-674 (M26) & 1166 & 650 & 1641 & 4.83 & 0.13 \\
\hline
\end{tabular}

Coors P-100A-1 Alumina/Mullite

\begin{tabular}{|c|c|c|c|c|c|}
\hline FC-030 & - & 860 & 2317 & 5.7 & 0.23 \\
\hline FC-070 (B22) & 505 & 540 & 1503 & 4.84 & 0.21 \\
\hline DC-051 (B1) & $1650^{(\mathrm{a})}$ & 505 & 1373 & 5.18 & 0.20 \\
\hline FC-035 (B16) & 626 & 520 & 1425 & 3.90 & 0.18 \\
\hline FC-007 (B29) & 1166 & 565 & 1402 & 3.44 & 0.25 \\
\hline EC-014 (B28) & $2276^{(\mathrm{a})}$ & 505 & 1380 & 4.37 & 0.24 \\
\hline
\end{tabular}

3M CVI-SiC Composite

\begin{tabular}{|c|c|c|c|c|c|}
\hline M-51076 & - & ND & $1.01 \mathrm{ksi}$ & $2.96-3.38$ & $0.14-0.27$ \\
\hline $\mathrm{M}-51103(\mathrm{~B} 36)$ & 387 & 133 & 1179 & 3.35 & 0.22 \\
\hline $\mathrm{M}-51153(\mathrm{~B} 31)$ & 626 & 105 & 946 & 5.59 & 0.34 \\
\hline
\end{tabular}

ND: Not determined.

(a) PFBC/PCFBC-exposed candle filter. 


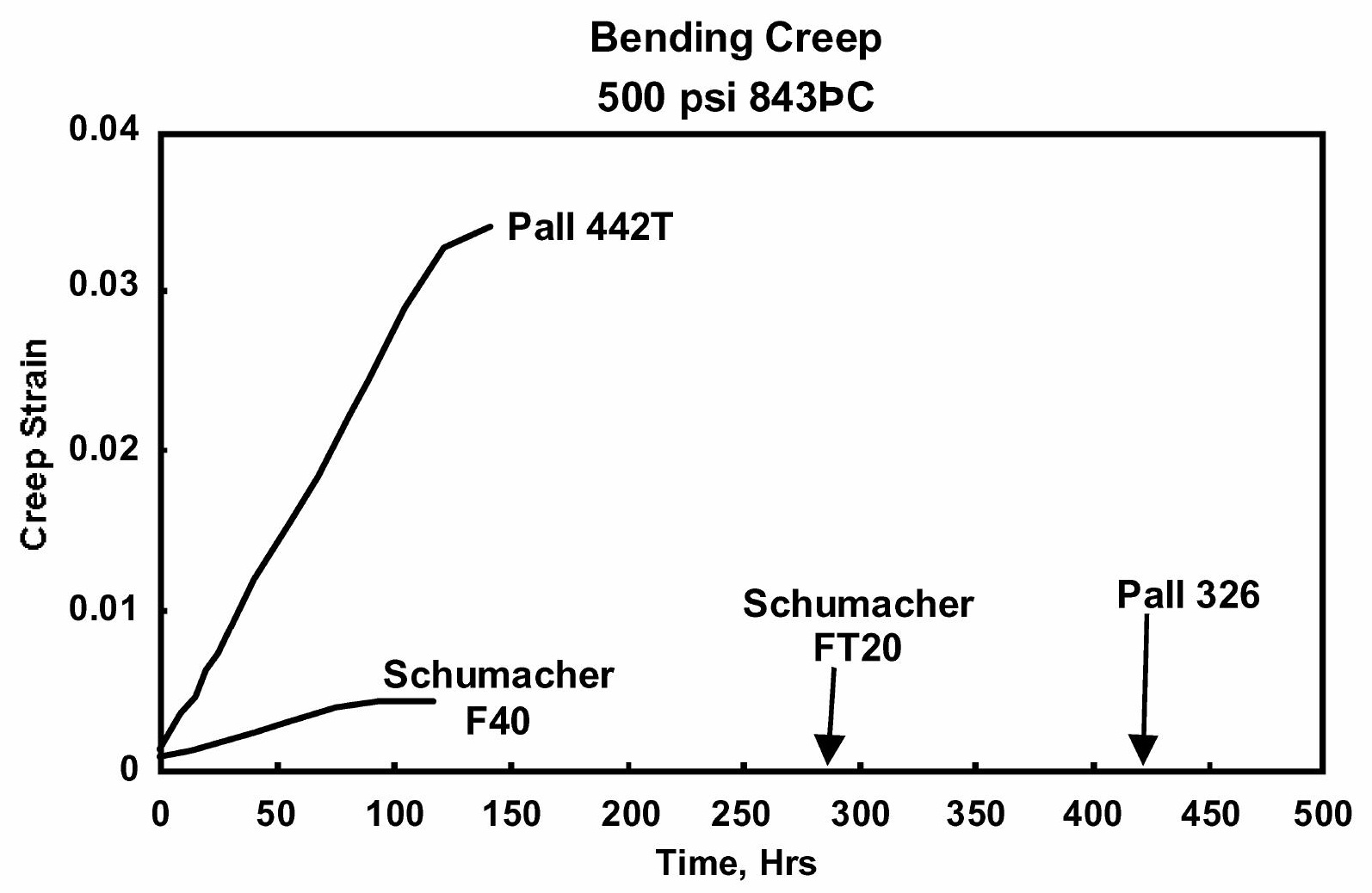

Schumacher Dia Schumalith F40 (S418/312B): 3038 Hrs, $732^{\circ} \mathrm{C} \mathrm{PFBC}$

Schumacher Dia Schumalith FT20 (S350F/8): $540 \mathrm{Hrs}, 850^{\circ} \mathrm{C} \mathrm{PCFBC}$

Pall Vitropore $442 \mathrm{~T}$ (R3-86): $1341 \mathrm{Hrs}, 830^{\circ} \mathrm{C}$ PCFBC

Pall 326 (R5-665): $540 \mathrm{Hrs}, 850^{\circ} \mathrm{C}$ PCFBC

Figure 9 - High temperature creep strain of the field-tested clay bonded silicon carbide filter materials as a function of time. 
The enhanced high temperature creep resistance of the Schumacher Dia Schumalith FT20 and Pall 326 filter matrices resulted from manufacturing changes that had been made to the binder phase during production of both filter elements.

High temperature creep testing was similarly conducted on the 1166 hour, PCFBC-exposed, Schumacher Dia Schumalith FT20 and Pall 326 filter materials, and on the 2276 hour, PFBC/PCFBC Coors P-100A-1 alumina/mullite filter material. When a load of 500 psi was applied to the surface of the bend bars, virtually no or negligible creep strain was identified after $\sim 500$ hours (Table 6).

Similar high temperature creep testing was conducted using the 387 hour, PCFBC-exposed, 3M CVI-SiC composite filter material. Although delamination of the triaxial braid from the filtration mat and outer confinement layers resulted, testing indicated that the $3 \mathrm{M} \mathrm{CVI-SiC} \mathrm{composite} \mathrm{matrix} \mathrm{did} \mathrm{not}$ exhibit creep strain after $\sim 300-500$ hours when a 500 psi, 4-point bend, flexural load was applied to the material at temperatures of $843^{\circ} \mathrm{C}$.

\section{Thermal Expansion}

Sections of the PCFBC-exposed Schumacher Dia Schumalith FT20 and Pall 326 filter materials were subjected to thermal expansion testing. As shown in Table 7, and Figures 10 and 11, the thermal expansion of the PCFBC-exposed Schumacher and Pall filter materials was nearly identical. Similarly the thermal expansion of the PCFBC-exposed clay bonded silicon carbide filter materials was nearly identical to that of the as-manufactured Coors P-100A-1 alumina/mullite and Schumacher Dia Schumalith F40 filter matrices.

\section{Microstructural Analysis}

In order to determine whether microstructural changes occurred within the filter matrices as a result of operation in the PCFBC process gas environment, sections of material were removed from each filter element at the conclusion of Test Segment 2 and Test Segment 3. Each section was fresh fractured and subjected to scanning electron microscopy/ energy dispersive $\mathrm{x}$-ray analysis (SEM/EDAX). Characterization of each matrix was conducted along the outer membrane surface, pulse cycled surface, and throughout the cross-sectioned wall of the PCFBC-exposed filter elements.

In addition to information pertaining to the microstructure of each PCFBC-exposed filter element, SEM/EDAX analyses were utilized to determine the location of the ash and sorbent fines within the various filter materials. These analyses indicated that ash or sorbent fines were retained along the outer surface of the Schumacher Dia Schumalith FT20 and Pall 326 monolithic filter elements, with limited penetration into the barrier filter membrane. Penetration of fines was similarly limited to the first pore layers of the monolithic Coors P-100A-1 alumina/mullite filter elements. In contrast, fines were detected within the filtration mat of the $3 \mathrm{M} \mathrm{CVI-SiC} \mathrm{composite} \mathrm{candles.} \mathrm{During} \mathrm{pulse} \mathrm{cycling,}$ penetration of material (i.e., ash/sorbent fines after failure of an element; oxidation or metal wastage of structural components downstream of the filter array) typically to depths of 1-2 mm into each filter matrix resulted along the i.d. bore of the monolithic candles. 


\begin{tabular}{|c|c|c|c|c|c|c|c|c|}
\hline \multicolumn{9}{|c|}{$\begin{array}{c}\text { TABLE } 6 \\
\text { IIGH TEMPERATURE CREEP STRAIN }\end{array}$} \\
\hline \multirow[b]{2}{*}{ Filter Material } & \multicolumn{2}{|c|}{ АЕР-PFBC } & \multicolumn{2}{|c|}{ FW-PCFBC } & \multicolumn{3}{|c|}{ HT Creep Testing } & \multirow{2}{*}{$\begin{array}{c}\begin{array}{c}\text { Total Creep } \\
\text { Strain }\end{array} \\
\text { Percent }\end{array}$} \\
\hline & Hrs & $\begin{array}{c}\text { Temp, } \\
{ }^{\circ} \mathrm{C}\end{array}$ & Hrs & $\begin{array}{c}\text { Temp. } \\
{ }^{\circ} \mathrm{C}\end{array}$ & $\begin{array}{l}\text { Load, } \\
\text { psi }\end{array}$ & $\begin{array}{c}\text { Temp, } \\
{ }^{\circ} \mathrm{C}\end{array}$ & Hrs & \\
\hline $\begin{array}{l}\text { Schumacher Dia } \\
\text { Schumalith F40 }\end{array}$ & - & - & - & - & 500 & 843 & $18-53$ & $1.47-2.03^{(\mathrm{a})}$ \\
\hline $\begin{array}{l}\text { Schumacher Dia } \\
\text { Schumalith F40 }\end{array}$ & 3038 & 732 & - & - & 500 & 843 & 114 & 0.42 \\
\hline $\begin{array}{c}\text { Schumacher Dia } \\
\text { Schumalith FT20 }\end{array}$ & - & - & - & - & 500 & 843 & 300 & $0.085^{(a)}$ \\
\hline $\begin{array}{l}\text { Schumacher Dia } \\
\text { Schumalith FT20 }\end{array}$ & - & - & 540 & 850 & 500 & 843 & 500 & 0 \\
\hline $\begin{array}{l}\text { Schumacher Dia } \\
\text { Schumalith FT20 }\end{array}$ & - & - & 1166 & 850 & 500 & 850 & 510 & 0.038 \\
\hline Pall Vitropore $442 \mathrm{~T}$ & - & - & - & - & 500 & 843 & 300 & $2.81^{(\mathrm{a})}$ \\
\hline Pall Vitropore 442T & - & - & 1341 & 830 & 500 & 843 & 141 & 3.41 \\
\hline Pall 326 & - & - & - & - & 500 & 850 & 500 & $0.085^{(\mathrm{a})}$ \\
\hline Pall 326 & - & - & 540 & 850 & 500 & 850 & 500 & 0 \\
\hline Pall 326 & - & - & 1166 & 850 & 500 & 843 & 510 & 0 \\
\hline $\begin{array}{l}\text { Coors P-100A-1 } \\
\text { Alumina/Mullite }\end{array}$ & - & - & $2276^{(\mathrm{b})}$ & 850 & 500 & 850 & 510 & 0.019 \\
\hline
\end{tabular}

(a) Significantly reduced creep strain for the high temperature creep resistant Schumacher Dia Schumalith FT20 and Pall 326 filter materials in comparison to the Schumacher Dia Schumalith F40 and Pall Vitropore 442T filter materials.

(b) PFBC/PCFBC-exposed filter element. 
TABLE 7

THERMAL EXPANSION AS A FUNCTION OF TEMPERATURE - ASTM E-228 -

\section{Schumacher FT20 (T12) ${ }^{(a)}$}

\begin{tabular}{|c|c|c|c|}
\hline $\begin{array}{c}\text { Temperature, } \\
\mathbf{}^{\mathbf{C}}\end{array}$ & $\begin{array}{c}\text { Expansion, } \\
\mathbf{\%}\end{array}$ & $\begin{array}{c}\text { Average Alpha, } \\
\mathbf{1 0}^{-6} /{ }^{\circ} \mathbf{C}\end{array}$ & $\begin{array}{c}\text { Instantaneous Alpha, } \\
\mathbf{1 0}^{-6} /{ }^{\circ} \mathbf{C}\end{array}$ \\
\hline 25 & 0.000 & 0.000 & 4.978 \\
\hline 50 & 0.012 & 4.978 & 4.717 \\
\hline 100 & 0.035 & 4.717 & 5.304 \\
\hline 200 & 0.092 & 5.258 & 5.726 \\
\hline 300 & 0.150 & 5.451 & 5.235 \\
\hline 400 & 0.197 & 5.245 & 4.802 \\
\hline 500 & 0.246 & 5.177 & 4.750 \\
\hline 600 & 0.292 & 5.073 & 4.578 \\
\hline 700 & 0.339 & 5.020 & 4.711 \\
\hline 800 & 0.389 & 5.014 & 4.981 \\
\hline 900 & 0.442 & 5.054 & 5.363 \\
\hline
\end{tabular}

Pall $326\left(\right.$ M21) ${ }^{(\text {a) }}$

\begin{tabular}{|c|c|c|c|}
\hline $\begin{array}{c}\text { Temperature, } \\
{ }^{\mathbf{0}} \mathbf{C}\end{array}$ & $\begin{array}{c}\text { Expansion, } \\
\mathbf{\%}\end{array}$ & $\begin{array}{c}\text { Average Alpha, } \\
\mathbf{1 0}^{-\mathbf{6}} /{ }^{\circ} \mathbf{C}\end{array}$ & $\begin{array}{c}\text { Instantaneous Alpha, } \\
\mathbf{1 0}^{-6} /{ }^{\circ} \mathbf{C}\end{array}$ \\
\hline 25 & 0.000 & 0.000 & 5.970 \\
\hline 50 & 0.015 & 5.970 & 4.882 \\
\hline 100 & 0.037 & 4.882 & 5.222 \\
\hline 200 & 0.093 & 5.328 & 5.974 \\
\hline 300 & 0.156 & 5.676 & 5.297 \\
\hline 400 & 0.199 & 5.312 & 4.677 \\
\hline 500 & 0.250 & 5.256 & 4.937 \\
\hline 600 & 0.298 & 5.181 & 4.769 \\
\hline 700 & 0.345 & 5.111 & 4.784 \\
\hline 800 & 0.394 & 5.079 & 5.048 \\
\hline 900 & 0.446 & 5.097 & 5.239 \\
\hline
\end{tabular}

(a) Initial sample length $=2.015$ in.

Sample length after testing $=2.015$ in.

Heating/cooling rate $=2^{\circ} \mathrm{C} / \mathrm{min}$. 


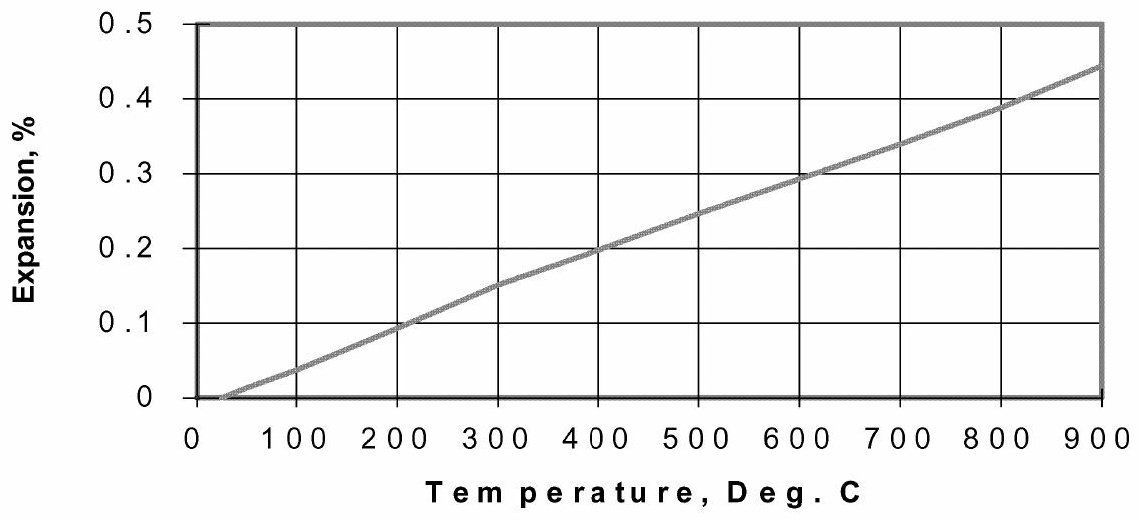

Figure 10 - Thermal expansion of the PCFBC-exposed Schumacher Dia Schumalith FT20 filter matrix (S350F/8 (T12); $540 \mathrm{hrs).}$

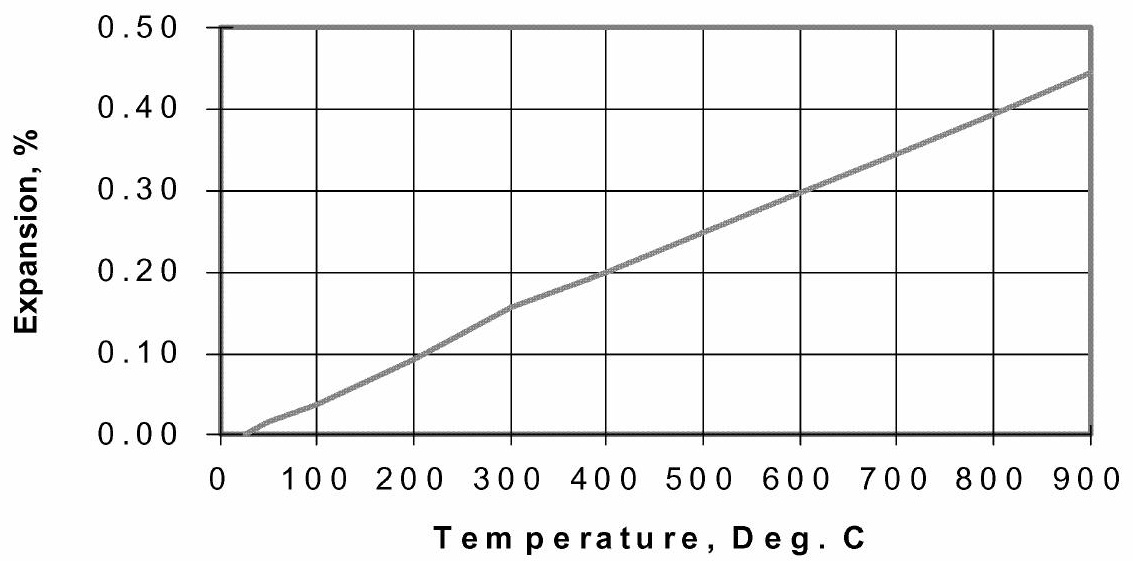

Figure 11 - Thermal expansion of the PCFBC-exposed Pall 326 filter matrix (R5-665 (M21); $540 \mathrm{hrs}$ ). 


\section{$\underline{\text { Schumacher Dia Schumalith FT20 Candle Filters }}$}

The as-manufactured, $10 \mathrm{~mm}$ thick structural support wall of the monolithic Schumacher Dia Schumalith FT20 filter matrix consisted of silicon carbide grains that were bonded together via a high temperature creep resistant binder. An $\sim 100 \mu \mathrm{m}$ thick membrane layer was applied to the outer surface of each filter element. The membrane consisted of ceramically bonded alumina fibers, as well as fine silicon carbide grit.

Extensive crystallization of the high temperature creep resistant Schumacher Dia Schumalith FT20 filter matrix occurred after 540 hours of operation in the $850^{\circ} \mathrm{C}$ PCFBC environment (Figure 12). Negligible changes were detected within the fibrous outer membrane.

In contrast after 1166 hours of operation in the PCFBC environment, an amorphous or melt-like phase resulted along the surface of the silicon carbide grains in the support matrix near the o.d. surface of the filter element (Figures 13 and 14). At the center of the cross-sectioned filter wall and i.d. surface, extensive crystallization of the coating that encapsulated the silicon carbide grains was evident (Figures 15-17). Although the binder-containing elements (i.e., aluminum, potassium, and sodium) were typically present within the silicon-oxygen-enriched layer that encapsulated the silicon carbide grains in the Schumacher Dia Schumalith FT20 filter matrix, in several areas, the concentration of these elements was relatively low. This implied that oxidation of the silicon carbide grains resulted, leading to the formation of $\mathrm{SiO}_{2}$, and subsequently a reduction in the concentration of the original binder-containing elements within the layer that encapsulated the support grains.

\section{$\underline{\text { Pall } 326 \text { Candle Filters }}$}

Similar to the Schumacher Dia Schumalith FT20 candle filters, the as-manufactured monolithic Pall 326 barrier filters consisted of silicon carbide grains that were bonded together via a high temperature creep resistant binder. A finer grained silicon carbide layer was applied to the outer surface of the $10 \mathrm{~mm}$ structural support wall of each filter element, forming an external membrane.

Extensive crystallization of the high temperature creep resistant binder resulted within the Pall 326 filter matrix after 540 hours of operation in the $850^{\circ} \mathrm{C}$ PCFBC environment (Figure 18). Changes within the fine grained silicon carbide membrane tended to indicate the presence of silica, implying that oxidation of the grit most likely occurred.

After 1166 hours of operation in the PCFBC environment, the Pall 326 filter matrix experienced extensive crystallization throughout the filter wall (Figures 19-21). The crystallized outer coating that encapsulated the silicon carbide grains contained areas that were enriched primarily with silica, while alternate areas predominantly contained mullite-like rod formations. The thickness of the encapsulating layer that typically resulted along the surface of the Pall 326 PCFBC-exposed silicon carbide grains is shown in Figure 22. Crystallization along the outer surface, and through the $\sim 7 \mu \mathrm{m}$ coating was evident. Along alternate grains near the o.d. surface of the 1166 hour, PCFBC-exposed, Pall 326 filter element, an amorphous silica-enriched encapsulating layer was identified (Figure 23).

Along the i.d. or pulse cycled surface of the 1166 hour, PCFBC-exposed, Pall 326 filter element, extensive crystallization of the encapsulating shell that coated the silicon carbide grains was clearly evident (Figure 24). The melt-like features of the silica-enriched outer coating are shown at higher 

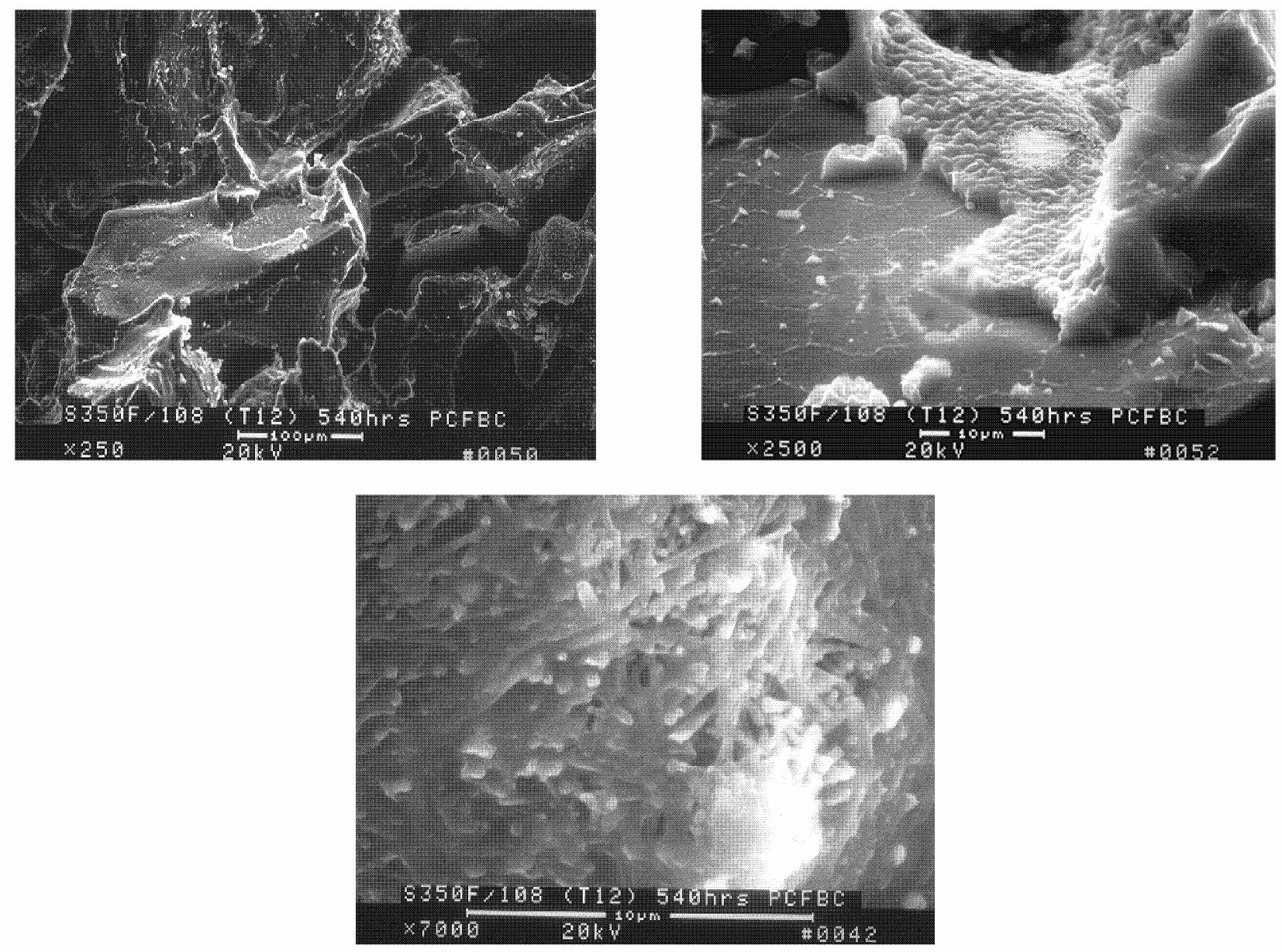

Figure 12 - Microstructure of the 540 hour, PCFBC-exposed, Schumacher Dia Schumalith FT20 filter matrix. 


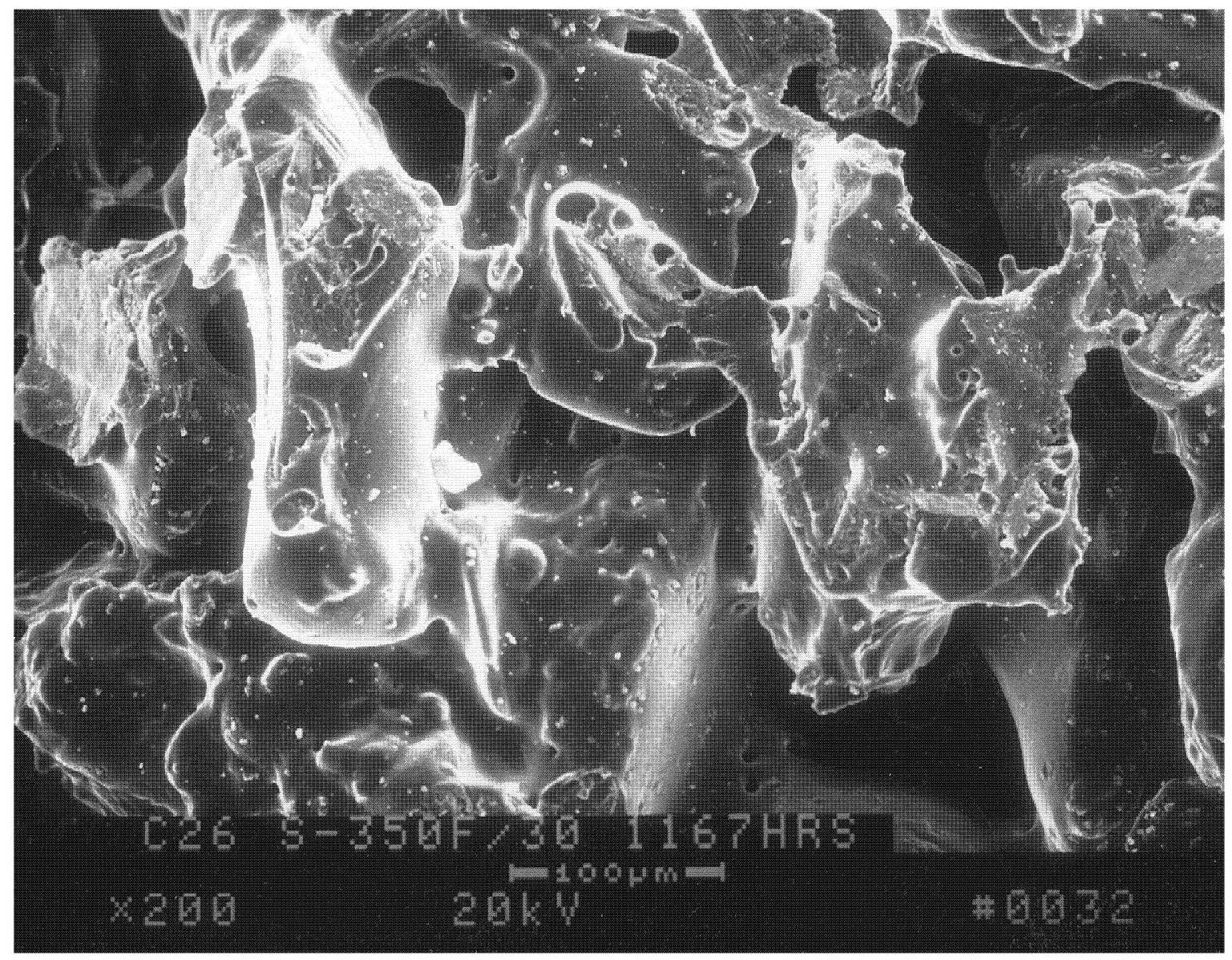

Figure 13 - Microstructure of the 1166 hour, PCFBC-exposed, Schumacher Dia Schumalith FT20 filter matrix near the outer surface of the filter element. 


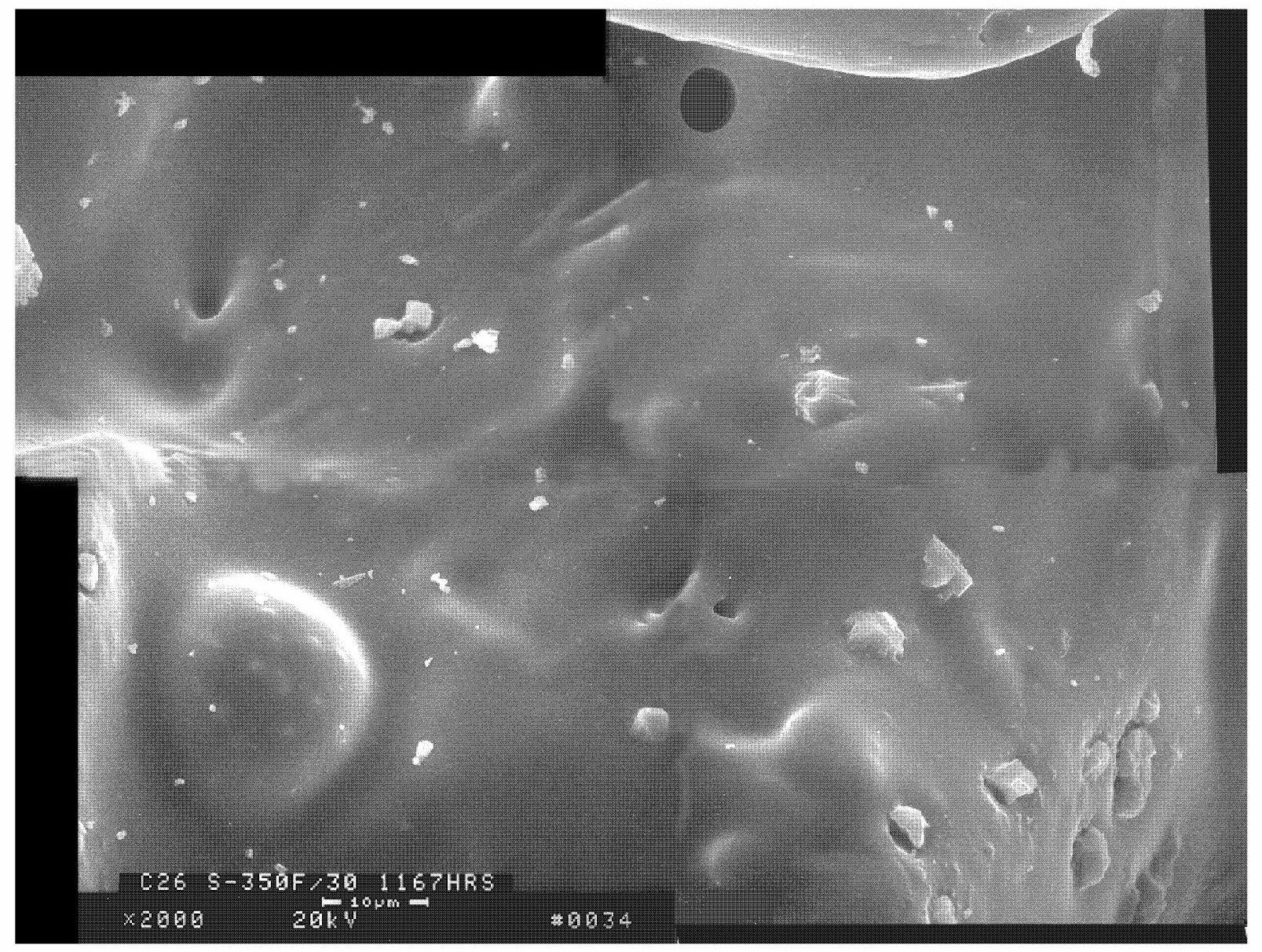

Figure 14 - Melt-like appearance of the coating that encapsulated the silicon carbide grains in the 1166 hour, PCFBC-exposed, Schumacher Dia Schumalith FT20 filter matrix near the outer surface of the filter element. 


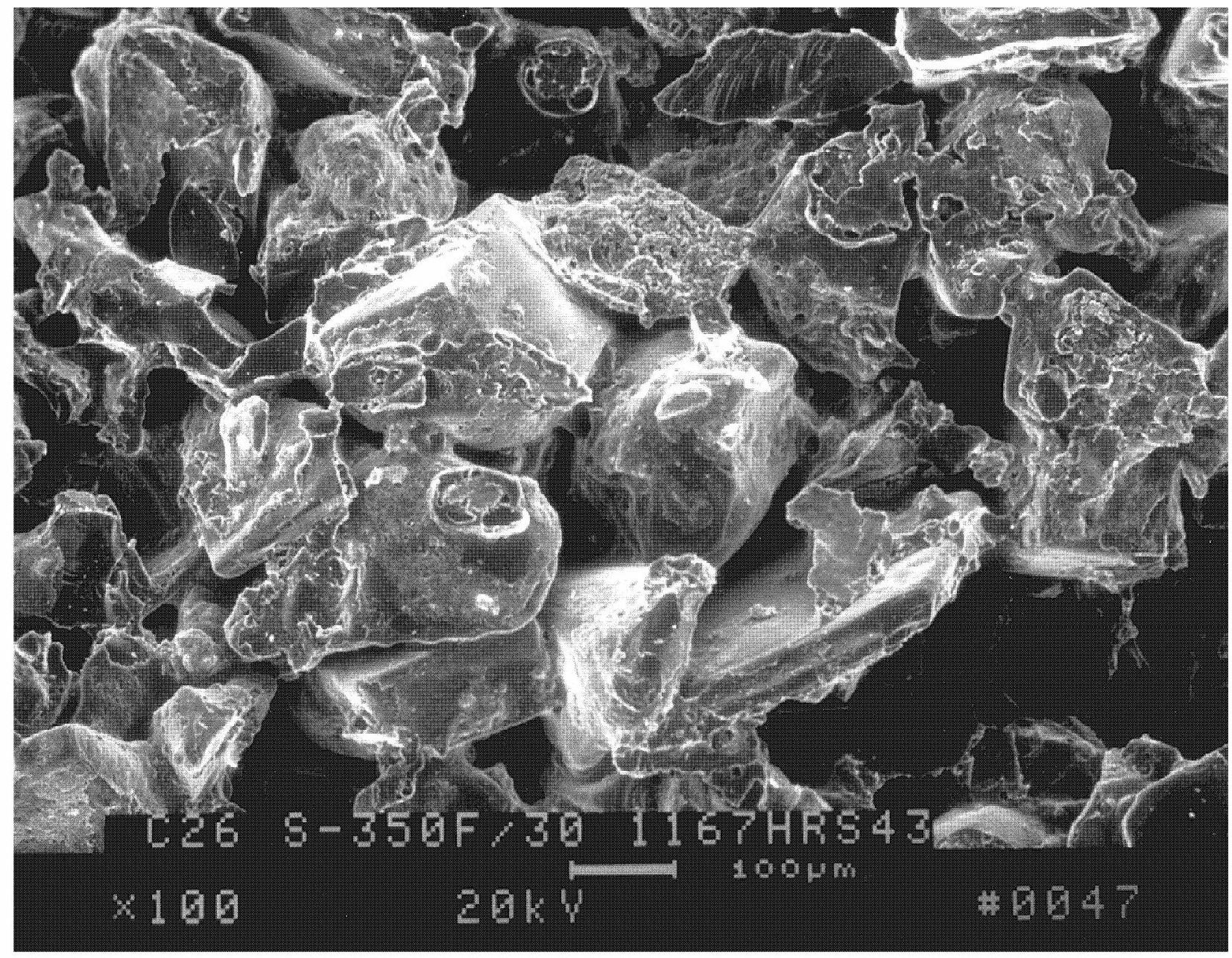

Figure 15 - Microstructure of the 1166 hour, PCFBC-exposed, Schumacher Dia Schumalith FT20 filter matrix near the center of the filter wall. 


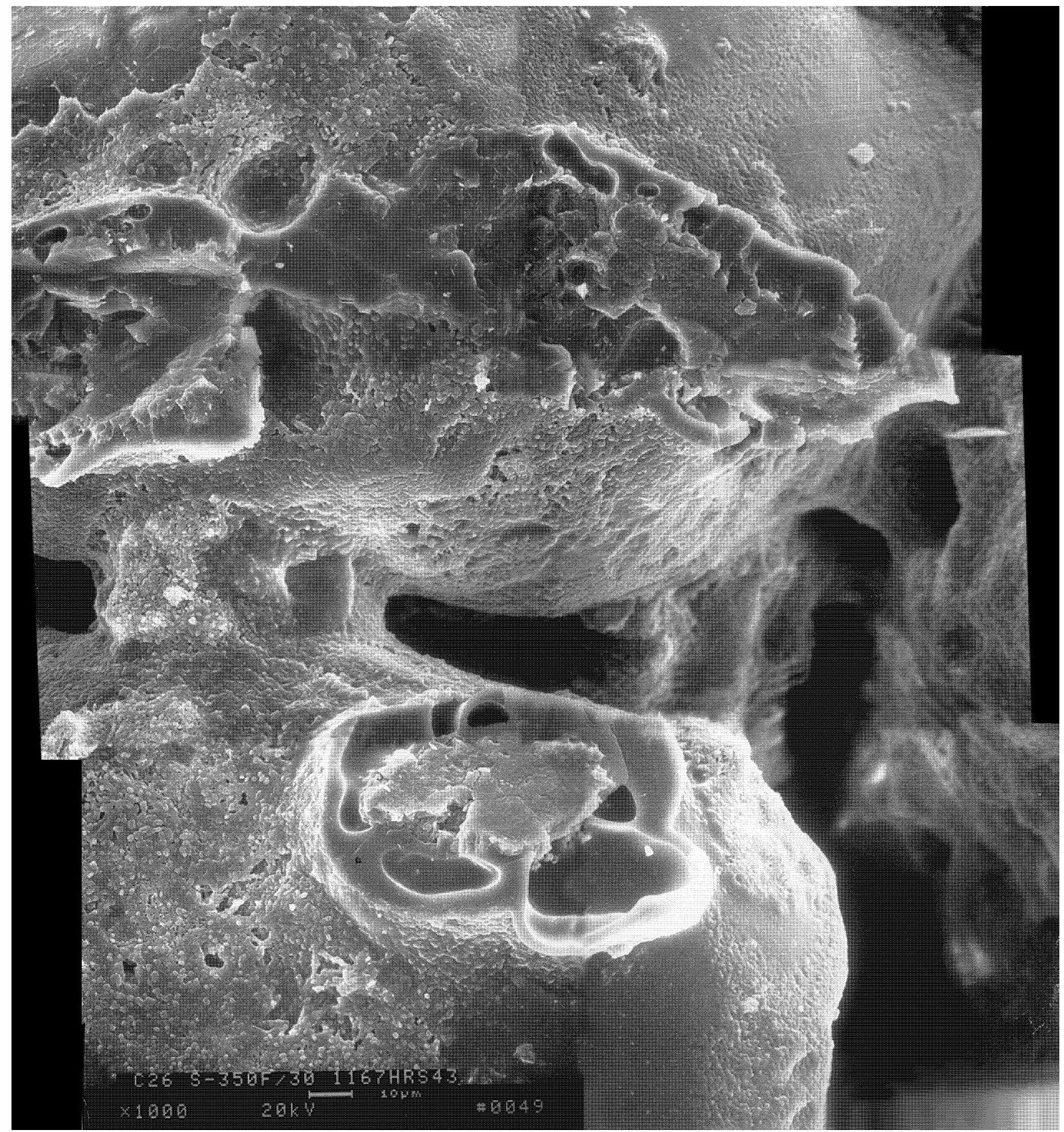

Figure 16 - Extensive crystallization that resulted along the coating that encapsulated the silicon carbide grains in the 1166 hour, PCFBC-exposed, Schumacher Dia Schumalith FT20 filter matrix near the center of the filter wall. 


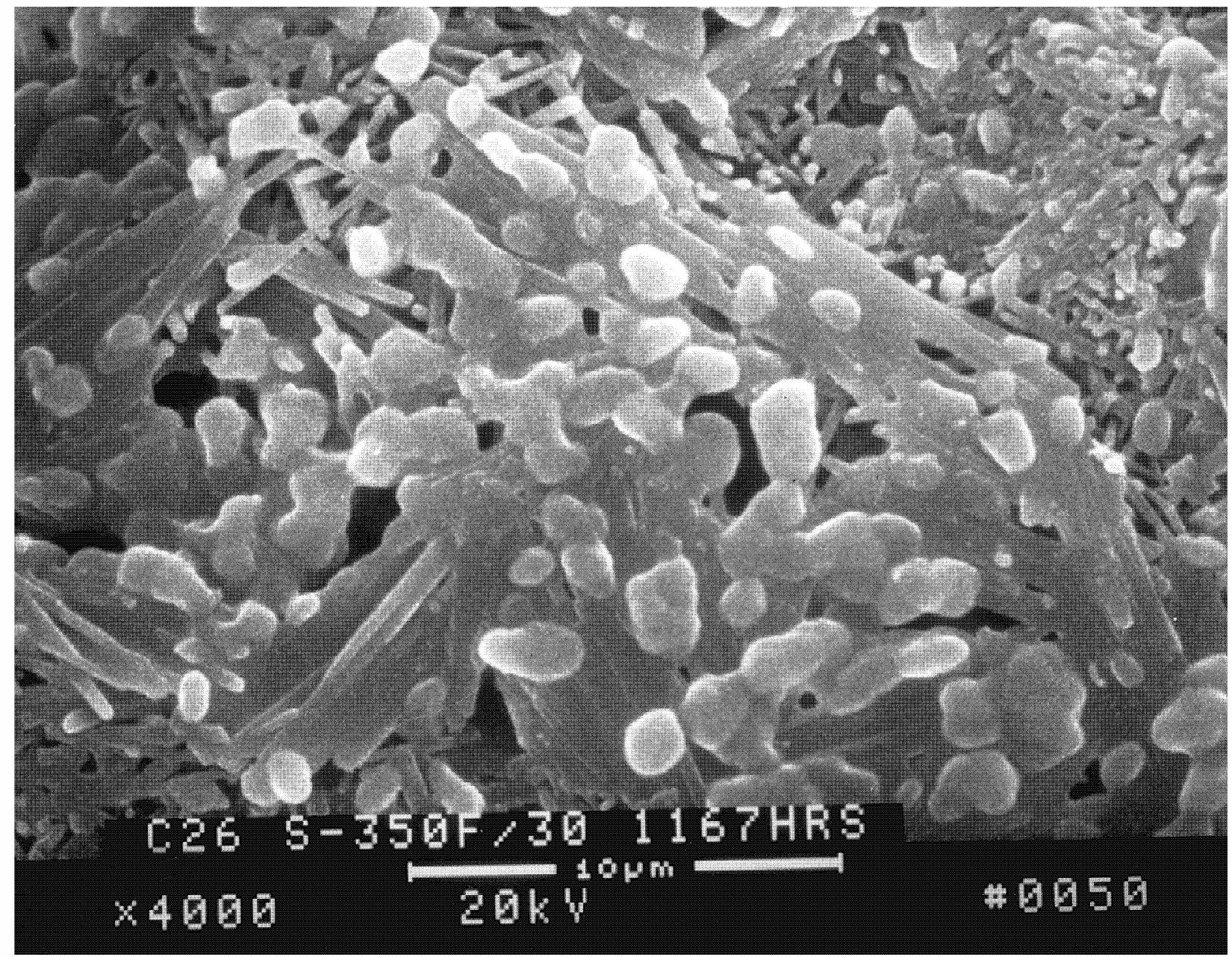

Figure 17 - Morphology of the mullite-enriched phase that encapsulated the 1166 hour, PCFBC exposed, silicon carbide grains in the Schumacher Dia Schumalith FT20 filter matrix near the center of the filter wall. 

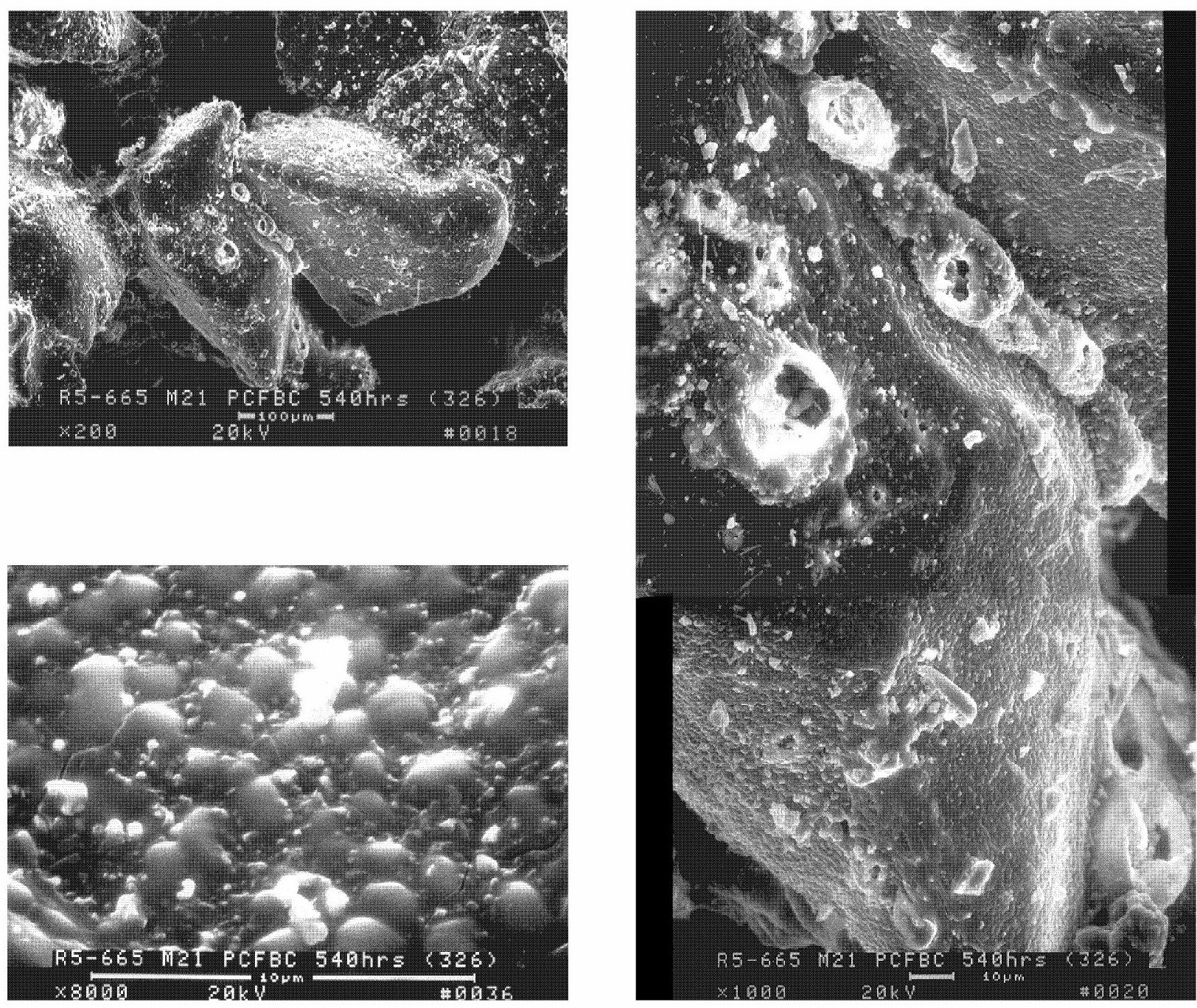

Figure 18 - Morphology of the 540 hour, PCFBC-exposed, Pall 326 filter matrix. 


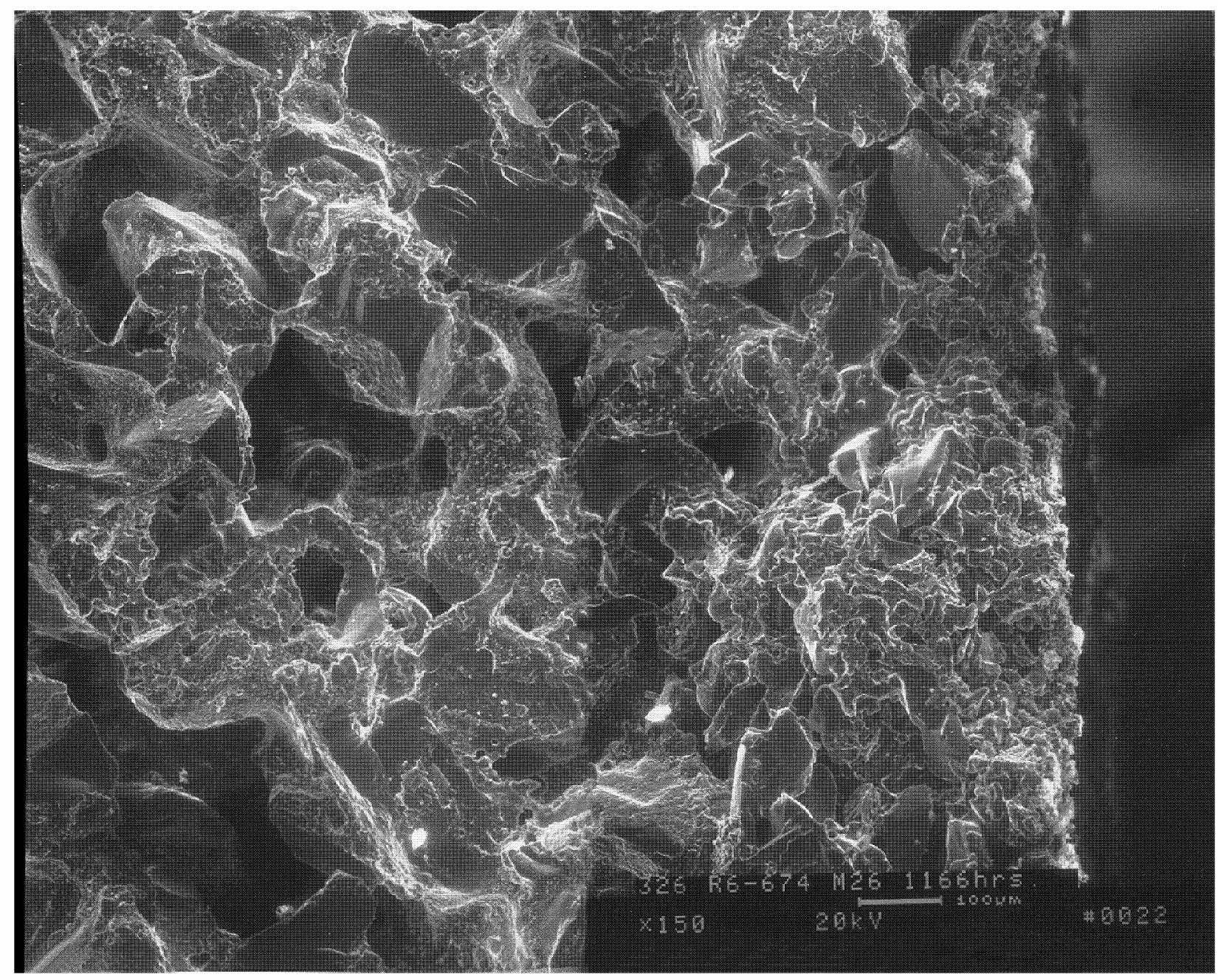

Figure 19 - Microstructure of the cross-sectioned, 1166 hour, PCFBC-exposed, Pall 326 filter matrix near the outer surface of the filter element. 


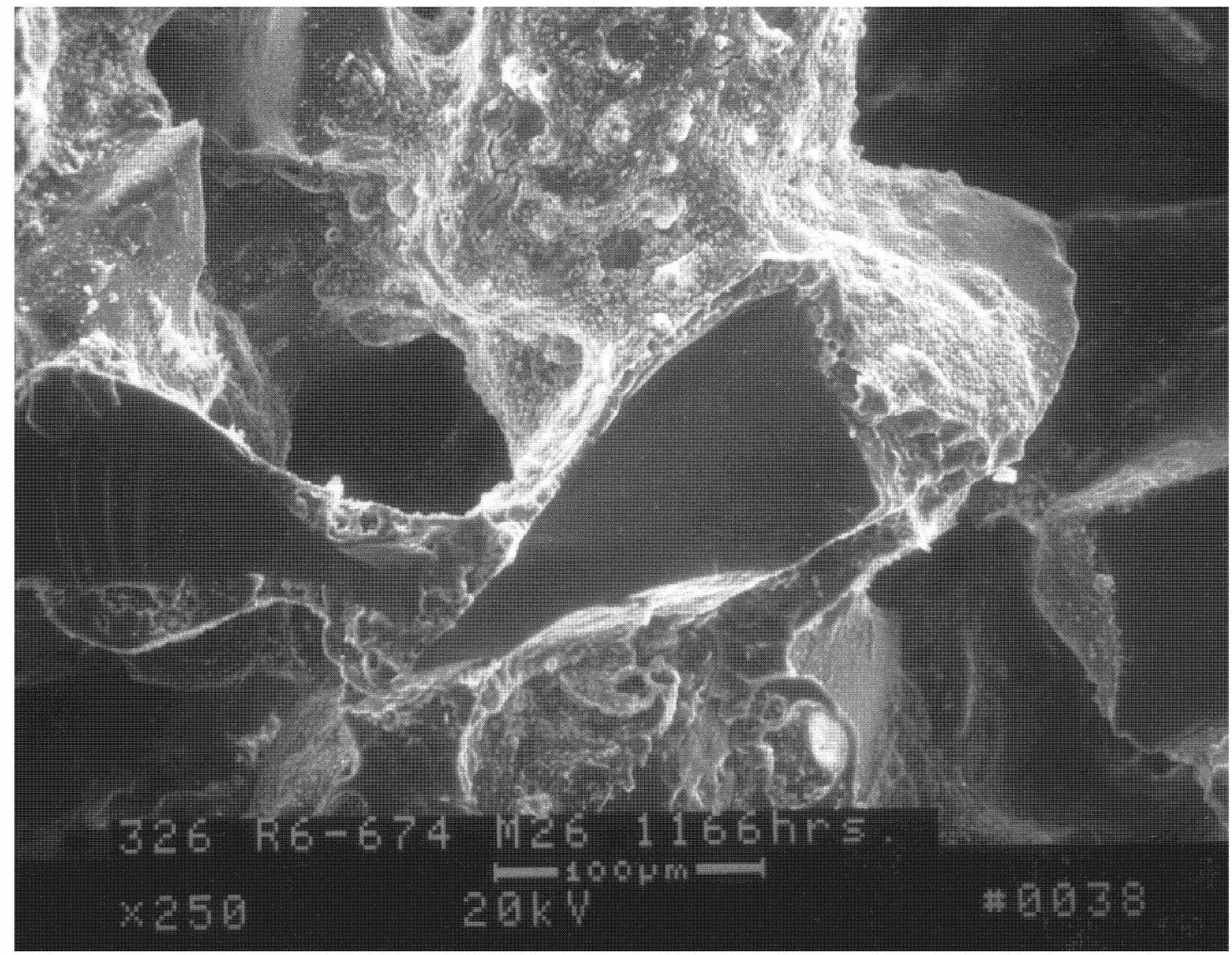

Figure 20 - Extensive crystallization that resulted along the coating that encapsulated the silicon carbide grains in the 1166 hour, PCFBC-exposed, Pall 326 filter matrix near the outer surface of the filter wall. 


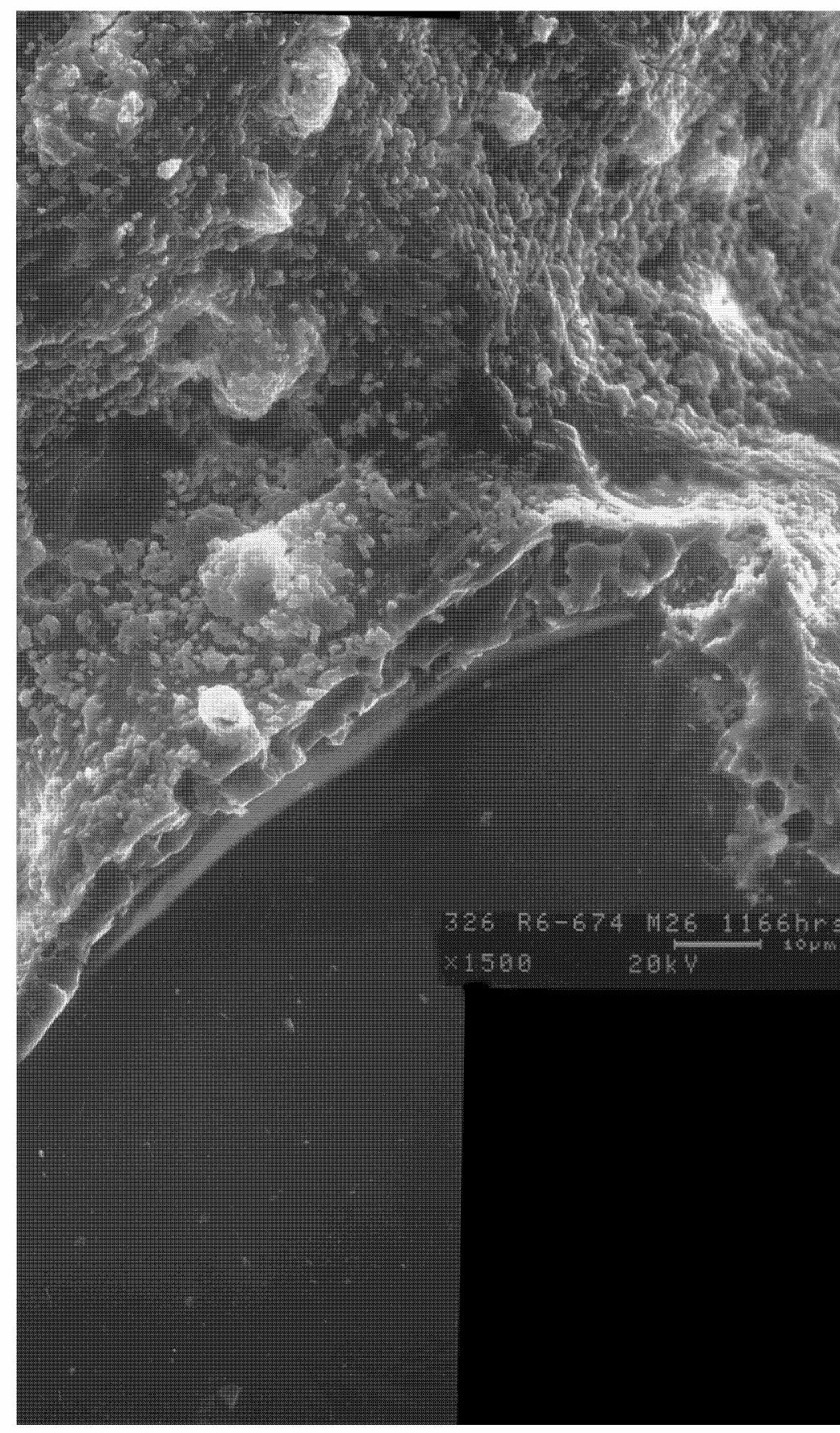

ter magnification micrograph montage illustrating the extensive crys Ited along the surface of the binder-enriched oxide coated silicon ca 166 hour, PCFBC-exposed, Pall 326 filter matrix. 


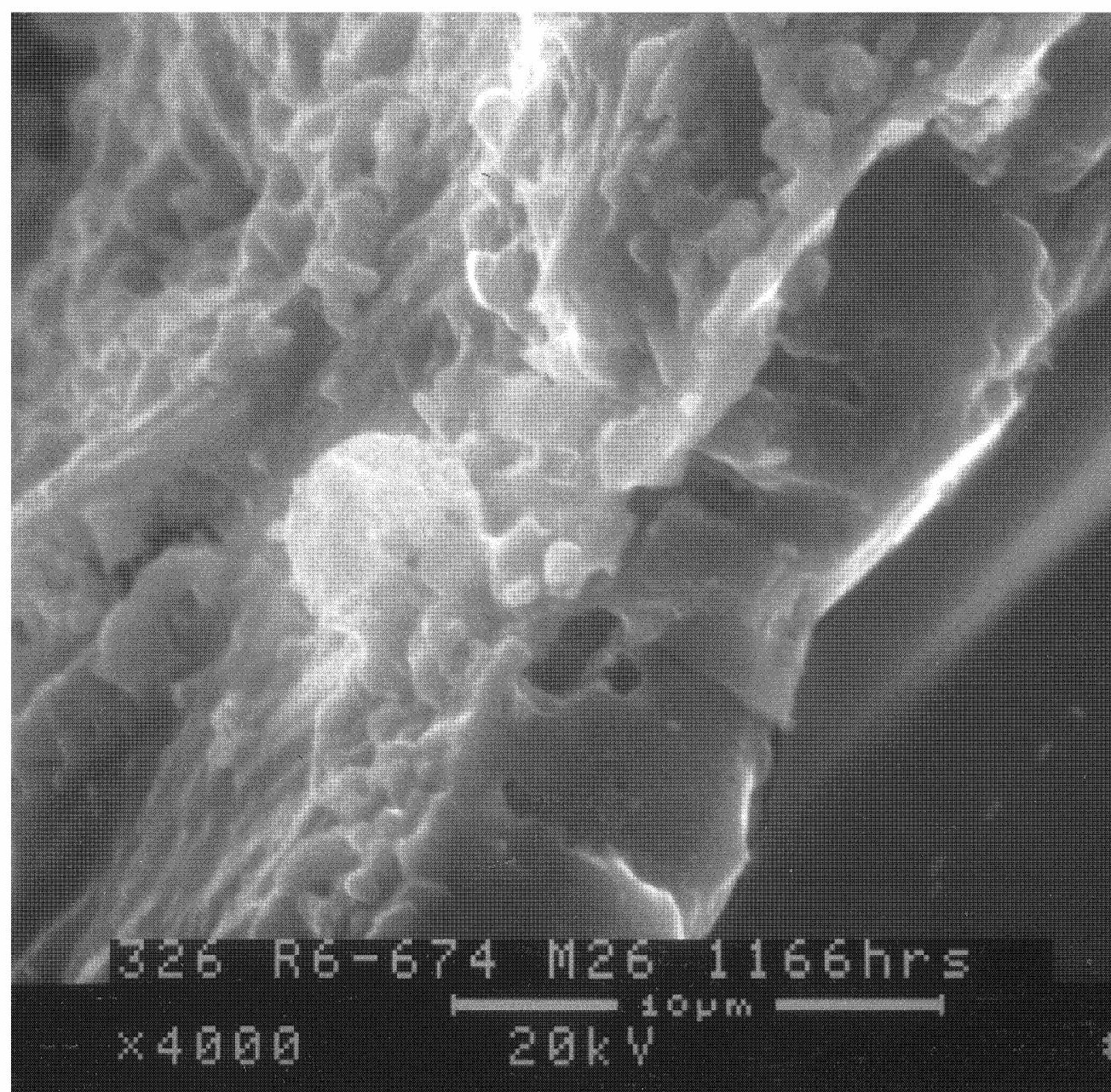

Figure 22 - Micrograph illustrating the thickness of the binder-enriched oxide coatin along the surface of the silicon carbide grains in the 1166 hour, PCFBC filter matrix. 


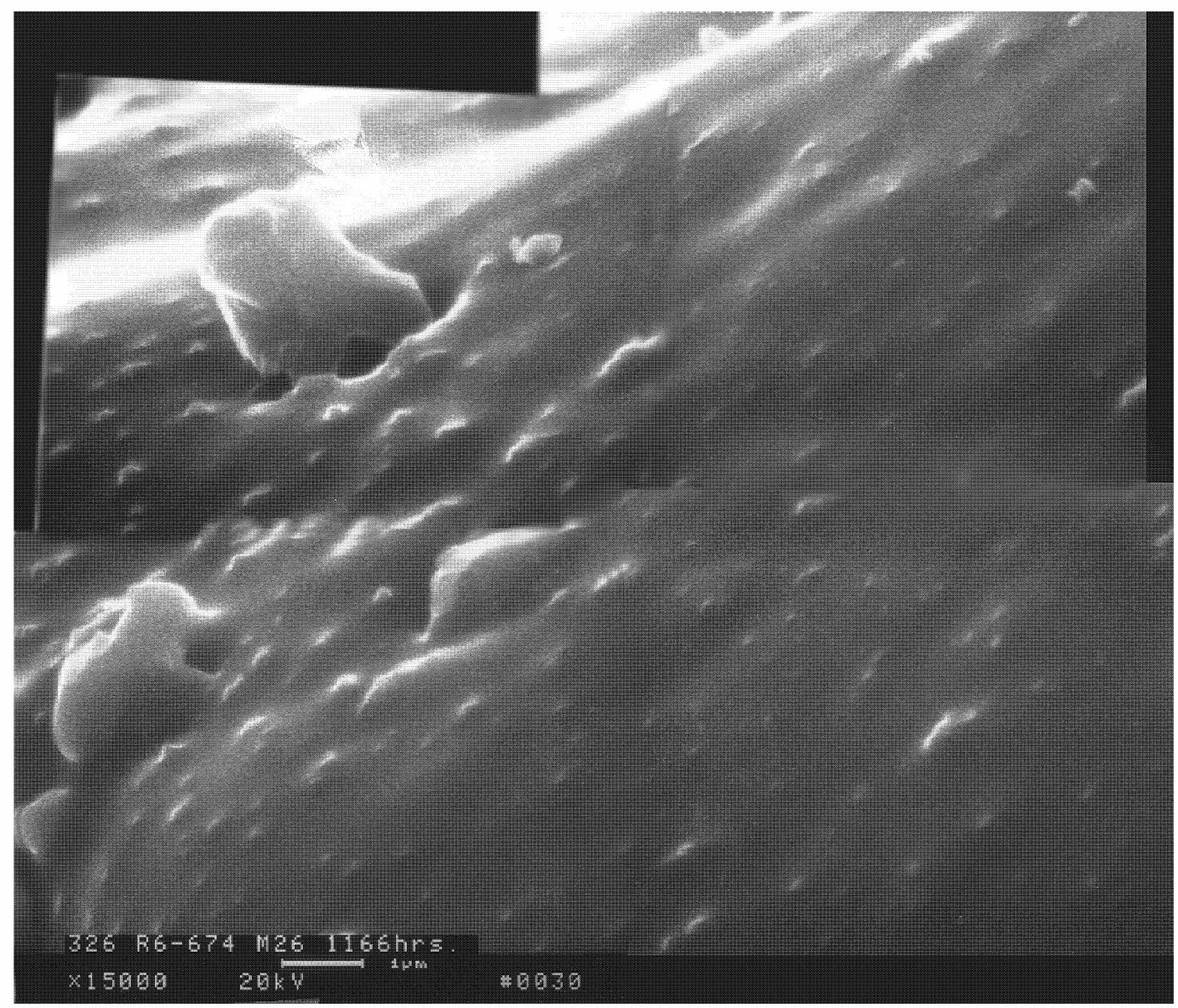

Figure 23 - Higher magnification micrograph montage illustrating the melt-like features of the binderenriched oxide coating that encapsulated the silicon carbide grains near the outer surface of the 1166 hour, PCFBC-exposed, Pall 326 filter element. 


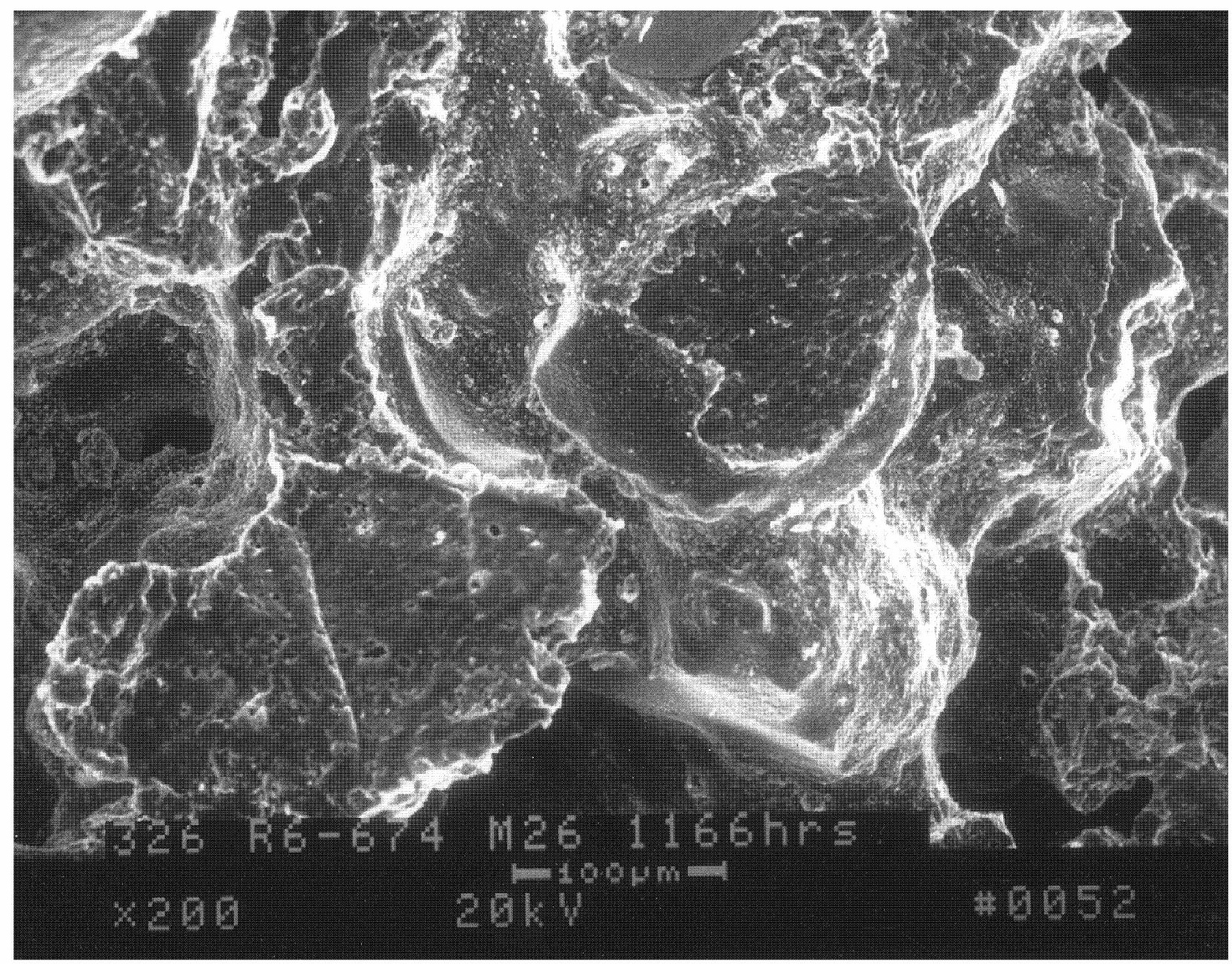

Figure 24 - Microstructure of the 1166 hour, PCFBC-exposed, Pall 326 filter matrix near the pulse cycled surface of the filter element. 
magnification in Figure 25. Below the encapsulating layer, the surface texture of the underlying silicon carbide grains was mottled resulting from what was considered to be surface oxidation of the grains during extended operation in the PCFBC environment (Figure 26).

\section{Coors P-100A-1 Alumina/Mullite Candle Filters}

In contrast to the clay bonded silicon carbide filter elements, the Coors P-100A-1 alumina/ mullite filter matrix consisted of mullite rods that were embedded within an amorphous phase that contained corundum $\left(\mathrm{Al}_{2} \mathrm{O}_{3}\right)$ and anorthite $\left(\mathrm{CaAl}_{2} \mathrm{Si}_{2} \mathrm{O}_{8}\right)$. The monolithic Coors P-100A-1 alumina/ mullite filter elements were manufactured without an external surface membrane.

Both newly manufactured Coors P-100A-1 alumina/mullite candles, and candles that had been operated in the $\mathrm{W}-\mathrm{APF}$ system at AEP were installed prior to initiating PCFBC testing in Test Segment 1 in the Foster Wheeler PCFBC test facility in Karhula, Finland. Post-test SEM/EDAX characterization of the 505 hour PCFBC-exposed, and 1650 hour PFBC/PCFBC-exposed Coors P-100A-1 alumina/mullite filters indicated that crystallization resulted along the pore cavity walls, and throughout the structural ligaments of the filter matrix (Figures 27 and 28).

At the conclusion of Test Segment 3, extensive crystallization was again observed along the pore cavity surfaces, and throughout the ligaments in the 1166 hour, PCFBC-exposed, and 2276 hour, PFBC/PCFBC-exposed, Coors P-100A-1 alumina/mullite filter matrices (Figure 29). Dendritic-like mullite rod formations protruded into the pore cavities (Figure 30), a fine grain phase frequently formed near the surface of the mullite rods (Figure 31), and a larger grain aluminosilicate phase formed along the surface of the pore cavities (Figure 32). In addition, a 3-4 $\mu \mathrm{m}$ nearly spherical aluminosilicate phase formed at the tip of the mullite rods primarily along the pulse cycled surface of the Coors P-100A-1 alumina/mullite filter matrix (Figure 33) .

\section{$\underline{\text { 3M CVI-SiC Composite Candle Filters }}$}

The 3M CVI-SiC composite filter elements consisted of three layers - an open mesh, outer confinement layer, a middle filtration mat layer, and an inner structural support triaxial braided layer. Within the confinement and filtration mat layers, an $\sim 1-2 \mu \mathrm{m}$ layer of silicon carbide was chemically vapor infiltrated along the surface of Nextel ${ }^{\mathrm{TM}} 312$ or alumina-based fibers, while an $\sim 100 \mu \mathrm{m}$ layer of silicon carbide was deposited along the Nextel ${ }^{\mathrm{TM}} 312$ triaxial braid in the support matrix.

When removed from the filter array after 387 hours of operation at $850^{\circ} \mathrm{C}$ in the PCFBC environment, a color change was readily evident along the outer confinement and possibly filtration mat layers of the 3M CVI-SiC composite candle filters (Figure 34). The original dark black color of the CVI$\mathrm{SiC}$ coating that encapsulated either the Nextel ${ }^{\mathrm{TM}} 312$ fibers in the outer confinement layer, or the alumina-based fibers in the filtration mat layer was not retained along the majority of the filter body. Instead after 387 hours of operation, the outer confinement layer appeared to be white (i.e., excluding the presence of ash fines), while the filtration mat layer was generally a light to medium grey. ${ }^{5}$ The initial consideration was that "bare" fibers were present in the outer confinement layer as a result of removal of the CVI-SiC encapsulating shell during exposure of the 3M CVI-SiC composite filter elements to the high temperature oxidizing environment. Generally the triaxial support braid which consisted of an

\footnotetext{
${ }^{5}$ A similar change in the color of the $3 \mathrm{M}$ CVI-SiC composite candle filters had been experienced at Westinghouse during qualification testing under simulated PFBC conditions.
} 


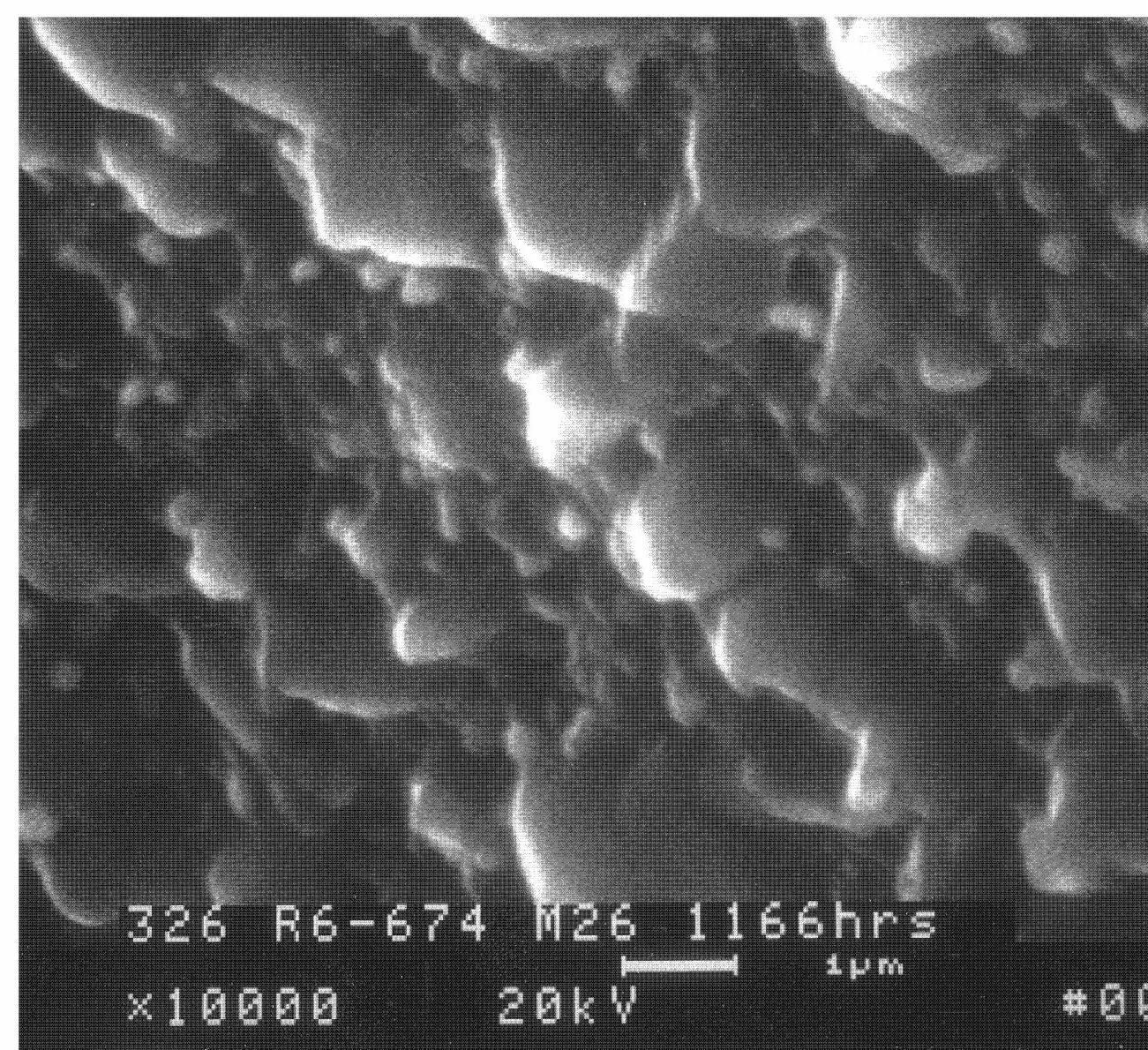

Figure 25 - Morphology of the silica-enriched oxide coating that encapsulated the carbide grains in the 1166 hour, PCFBC-exposed, Pall 326 filter eleme 


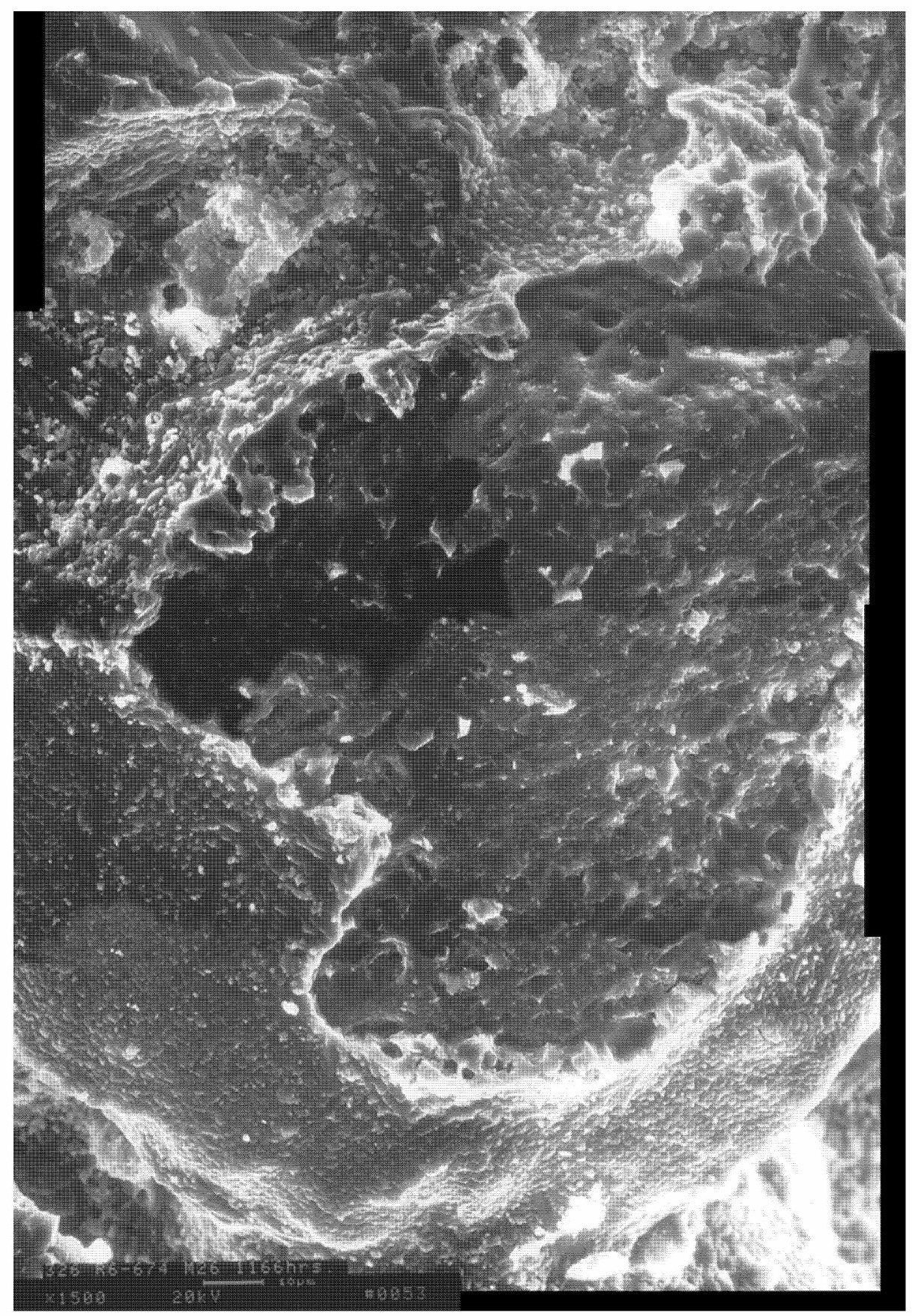

Figure 26 - High magnification micrograph montage illustrating extensive crystallization of the binder-enriched oxide coating that encapsulated the silicon carbide grains along the pulse cycled surface of the 1166 hour, PCFBC-exposed, Pall 326 filter element, and the mottled surface features of the underlying silicon carbide grains. 

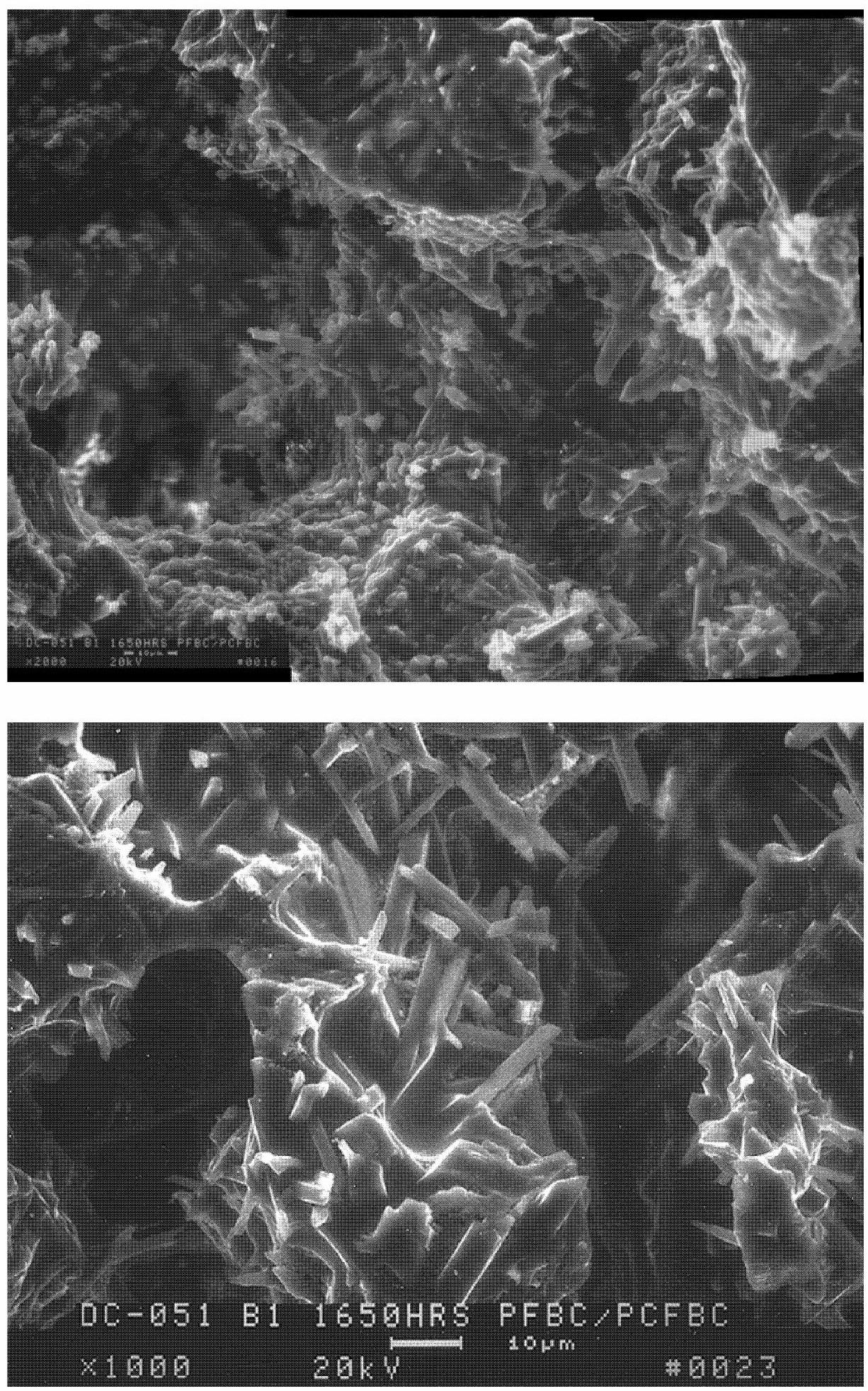

Figure 27 - Microstructure of the 505 hour, PCFBC-exposed, Coors P-100A-1 alumina/mullite filter matrix. 

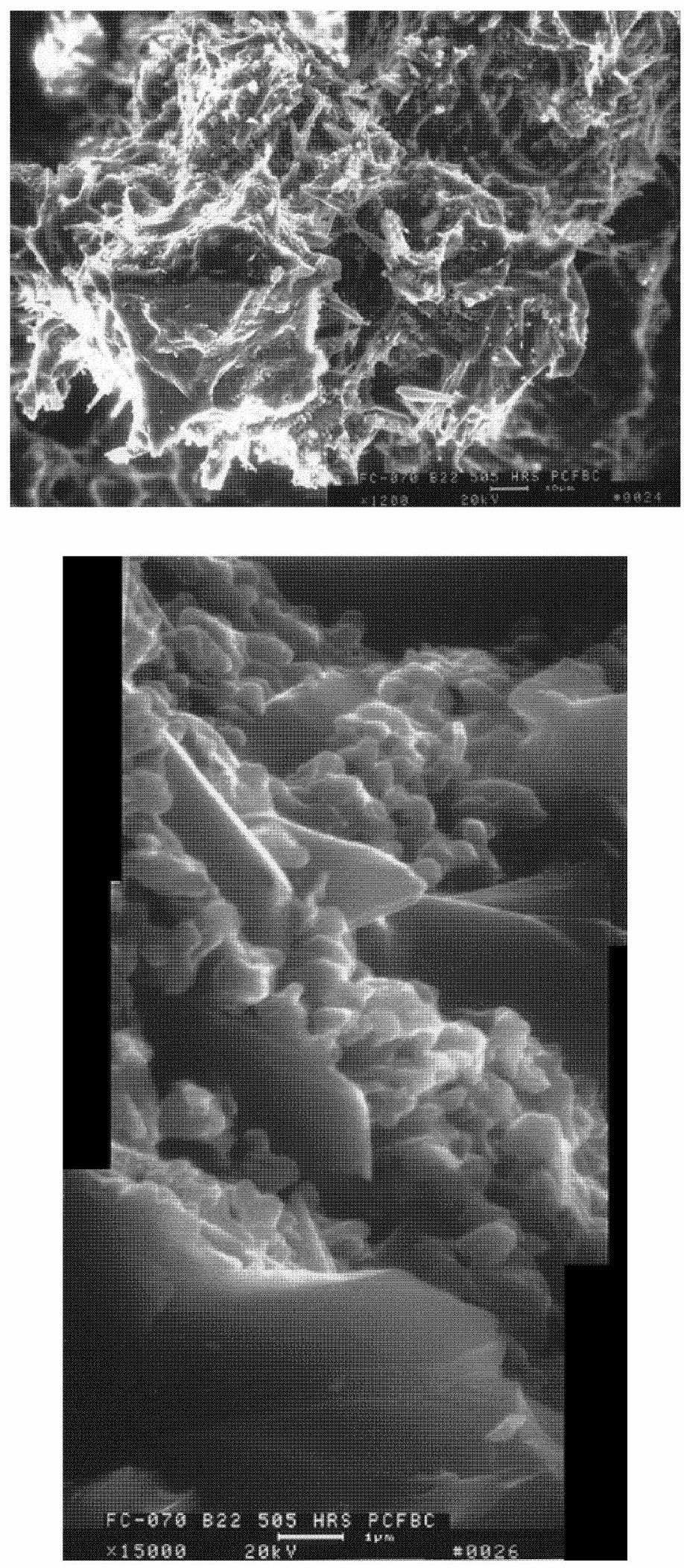

Figure 28 - Microstructure of the 1650 Hour, PFBC/PCFBC-exposed, Coors P-100A-1 alumina/mullite filter matrix. 


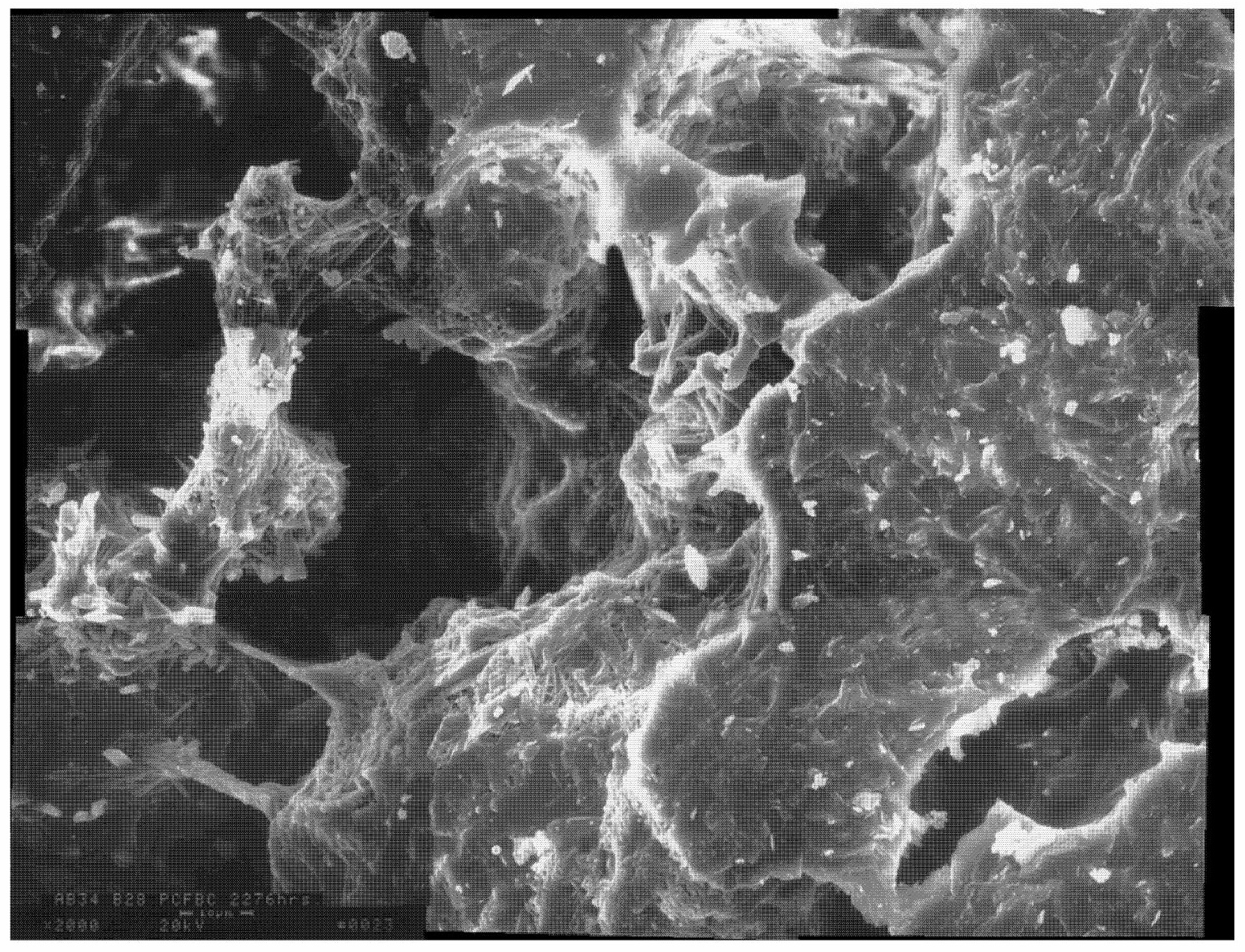

Figure 29 - High magnification micrograph montage illustrating the extensive crystallization that resulted throughout the ligaments and along the pore cavity surfaces of the 2276 hour, PFBC/PCFBC-exposed, Coors P-100A-1 alumina/mullite matrix. 


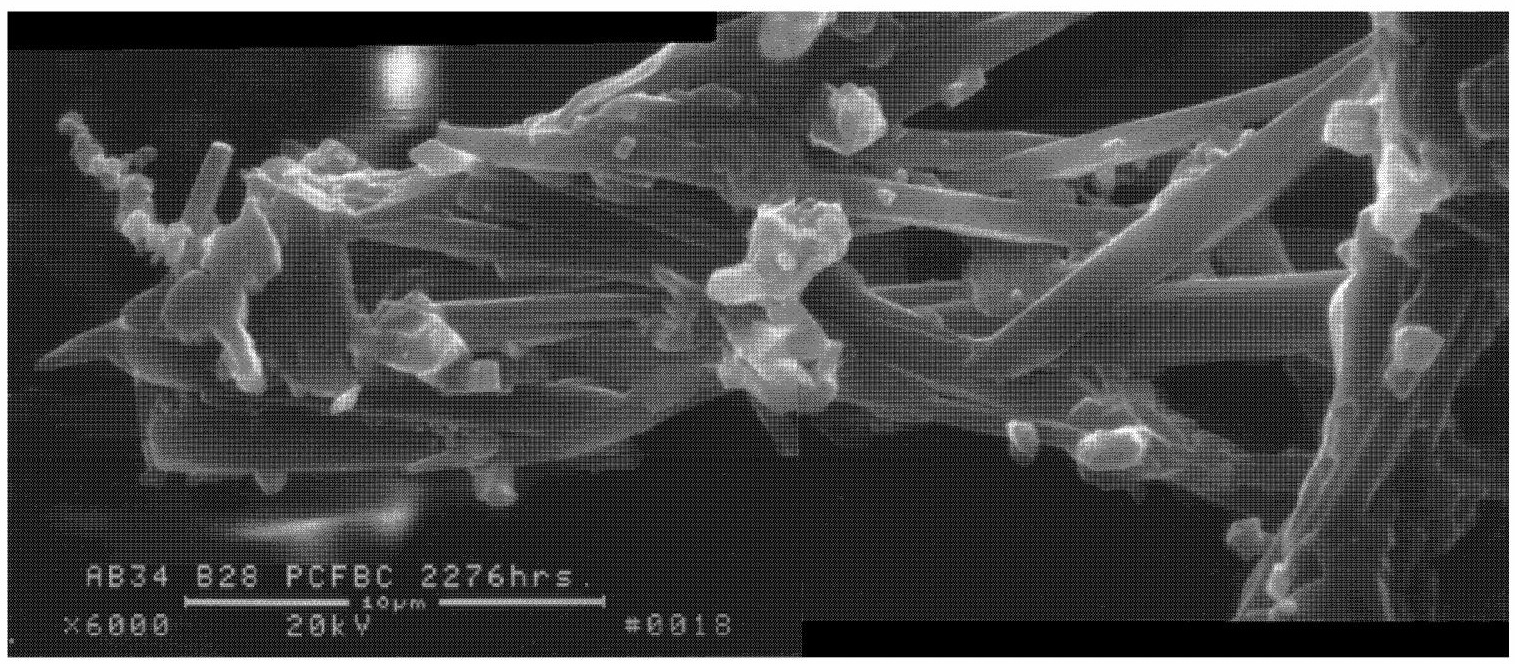

Figure 30 - Micrograph montage illustrating the formation of mullite-like rods that resulted along the surface of the pore cavity walls in the PFBC/PCFBC-exposed Coors P-100A-1 alumina/mullite filter matrix. 


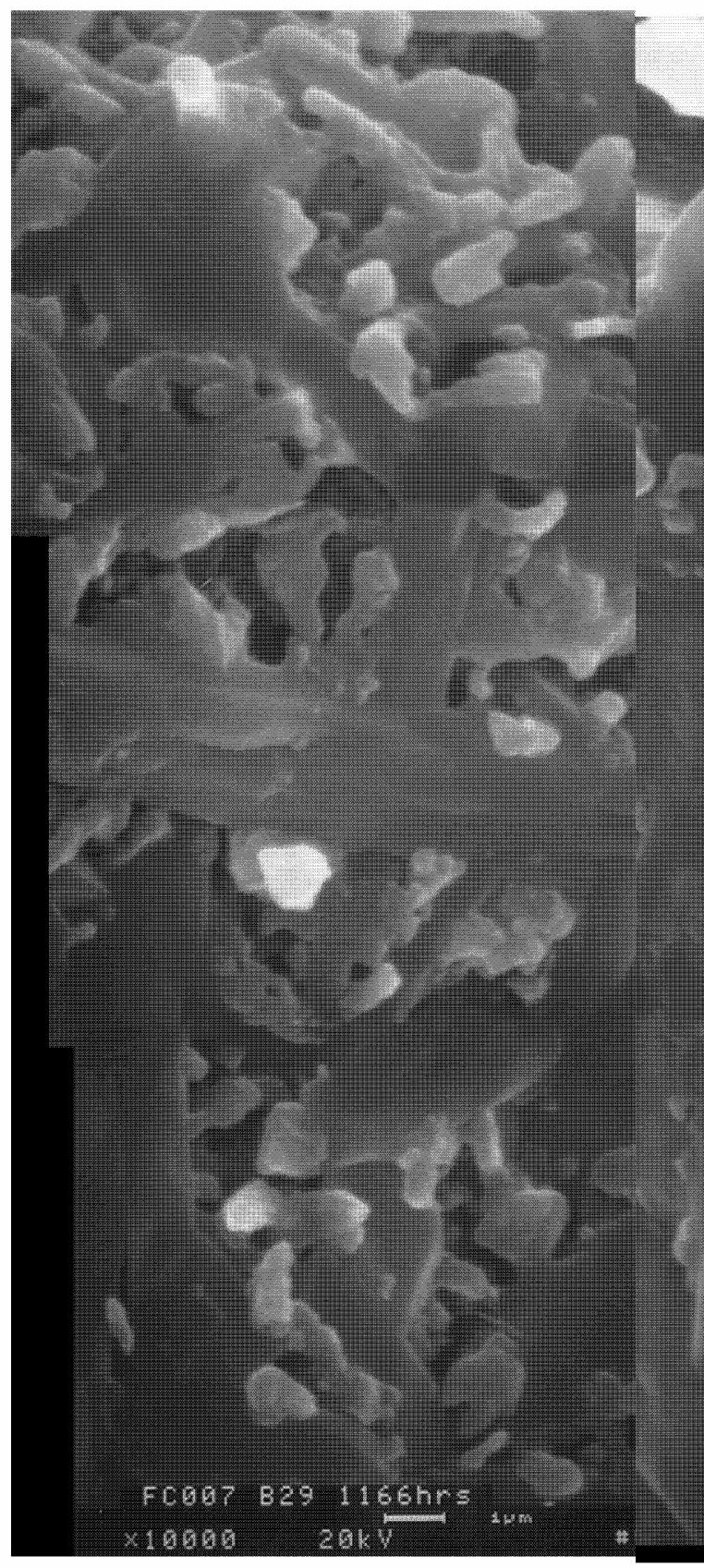

Figure 31 - High magnification micrograph ${ }_{\text {of a }}$ phase and mullite-like rods thafaces 1166 hour, PCFBC-exposed, Cer ma 


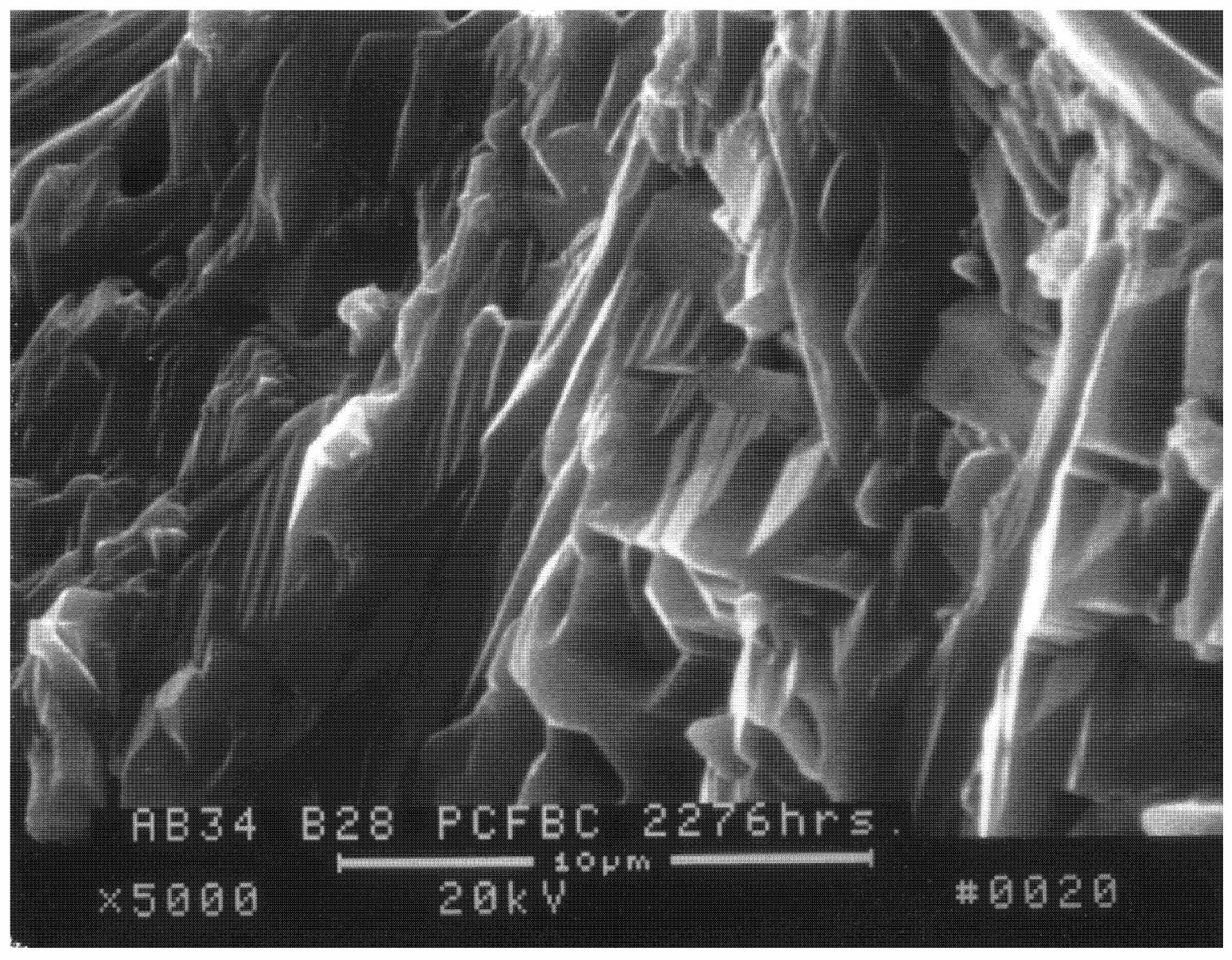

Figure 32 - Micrograph illustrating the morphology of the larger grain aluminosilicate phase that resulted along the pore cavity surfaces of the PFBC/PCFBC-exposed Coors P-100A-1 alumina/mullite filter matrix. 


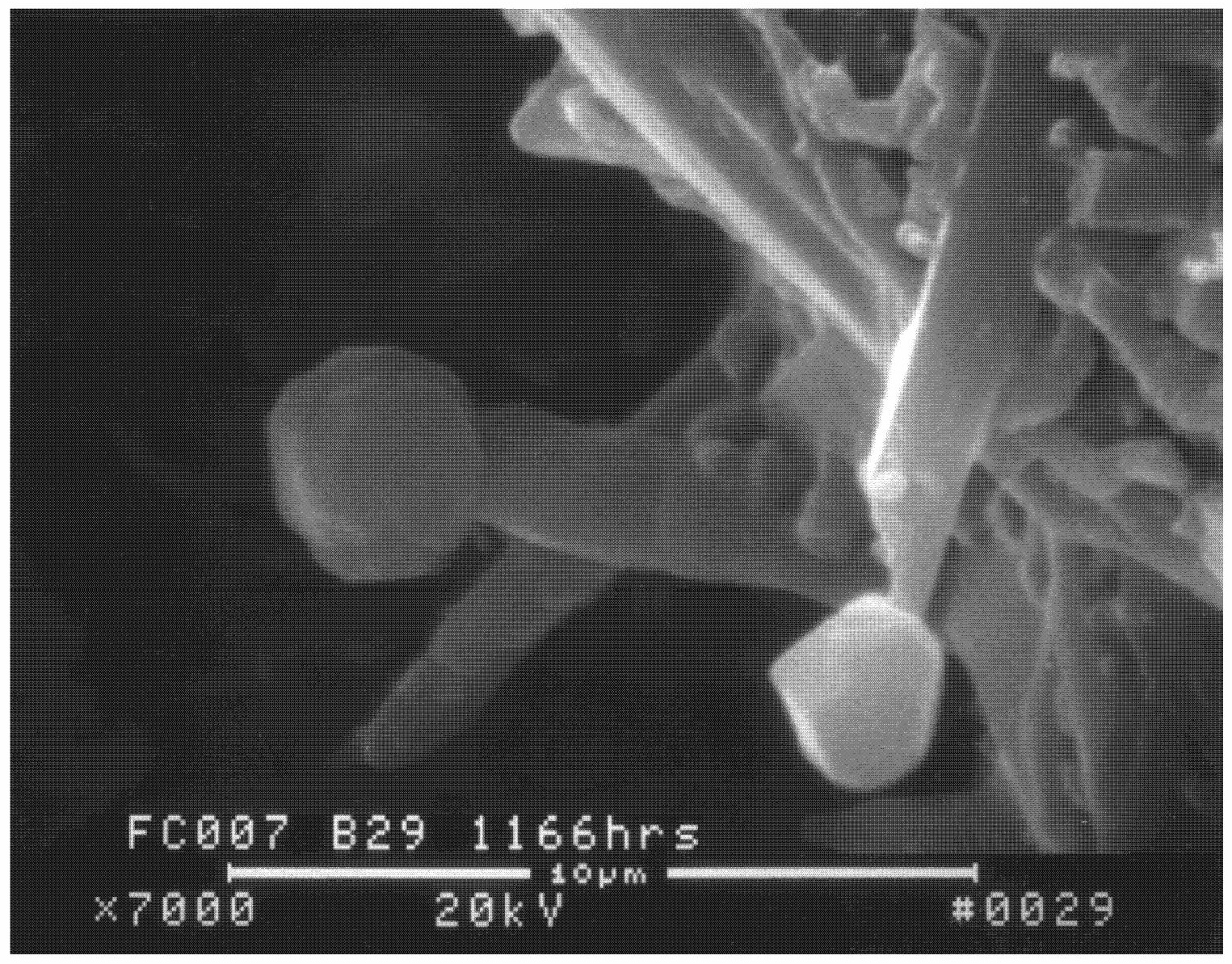

Figure 33 - Morphology of the crystalline features that typically formed at the tip of the mullite rods which extended into the pore cavities of the PCFBC-exposed, Coors P-100A-1 alumina/mullite filter matrix. 


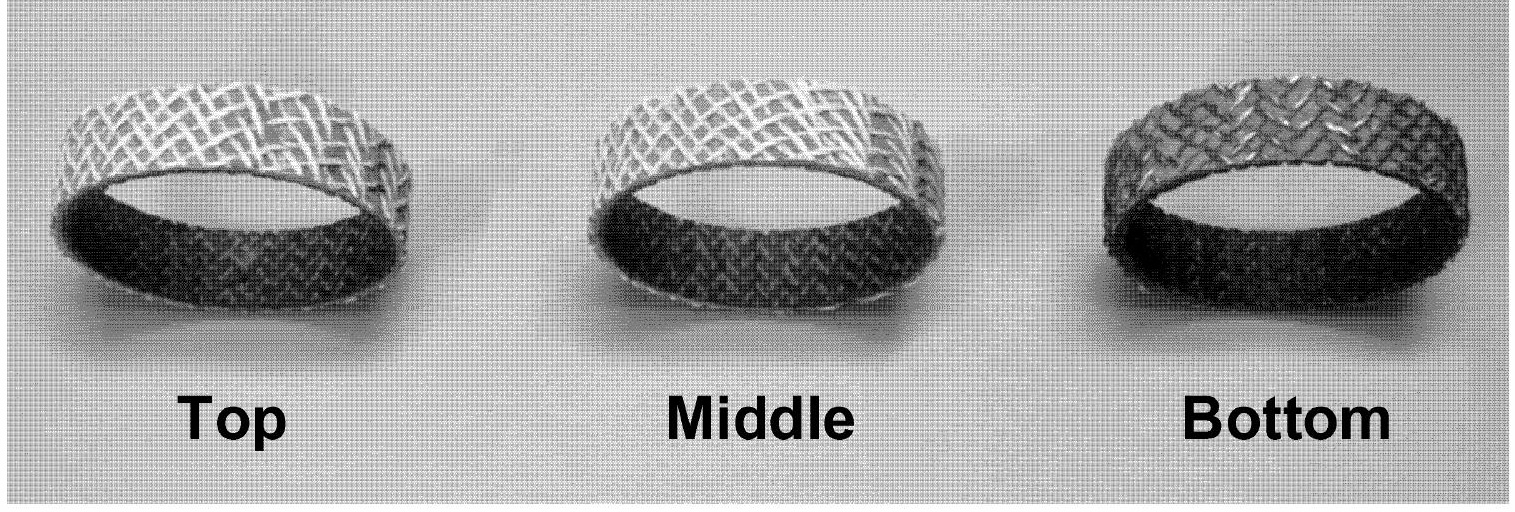

Figure 34 - Color gradient resulting along the length of the 3M CVI-SiC composite filters after operation in the PCFBC environment. 
$\sim 100 \mu \mathrm{m}$ CVI-SiC layer that encapsulated twisted Nextel ${ }^{\mathrm{TM}} 312$ filaments or fiber bundles, retained its as-manufactured dark black appearance.

SEM/EDAX characterization of the PCFBC-exposed 3M CVI-SiC composite filter matrix confirmed that removal of the SiC layer which initially encapsulated the Nextel ${ }^{\mathrm{TM}} 312$ fibers in the outer confinement layer had occurred. Characterization of the lapped filtration mat indicated that oxidation of the $2 \mu \mathrm{m}$ CVI-SiC shell had also occurred. As a result, an $\sim 1 \mu \mathrm{m}$ oxygen-enriched layer formed along the outer surface of the as-manufactured CVI-SiC coating. An oxygen-enriched region also formed along the inner surface of the CVI-SiC shell, bonding the shell to the filtration mat fibers (Figure 35). Bonding of the oxygen-enriched CVI-SiC shell to the fibers ultimately reduced the fracture toughness and possibly increased the strength of this layer.

Characterization of the triaxial support braid identified oxidation and pitting along the outer surface of the CVI-SiC shell that encapsulated the underlying Nextel ${ }^{\mathrm{TM}} 312$ filaments (Figure 36). Within the interior of the filament or fiber bundles, a thin layer of CVI-SiC generally coated individual fibers. Frequently gaps were evident between the thin CVI-SiC layers and the fibers, as well as areas which clearly showed bonding of the shell to the surface of the contained fibers.

\section{Gravimetric Analysis}

During post-test inspection of the 1166 hour, PCFBC-exposed, filter elements, the candles were visually inspected, and the overall lengths of the filter elements were measured. Cracks were not observed along the outer surface of the filter body (i.e., below the flange of the clay bonded silicon carbide candles). As shown in Table 8, an elongation of $9 \mathrm{~mm}$ was observed for the S350F/30 Schumacher Dia Schumalith FT20 candle, and between 6-8 mm of elongation was identified for the Pall 326 filter elements.

In order to discern whether oxidation of the silicon carbide grains was responsible for the resulting elongation or volume expansion of the clay bonded silicon carbide filter elements, three Schumacher Dia Schumalith FT20 and three Pall 326 filter samples were subjected to gravimetric analysis to determine the percent oxide that was present within each filter matrix. ${ }^{6}$ The materials that were selected for characterization included:

- As-manufactured Schumacher Dia Schumalith FT20 (S350F/108)

- 540 hour, PCFBC-exposed, Schumacher Dia Schumalith FT20 (S350F/8)

- 1166 hour, PCFBC-exposed, Schumacher Dia Schumalith FT20 (S350F/30)

- As-manufactured Pall 326 (R3-676)

- 540 hour, PCFBC-exposed, Pall 326 (R5-665)

- 1166 hour, PCFBC-exposed, Pall 326 (R6-674).

The results of the gravimetric analyses indicated that the as-manufactured Pall 326 filter matrix initially appeared to contain less free silica in comparison to the as-manufactured Schumacher Dia Schumalith FT20 filter matrix (Table 9). Operation in the PCFBC environment tended to enhance the concentration of silica within both clay bonded silicon carbide filter matrices.

\footnotetext{
${ }^{6}$ Initially the filter sample was crushed, weighed and dissolved in hydrogen fluoride (HF). After dissolution and drying, the sample was reweighed. The difference between the initial and final sample weight reflected the quantity of amorphous $\mathrm{SiO}_{2}$ (i.e., glass phase binder and/or oxidation product).
} 

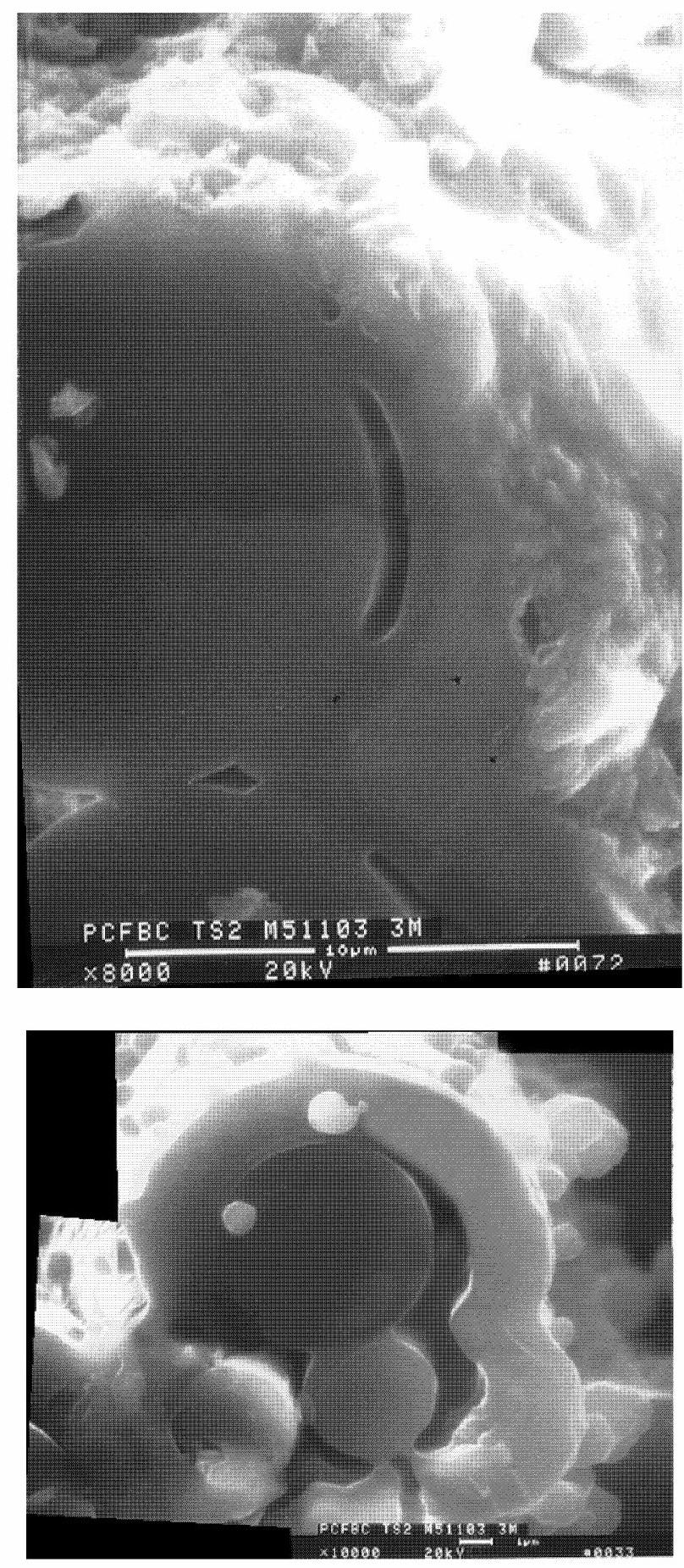

Figure 35 - Oxidation resulting along the outer and inner surfaces of the CVI-SiC encapsulating shell of the filtration mat fibers in the 387 hour, PCFBC-exposed, $3 \mathrm{M}$ composite filter matrix. 


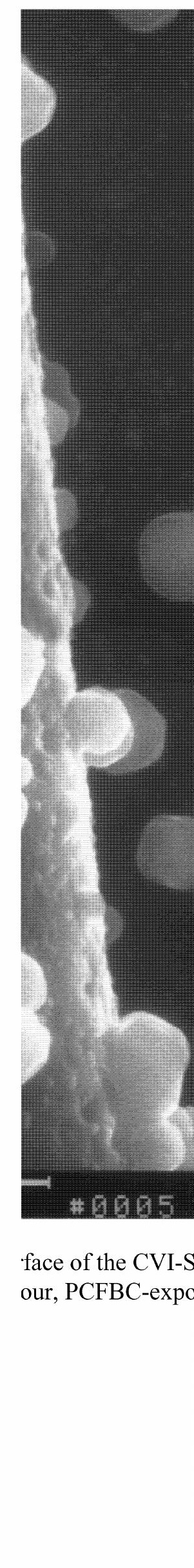




\begin{tabular}{|c|c|c|}
\hline \multicolumn{2}{|c|}{ TABLE 8 } \\
\multicolumn{2}{|c|}{ ELONGATION MEASUREMENTS } \\
\hline $\begin{array}{c}\text { Candle Identification Number } \\
\text { Initial/Final Length, mm }\end{array}$ & Comment \\
\hline $\begin{array}{c}\text { Schumacher Dia Schumalith } \\
\text { FT20 } \\
\text { (S350F/30) }\end{array}$ & $1514 / 1523$ & 9 mm elongation \\
\hline $\begin{array}{c}\text { Pall 326 } \\
\text { (R4-675) }\end{array}$ & $1503 / 1509$ & 6 mm elongation \\
\hline $\begin{array}{c}\text { Pall 326 } \\
\text { (R6-674) }\end{array}$ & $1502 / 1510$ & 8 mm elongation \\
\hline $\begin{array}{c}\text { (FC-035) } \\
\text { Coors P-100A-1 Alumina/Mullite }\end{array}$ & $1514 / 1515$ & $\begin{array}{c}\text { Difference attributed to } \\
\text { measurement techniques }\end{array}$ \\
\hline $\begin{array}{c}\text { Coors P-100A-1 Alumina/Mullite } \\
\text { (FC-007) }\end{array}$ & $\begin{array}{c}\text { Difference attributed to } \\
\text { measurement techniques }\end{array}$ \\
\hline $\begin{array}{c}\text { Coors P-100A-1 Alumina/Mullite } \\
\text { (EC-014; AB-34) }\end{array}$ & $\begin{array}{c}\text { Difference attributed to } \\
\text { measurement techniques }\end{array}$ \\
\hline
\end{tabular}


TABLE 9

SILICA CONCENTRATION IN THE AS-MANUFACTURED AND PCFBC-EXPOSED CLAY BONDED SILICON CARBIDE FILTER MATERIALS

Filter Designation

Operating Time, Hrs

Percent Silica

Schumacher Dia Schumalith FT20

$\mathrm{S}-350 / 108$

$\mathrm{S}-350 \mathrm{~F} / 8(\mathrm{~T} 12)$

$\mathrm{S}-350 \mathrm{~F} / 30(\mathrm{~T} 26)$

540

1166

11.72

17.23

15.51

Pall 326

\begin{tabular}{|c|c|c|}
\hline R3-676 & - & 6.86 \\
\hline R5-665 (M21) & 540 & 13.75 \\
\hline R6-674 (M26) & 1166 & 9.77 \\
\hline
\end{tabular}


For both Schumacher and Pall filter materials, a greater concentration of silica appeared to be present after 540 hours of PCFBC operation in comparison to the concentration of silica present after 1166 hours of operation. The 1166 hour, PCFBC-exposed, Schumacher and Pall filter matrices may have oxidized to a greater extent than the 540 hour, PCFBC-exposed matrices, but much of the newly formed $\mathrm{SiO}_{2}$ was expected to have crystallized to form cristobalite. Cristobalite is more resistant to HF attack and thus, it was not detected by the analysis technique. Continued exposure of both clay bonded silicon carbide candle filters in the high temperature PCFBC environment is needed to determine the rate and extent of oxidation during extended field operation.

\section{High Temperature Oxidation vs Creep}

Based on the gravimetric analyses which identified the increased silica concentration in the field-exposed filter materials, and the bench-scale, high temperature, flexural creep tests which identified negligible creep strain in the as-manufactured and field-exposed filter materials, oxidation of the silicon carbide matrix was considered to be the primary mechanism that was responsible for the 6-9 $\mathrm{mm}$ of elongation that was observed for the $1.5 \mathrm{~m}$ Schumacher Dia Schumalith FT20 and Pall 326 filter elements after 1166 hours of PCFBC operation. During oxidation of the silicon carbide grains, $\mathrm{SiO}_{2}$ formed resulting in a volume expansion of the matrix. Based on an assumed average $\mathrm{SiC}$ grain size of $300 \mu \mathrm{m}$ within the $1.5 \mathrm{~m}$ Schumacher or Pall filter elements, the formation of an addition $1 \mu \mathrm{m}$ of $\mathrm{SiO}_{2}$ is projected to have resulted around the individual $\mathrm{SiC}$ grains within $\sim 1000$ hours of PCFBC operation in order to account for the 6-9 mm of elongation identified at the conclusion of Test Segment 3. Assuming that oxidation continues at this rate for 25,000 hours of PCFBC operation (i.e., 3 year candle life), $\sim 150 \mathrm{~mm}$ of elongation ( $\sim 6$ inches) would be encountered over the length of the $1.5 \mathrm{~m}$ filter body. Contact with the ash shed, added weight due to the formation of the oxide, and possible softening of the $\mathrm{SiO}_{2}$ phase at the grain-cristobalite interface may impart failure and/or high temperature creep of the elements during extended plant service operation. Continued operation of the previously PCFBC-exposed Schumacher and Pall filter elements is therefore recommended to determine the rate at which oxidation/ elongation/creep occurs within the clay bonded silicon carbide materials as a function of extended plant operating time.

During PCFBC operation, consideration should also be given to competing volatilization mechanisms that release $\mathrm{Si}(\mathrm{OH})_{4}$ from the silicon carbide filter matrix in the presence of steam. In contrast to oxidation, volatilization would be expected to reduce the overall volume of the silicon carbide grains.

\section{Additional Comments}

With the exception of the ash bridging event that occurred during Test Segment 2, catastrophic failure of the advanced monolithic and fiber reinforced filter elements did not occur as a response of the porous ceramic materials to normal PCFBC process operating conditions. Post-test inspection of the candle filters at the conclusion of Test Segment $3 \mathrm{did}$, however, indicate the somewhat fragile nature of the $3 \mathrm{M}$ filter elements. As shown in Figure 37, the flange of one of the five 3M CVI-SiC composite filter had cracked, presumably as a result of ash becoming wedged in between the holder and outer surface of the flange wall. Neither penetration of fines into the clean gas stream nor catastrophic failure of the element occurred. Similarly $\sim 5-10 \mathrm{~mm}$ sections of the outer confinement layer were seen to have been removed along several of the $3 \mathrm{M}$ filter elements at the conclusion of Test Segment 3 (Figure 38). This 


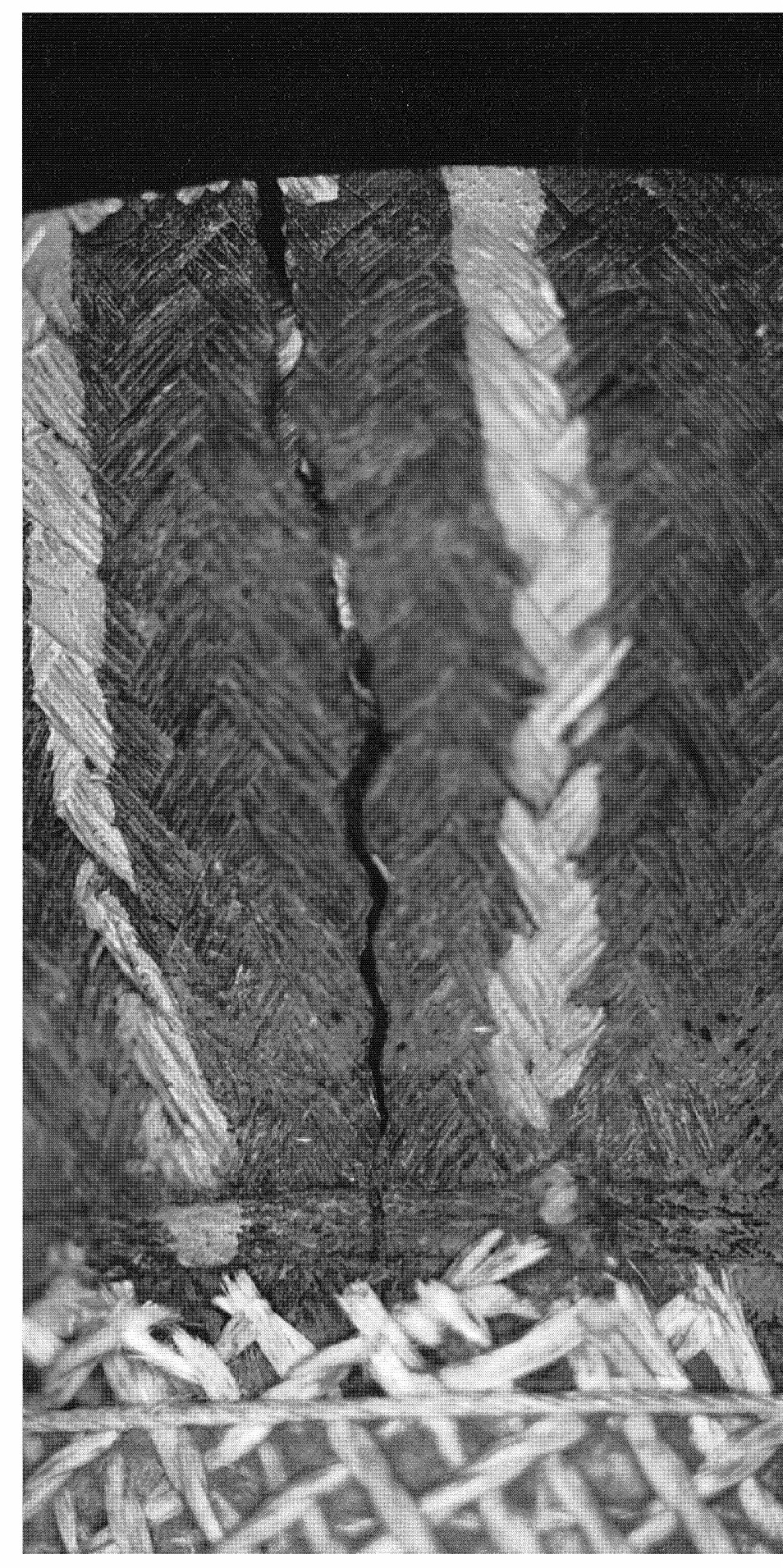

mations along the flange of the $3 \mathrm{M} \mathrm{CVI-SiC}$ composite cand of PCFBC operation in Test Segment 3. 


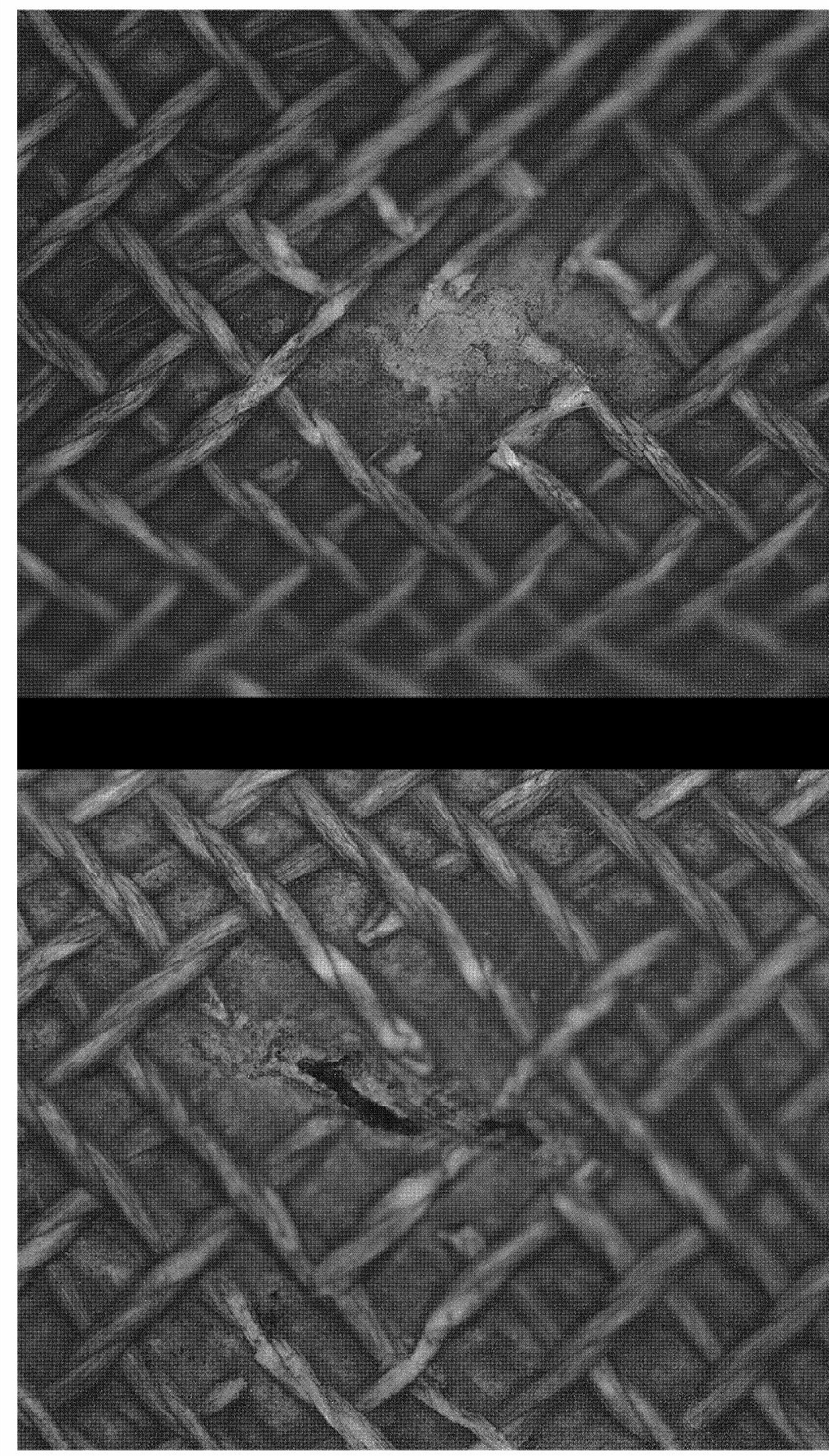

:moval of the outer confinement and filtration mat layers in the $626 \mathrm{~h}$ CFBC-exposed, 3M CVI-SiC composite filter element (Test Segme 
most likely occurred during in-situ cleaning of the array during interim inspection and maintenance intervals.

As shown in Figure 39, crack formations were evident near and around the densified plug which formed the closed end cap in three of the forty-five Pall 326 filter elements that were installed and operated in the W-APF during Test Segment 3. Although fines penetration was not observed through the crack formations after 1166 hours of PCFBC operation, continued use of these elements was not recommended.

\section{Ash Characterization}

\section{Scanning Electron Microscopy/Energy Dispersive X-Ray Analysis}

During operation in Test Segments 1 and 2 at the Foster Wheeler PCFBC test facility in Karhula, Finland, Illinois 6 coal and Linwood limestone were used as feed materials. Samples of the ash cake deposits which formed at various locations in the W-APF at the conclusion of Test Segment 2 were removed and subjected to SEM/EDAX analyses. Typically two types of particles were identified to be present within the ash cake layer that deposited along the outer surface of the candle filters (Figures 40 and 41). These included:

- Submicron and micron particulates that were enriched with aluminum and silicon. These particles were considered to be entrained fly ash fines that were released during the combustion of coal. Melt-like features were evident along the surface of the ash fines.

- Larger sulfated or partially sulfated calcium-based sorbent fines.

The aluminum and silicon-enriched coal ash fines were generally seen to adhere to the larger sulfated or partially sulfated sorbent fines. Extensive crystalline features were evident along the outer surface of the sorbent particles. Agglomeration of crystalline formations and/or melt-like features were detected, particularly along the surface of coal ash fines. In addition, spherical, $\sim 10 \mu \mathrm{m}$ particles enriched with silicon and calcium were also present within the deposited ash cake layer.

Dense packing of fines resulted within the ash cake layer that formed along the outer surface of the candle filters. Based on the analyses conducted, the cross-sectioned ash cake deposit did not show evidence of fracturing of bonds or melt-like phases that may have originally been present between adjacent particles. This implied close packing of fines, with limited point contact between particles prior to fresh fracturing of the deposited ash cake layer.

Ash deposits that collected along the metal filter holders were also characterized. SEM/EDAX analysis indicated that porosity existed within the interconnective network of ash and sorbent particles that deposited around the metal filter holders. Within the deposit, a melt-like phase formed, sintering adjacent particles together. The sintered bonds frequently formed point contact necks and channels between particles within the PCFBC deposit. The bonds were identified by EDAX to be silicon and/or silicon-aluminum-enriched.

Sorbent particles were also present within the ash cake deposit that formed around the metal filter holders. Based on EDAX analyses, the limestone sorbent was considered to be completely or 

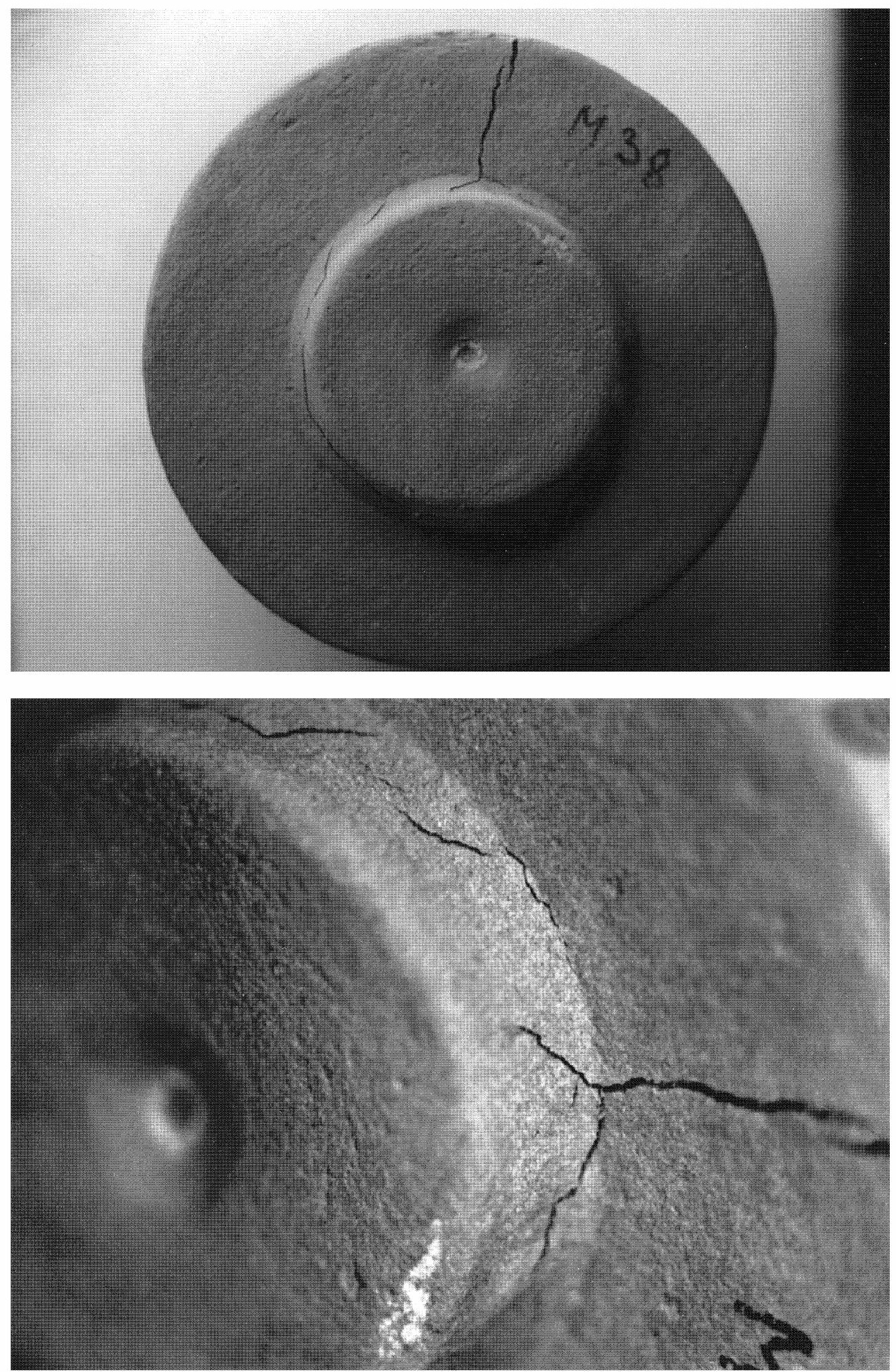

Figure 39 - Crack formations around the densified plug insert in the 1166 hour, PCFBC exposed, Pall 326 filter elements (Test Segment 3). 

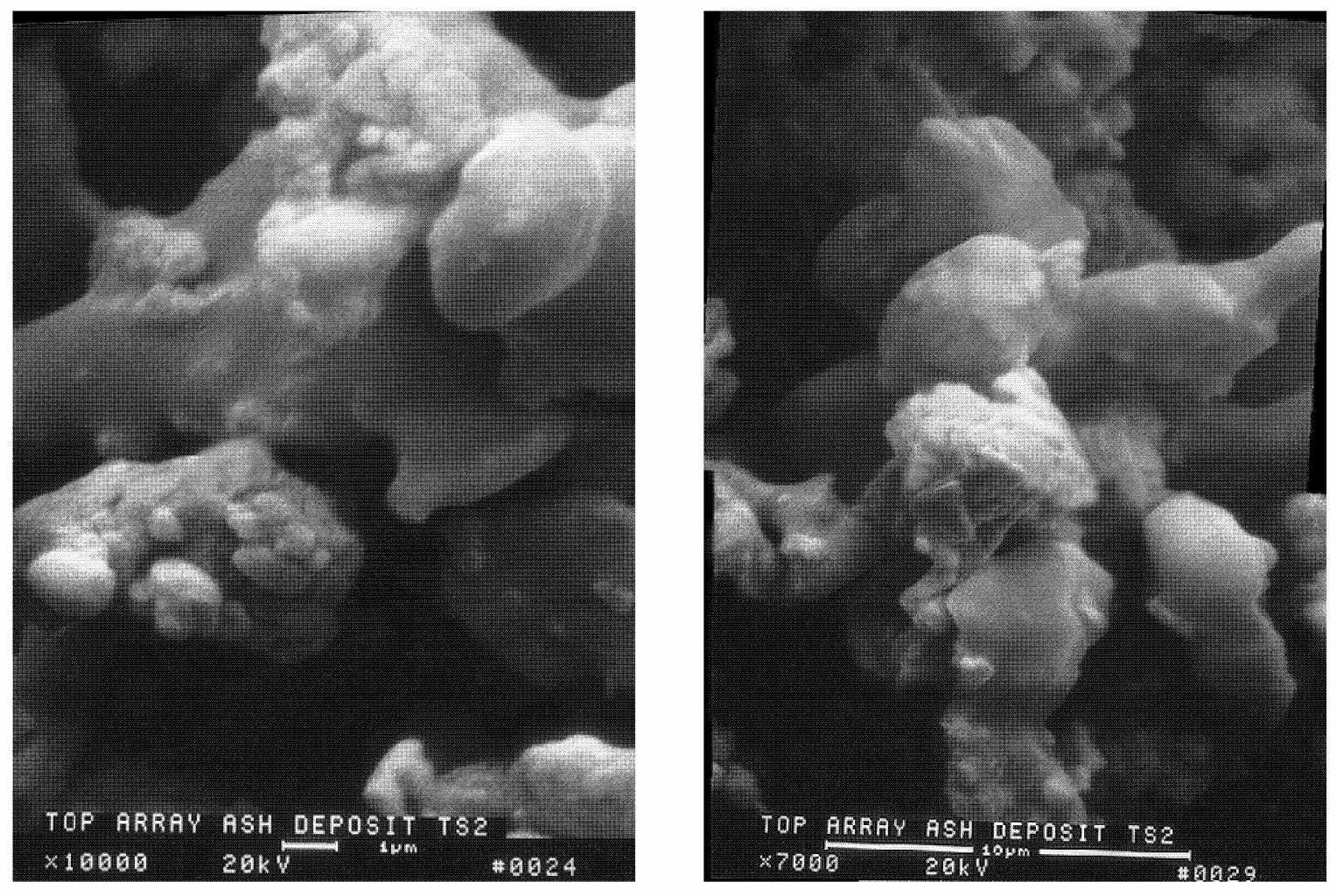

Figure 40 - Morphology of the PCFBC dust cake deposit that formed along the surface of the candle filters at the conclusion of Test Segment 2 in April 1996. 


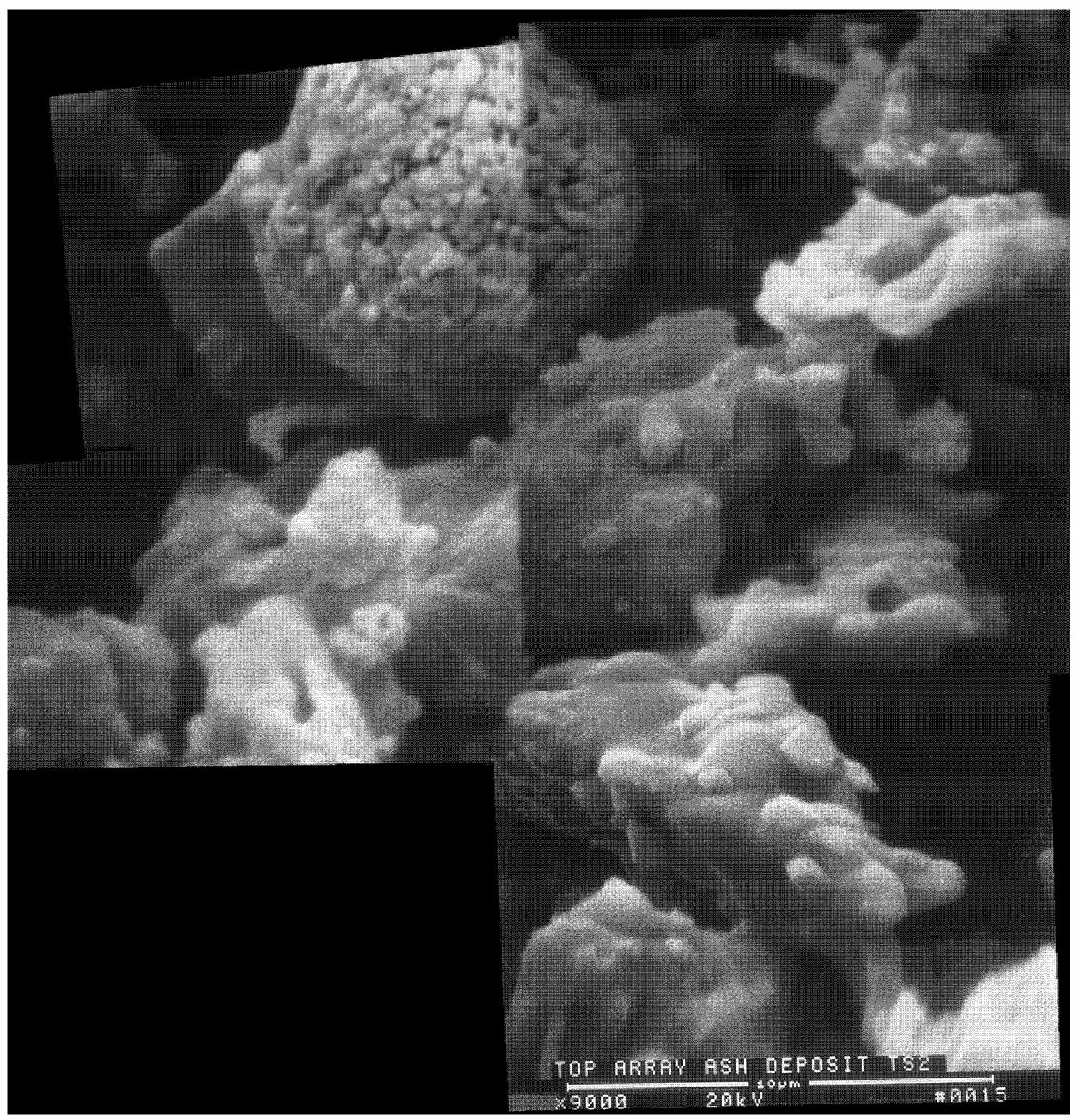

Figure 41 - Micrograph indicating extensive interconnectivity within the highly porous PCFBC dust cake deposit that formed along the surface of the candle filters at the conclusion of Test Segment 2 in April 1996. 
nearly completely sulfated. As in the filter cake deposit, the metal holder deposit contained discrete sorbent fines which were larger than the retained ash fines or agglomerates.

Similar analyses were conducted on ash removed from the filter hopper. A greater quantity of the larger calcium-containing sorbent and possibly the iron-enriched particles was detected in the ash hopper deposit in comparison to the quantity of these particles found within either the filter ash cake layer or metal holder deposits. When viewed at high magnification, the filter hopper ash was seen to also contain extensive porosity. Porosity resulted from the interconnective network of fines that were held together through a silicon and/or aluminum-silicon-enriched melt-like point contact neck or channel phase.

\section{X-Ray Diffraction Analysis}

X-ray diffraction (XRD) analyses were conducted on select PCFBC dust cake deposits that formed at the conclusion of Test Segment 2. As shown in Table 10, the PCFBC ash which was generated during the combustion of Illinois coal and Linwood limestone consisted primarily of anhydrite and quartz, with secondary contributions of hematite, aluminosilicate phases, and an amorphous phase.

In order to determine whether the bulk composition of the filter cake changed when Iowa Industrial limestone and resized Linwood limestone were used in Test Segment 3, additional XRD analyses were conducted for the following six samples: ${ }^{7}$

- $\quad \mathrm{T} 26$ - Residual ash cake deposit formed along S-350F/30 (1166 hrs) ${ }^{8}$

- M26 - Residual ash cake deposit formed along R6-674 (1166 hrs) ${ }^{8}$

- B31 - Residual ash cake deposit formed along 3M-51153 (627 hrs $)^{8}$

- Top plenum bridge between inner ring candles 36-38 and support column 13.10.1996

- Middle plenum 25.10.1996 bridging between inner ring and support column (Area 27-28)

- Bottom plenum 28.19.1996 bridging between candle area 18-19.

As shown in Table 11, both the residual dust cake layer that remained along the surface of the candle filters, and ash bridged materials consisted principally of calcium sulfate with quartz and hematite as nearly equivalent secondary phases. Additional feldspar and pyroxene phases were present within the dust cake layer that formed along the surface of the filter elements. Although major, these phases were present at concentrations that were slightly lower than the secondary quartz and hematite phases. In contrast, however, the concentration of the feldspar and pyroxene phases were either equivalent to or greater than the concentration of quartz and hematite within the various ash bridged materials. Based on the XRD analyses provided in Table 11, the concentration of calcium sulfate within the dust cake layer appeared to decrease as a function of array location (i.e., top $>$ middle $>$ bottom).

\footnotetext{
${ }^{7}$ The residual ash cake layer that remained along the surface of the various filter elements was easily removed, and was very friable. The size of the ash sample that was submitted for XRD analysis was $\sim 5-10 \mathrm{~mm}$ long/wide $\mathrm{x} 1 \mathrm{~mm}$ thick. The bridged materials were easily broken, and 25-35 mm long/wide x $10 \mathrm{~mm}$ thick samples were submitted for XRD analyses.

${ }^{8}$ Each filter element had been initially cleaned prior to installation/operation within the W-APF filter array during Test Segment 3 in 1996. Both sorbent materials were expected to be present within the conditioned ash cake layer that remained along the outer surface of the filter elements at the conclusion of Test Segment 3.
} 
TABLE 10

XRD ANALYSIS OF THE PCFBC ASH DEPOSITS, wt\%

- Test Segment 2 -

\begin{tabular}{|c|c|c|c|c|c|c|}
\hline $\begin{array}{c}\text { Sample } \\
\text { Identification }\end{array}$ & $\begin{array}{c}\text { Anhydrite } \\
\left(\mathbf{C a S O}_{4}\right)\end{array}$ & $\begin{array}{c}\text { Hematite } \\
\left(\mathbf{F e}_{2} \mathbf{O}_{3}\right)\end{array}$ & $\begin{array}{c}\mathbf{Q u a r t z} \\
\left(\boldsymbol{\alpha}-\mathbf{S i O}_{\mathbf{2}}\right)\end{array}$ & $\begin{array}{c}\text { Alumino- } \\
\text { silicate }^{(\mathbf{b})}\end{array}$ & $\begin{array}{c}\text { Amorphous } \\
\mathbf{P h a s e ( s )}\end{array}$ & Unknowns \\
\hline $\begin{array}{c}\text { Candle T25 } \\
\text { Concave Surface Of } \\
\text { Ash Deposit }\end{array}$ & 46 & 11 & 40 & Trace & Small & 3 \\
\hline $\begin{array}{c}\text { Candle T25 } \\
\text { Mid Section Of Ash } \\
\text { Deposit }\end{array}$ & 51 & 9 & 34 & 4 & Small & 2 \\
\hline $\begin{array}{c}\text { Candle T25 } \\
\text { Convex Surface Of } \\
\text { Ash Deposit }\end{array}$ & 51 & 9 & 33 & 4 & Small & 3 \\
\hline $\begin{array}{c}\text { Ash Hopper } \\
\text { Deposit } \\
\text { Outer Surface }\end{array}$ & 60 & 9 & 21 & 7 & Small & 3 \\
\hline $\begin{array}{c}\text { Ash Hopper } \\
\text { Deposit } \\
\text { Mid Section }\end{array}$ & 53 & 9 & 27 & 4 & Small & 3 \\
\hline $\begin{array}{c}\text { Top Array Holder } \\
\text { Deposit } \\
\text { Outer Surface }\end{array}$ & 57 & 9 & 28 & 3 & Small & 0 \\
\hline $\begin{array}{c}\text { Top Array Holder } \\
\text { Deposit } \\
\text { Mid Section }\end{array}$ & 60 & 9 & 8 & Small & 4 \\
\hline
\end{tabular}

(a) Illinois coal and Linwood limestone deposit.

(b) Possible phases include: $\mathrm{CaAl}_{2} \mathrm{Si}_{2} \mathrm{O}_{8}$ (Anorthite); $\mathrm{CaAl}_{2}\left(\mathrm{Si}_{2} \mathrm{OAl}_{2}\right) \mathrm{O}_{10}(\mathrm{OH})_{2}$ (Margarite); $\mathrm{Al}_{2} \mathrm{SiO}_{5}$ (Kyanite). 


\begin{tabular}{|c|c|c|c|c|c|c|}
\hline \multicolumn{7}{|c|}{ TABLE 11} \\
\hline \multirow{2}{*}{$\begin{array}{l}\text { Identified } \\
\text { Phase }^{(a)}\end{array}$} & \multicolumn{3}{|c|}{$\begin{array}{c}\text { Residual Candle Filter Surface } \\
\text { Dust Cake Layers, wt\% }\end{array}$} & \multicolumn{3}{|c|}{ Ash Bridges, wt\% } \\
\hline & $\mathrm{T} 26$ & M26 & B31 & $\begin{array}{c}\text { Top } \\
\text { Plenum }\end{array}$ & $\begin{array}{l}\text { Middle } \\
\text { Plenum }\end{array}$ & $\begin{array}{l}\text { Bottom } \\
\text { Plenum }\end{array}$ \\
\hline Calcium Sulfate $\left(\mathrm{CaSO}_{4}\right)$ & 58.0 & 55.0 & 52.6 & 56.2 & 49.8 & 55.3 \\
\hline Quartz $\left(\mathrm{SiO}_{2}\right)$ & 12.4 & 11.3 & 12.8 & 11.5 & 11.9 & 15.8 \\
\hline Hematite $\left(\mathrm{Fe}_{2} \mathrm{O}_{3}\right)$ & 11.0 & 12.0 & 12.0 & 10.8 & 8.0 & 11.2 \\
\hline $\begin{array}{l}\text { Feldspar/ Plagioclase } \\
(\mathrm{Ca}, \mathrm{Na})(\mathrm{Al}, \mathrm{Si})_{2} \mathrm{Si}_{2} \mathrm{O}_{8} \\
\end{array}$ & 9.5 & 9.5 & 10.9 & 10.6 & 11.7 & 7.6 \\
\hline $\begin{array}{l}\text { Pyroxene/Clinopyroxene } \\
\left(\mathrm{Ca}\left(\mathrm{Mg}, \mathrm{Fe}^{+3}, \mathrm{Al}\right)(\mathrm{Si}, \mathrm{Al})_{2} \mathrm{O}_{8}\right)\end{array}$ & 9.0 & 12.1 & 11.7 & 11.0 & 18.6 & 10.2 \\
\hline
\end{tabular}

(a) Illinois coal and Linwood limestone/Iowa Industrial limestone/Resized Linwood limestone deposit. 
In view of the XRD analyses presented in Tables 10 and 11 , a significantly reduced concentration of $\alpha-\mathrm{SiO}_{2}$ was identified in the PCFBC dust cake formations that resulted within the filter cluster assembly during Test Segment 3 . In contrast a greater concentration of feldspars and/or aluminosilicates was identified in Test Segment 3's dust cake formations. The reduced concentration of $\alpha-\mathrm{SiO}_{2}$ present within the melt-like necks or channels between adjacent particles, and the increased concentration in the aluminosilicate phases were considered to contribute to limiting the extent of ash bridging during PCFBC operation in Test Segment 3.

\section{Thermal Expansion}

As shown in Figure 42, the porous ceramic filter materials have a lower thermal expansion in comparison to the PCFBC or PFBC ash materials. The PCFBC ash used in the thermal expansion testing was representative of the dust cake layer that remained along the outer surface of the candle filters at the conclusion of Test Segment 2 at the Foster Wheeler test facility in Karhula, Finland. In contrast the PFBC ash sample was removed from the densely packed ash plug that formed within the i.d. bore of the filter elements during Test Segment 5 at the American Electric Power Tidd Demonstration Plant in Brilliant, Ohio. The relatively wide variation in the thermal expansion of the ash materials as a function of temperature was considered to reflect the difference in the density of the materials, and possibly the variation in the composition of the ash deposits.

\section{Density, Moisture Content, and Compressive Strength}

Room temperature compressive strength testing was conducted on fourteen ash deposits that were removed from the $\underline{\mathrm{W}}-\mathrm{APF}$ at the conclusion of Test Segment 2. Typically the deposits were cut into either cubic or rectangularly shaped samples prior to testing. In addition, the moisture content and bulk density of the samples were determined.

As shown in Table 12, the density of the ash deposits ranged between 0.428 and $0.718 \mathrm{gm} / \mathrm{cm}^{3}$, and the moisture content ranged between 0.02 and $0.07 \%$. The room temperature compressive strength of the PCFBC ash deposits ranged between 0.7 and 34.4 psi. In addition,

- Variation in compressive strength was identified to exist within ash deposits formed at a given sample location.

- The compressive strength of the ash bridges that formed between filter elements was shown to be approximately equivalent to the compressive strength of the hopper ash deposit. ${ }^{9}$

- The candle filter ash cake appeared to be weaker than the ash deposits that formed between adjacent filter elements, or between the filter elements and the plenum pipe.

- The dust shed deposits appeared to be weaker than the candle filter cake deposits.

- The compressive strengths of the filter holder deposits and isolated bridges that formed near the bottom of the filter elements were nearly identical (Table 13). The isolated bridges may have resulted from the collection of ash that had fallen from the metal holders.

\footnotetext{
${ }^{9}$ Large deposit; Not free flowing ash fines discharged from the hopper.
} 


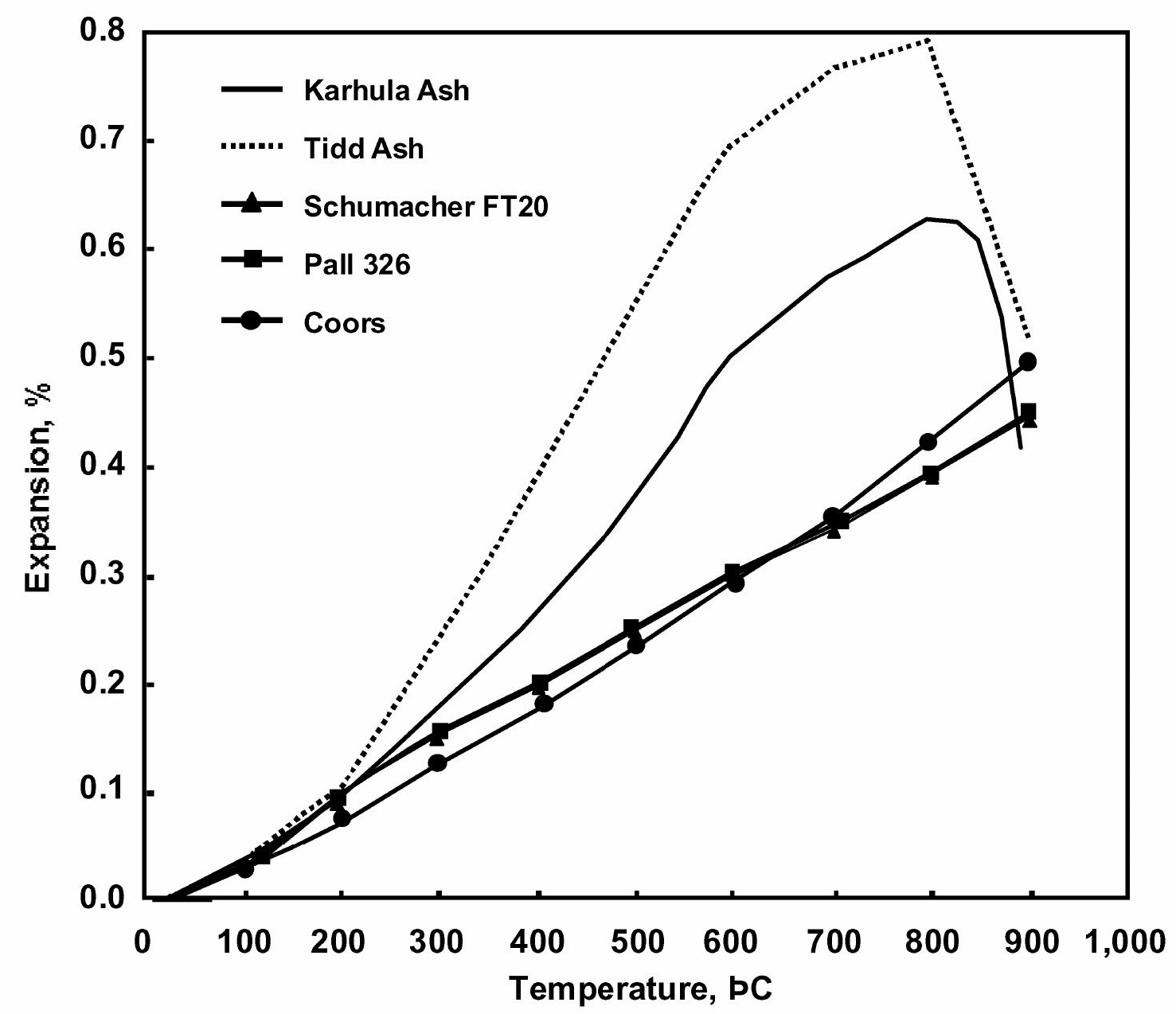

Figure 42 - Thermal expansion of the porous ceramic filter materials and ash formations. 


\begin{tabular}{|c|c|c|c|c|c|c|c|}
\hline \multicolumn{8}{|c|}{$\begin{array}{c}\text { ASH DEPOSIT CHARACTERIZATION } \\
\text { - Test Segment } 2 \text { - }\end{array}$} \\
\hline Sample Identification & $\begin{array}{l}\text { Width, } \\
\text { in }\end{array}$ & $\begin{array}{l}\text { Thickness, } \\
\text { in }\end{array}$ & $\begin{array}{l}\text { Length, } \\
\text { in }\end{array}$ & $\begin{array}{l}\text { Density, } \\
\text { gm/cm }\end{array}$ & $\begin{array}{l}\text { Load, } \\
\text { lbs }\end{array}$ & $\begin{array}{l}\text { Strength, } \\
\text { psi }\end{array}$ & $\begin{array}{l}\text { Percent }{ }^{(a)} \\
\text { Moisture }\end{array}$ \\
\hline $\begin{array}{c}\text { Top Array } \\
\text { Candle Surface Ash From } \\
\text { Top Of T15 }\end{array}$ & $\begin{array}{l}0.412 \\
0.611 \\
\end{array}$ & $\begin{array}{l}0.380 \\
0.461 \\
\end{array}$ & $\begin{array}{l}0.624 \\
0.724 \\
\end{array}$ & $\begin{array}{l}0.616 \\
0.428 \\
\end{array}$ & $\begin{array}{l}0.7 \\
2.8\end{array}$ & $\begin{array}{l}2.9 \\
6.3 \\
\end{array}$ & 0.05 \\
\hline $\begin{array}{c}\text { Top Array } \\
\text { Bridges Between T14-T15 } \\
\text { Bottom Of Bridge }\end{array}$ & $\begin{array}{l}0.460 \\
0.448\end{array}$ & $\begin{array}{l}0.450 \\
0.445\end{array}$ & $\begin{array}{l}0.775 \\
0.800\end{array}$ & $\begin{array}{l}0.626 \\
0.611\end{array}$ & $\begin{array}{l}6.2 \\
6.8\end{array}$ & $\begin{array}{l}17.4 \\
18.8\end{array}$ & 0.05 \\
\hline $\begin{array}{l}\text { Top Array } \\
\text { Bridges Between T5-T6 } \\
\text { Bottom Of Candles }\end{array}$ & 0.545 & 0.520 & 0.635 & 0.583 & 1.9 & 5.3 & 0.04 \\
\hline $\begin{array}{c}\text { Middle Array } \\
\text { Candle Surface Ash From } \\
\text { Middle Of M14 }\end{array}$ & $\begin{array}{l}0.627 \\
0.600 \\
\end{array}$ & $\begin{array}{l}0.402 \\
0.405 \\
\end{array}$ & $\begin{array}{l}0.906 \\
0.880 \\
\end{array}$ & $\begin{array}{l}0.621 \\
0.595 \\
\end{array}$ & $\begin{array}{l}9.6 \\
8.1\end{array}$ & $\begin{array}{l}16.9 \\
15.3\end{array}$ & 0.02 \\
\hline $\begin{array}{c}\text { Middle Array } \\
\text { Bridging At Top Of Candles } \\
\text { Between M7-M8 } \\
\text { Middle Of Bridge }\end{array}$ & $\begin{array}{l}0.635 \\
0.590\end{array}$ & $\begin{array}{l}0.485 \\
0.540\end{array}$ & $\begin{array}{l}0.874 \\
0.950\end{array}$ & $\begin{array}{l}0.588 \\
0.558\end{array}$ & $\begin{array}{l}5.4 \\
6.4\end{array}$ & $\begin{array}{c}9.7 \\
11.4\end{array}$ & 0.04 \\
\hline $\begin{array}{c}\text { Middle Array } \\
\text { Bridging At Top Of Candles } \\
\text { Between M7-M8 } \\
\text { Bottom Of Bridge }\end{array}$ & $\begin{array}{l}0.535 \\
0.530\end{array}$ & $\begin{array}{l}0.445 \\
0.425\end{array}$ & $\begin{array}{l}0.616 \\
0.950\end{array}$ & $\begin{array}{l}0.631 \\
0.660\end{array}$ & $\begin{array}{l}5.4 \\
9.3\end{array}$ & $\begin{array}{l}16.4 \\
18.5\end{array}$ & 0.04 \\
\hline $\begin{array}{c}\text { Middle Array } \\
\text { Bridge At Bottom Of Candles } \\
\text { Between M19-M21 } \\
\text { Middle Of Bridge }\end{array}$ & $\begin{array}{l}0.590 \\
0.580\end{array}$ & $\begin{array}{l}0.440 \\
0.510\end{array}$ & $\begin{array}{l}1.125 \\
0.885\end{array}$ & $\begin{array}{l}0.543 \\
0.555\end{array}$ & $\begin{array}{l}3.5 \\
1.3\end{array}$ & $\begin{array}{l}5.3 \\
2.5\end{array}$ & 0.02 \\
\hline $\begin{array}{l}\text { Middle Array } \\
\text { Ash On Shed }\end{array}$ & $\begin{array}{l}0.510 \\
0.460\end{array}$ & $\begin{array}{l}0.506 \\
0.205\end{array}$ & $\begin{array}{l}0.815 \\
0.575\end{array}$ & $\begin{array}{l}0.718 \\
0.679\end{array}$ & $\begin{array}{l}2.1 \\
2.9\end{array}$ & $\begin{array}{c}5.1 \\
11.0\end{array}$ & 0.04 \\
\hline
\end{tabular}

(a) Samples heated at $110^{\circ} \mathrm{C}$ for $66 \mathrm{hrs}$. 
TABLE 12 (Continued)

ASH DEPOSIT CHARACTERIZATION

— Test Segment 2 -

\begin{tabular}{|c|c|c|c|c|c|c|c|}
\hline Sample Identification & $\begin{array}{l}\text { Width, } \\
\text { in }\end{array}$ & $\begin{array}{c}\text { Thickness, } \\
\text { in }\end{array}$ & $\begin{array}{l}\text { Length, } \\
\text { in }\end{array}$ & $\begin{array}{l}\text { Density, } \\
\mathrm{gm} / \mathrm{cm}^{3}\end{array}$ & $\begin{array}{l}\text { Load, } \\
\text { lbs }\end{array}$ & $\begin{array}{l}\text { Strength, } \\
\text { psi }\end{array}$ & $\begin{array}{l}\text { Percent }^{(a)} \\
\text { Moisture }\end{array}$ \\
\hline $\begin{array}{l}\text { Top Array } \\
\text { Filter Holder Deposit } \\
\text { Near T22 }\end{array}$ & 0.370 & 0.342 & 0.766 & 0.494 & 0.2 & 0.7 & 0.072 \\
\hline $\begin{array}{c}\text { Middle Array } \\
\text { Filter Holder Deposit } \\
\text { Between M16-M17 }\end{array}$ & $\begin{array}{l}0.701 \\
0.524\end{array}$ & $\begin{array}{l}0.460 \\
0.485\end{array}$ & $\begin{array}{l}0.633 \\
0.798\end{array}$ & $\begin{array}{l}0.604 \\
0.528\end{array}$ & $\begin{array}{l}2.2 \\
1.3 \\
\end{array}$ & $\begin{array}{l}5.0 \\
3.0\end{array}$ & 0.034 \\
\hline $\begin{array}{c}\text { Middle Array } \\
\text { Filter Holder Deposit } \\
\text { Between M18-M19 }\end{array}$ & $\begin{array}{l}0.750 \\
0.573 \\
\end{array}$ & $\begin{array}{l}0.594 \\
0.497 \\
\end{array}$ & $\begin{array}{l}0.615 \\
0.559 \\
\end{array}$ & $\begin{array}{l}0.525 \\
0.521 \\
\end{array}$ & $\begin{array}{l}3.1 \\
2.9 \\
\end{array}$ & $\begin{array}{l}6.7 \\
9.1 \\
\end{array}$ & 0.034 \\
\hline $\begin{array}{c}\text { Middle Array } \\
\text { Bridge Near Top Of Candles } \\
\text { Between M15-M16 } \\
\text { Top Of Bridge }\end{array}$ & $\begin{array}{l}0.569 \\
0.679 \\
0.597 \\
\end{array}$ & $\begin{array}{l}0.540 \\
0.572 \\
0.589 \\
\end{array}$ & $\begin{array}{l}0.613 \\
0.680 \\
0.768 \\
\end{array}$ & $\begin{array}{l}0.552 \\
0.527 \\
0.580 \\
\end{array}$ & $\begin{array}{l}12.0 \\
3.9 \\
6.9 \\
\end{array}$ & $\begin{array}{c}34.4 \\
8.3 \\
15.1 \\
\end{array}$ & 0.038 \\
\hline $\begin{array}{c}\text { Bottom Array } \\
\text { Bridge At Top Of Candle } \\
\text { Bottom Of Bridge }\end{array}$ & $\begin{array}{l}0.457 \\
0.613\end{array}$ & $\begin{array}{l}0.366 \\
0.361\end{array}$ & $\begin{array}{l}0.775 \\
0.851\end{array}$ & $\begin{array}{l}0.629 \\
0.611\end{array}$ & $\begin{array}{l}4.4 \\
3.5 \\
\end{array}$ & $\begin{array}{c}12.4 \\
6.7\end{array}$ & 0.056 \\
\hline Hopper Deposit & $\begin{array}{l}0.549 \\
0.584\end{array}$ & $\begin{array}{l}0.538 \\
0.471\end{array}$ & $\begin{array}{l}0.766 \\
0.850\end{array}$ & $\begin{array}{l}0.641 \\
0.625\end{array}$ & $\begin{array}{l}6.5 \\
8.8\end{array}$ & $\begin{array}{l}15.3 \\
17.7\end{array}$ & 0.056 \\
\hline
\end{tabular}

(a) Samples heated at $110^{\circ} \mathrm{C}$ for $52 \mathrm{hrs}$. 


\begin{tabular}{|c|c|}
\hline \multicolumn{2}{|c|}{$\begin{array}{c}\text { ROOM TEMPERATURE COMPRESSIVE STRENGTH } \\
\text { OF PCFBC ASH DEPOSITS } \\
- \text { Test Segment } 2-\end{array}$} \\
\hline Location & $\begin{array}{c}\text { Average Strength } \pm 1 \sigma, \text { psi } \\
\text { (Number of Samples Characterized) }\end{array}$ \\
\hline Filter Holders & $4.9 \pm 3.3(5)$ \\
\hline $\begin{array}{l}\text { Bridges Between Candle Filters } \\
\text { (Top, Middle, Bottom Locations) }\end{array}$ & $15.4 \pm 7.6(11)$ \\
\hline $\begin{array}{c}\text { Isolated Bridges At The Bottom } \\
\text { Of The Filter Elements }\end{array}$ & $4.4 \pm 1.6(3)$ \\
\hline Candle Filter Cake & $10.4 \pm 6.8(4)$ \\
\hline Dust Shed & $8.1 \pm 4.2(2)$ \\
\hline Hopper & $16.5 \pm 1.7(2)$ \\
\hline
\end{tabular}


The average density of all twenty-seven PCFBC ash samples was $0.587 \mathrm{~g} / \mathrm{cm}^{3}$ which was comparable to the density of the PFBC bridges that formed at the conclusion of Test Segments 3 and 4 at AEP. Clearly the density of the PCFBC ash deposits was less than the density of the deposits that formed within the i.d. bore of the filter elements (i.e., $1.19 \mathrm{~g} / \mathrm{cm}^{3}$ ), ${ }^{10}$ or along the metal filter holders along the top array at the conclusion of Test Segment 5 at AEP (i.e., 0.6-0.85 g/ $\mathrm{cm}^{3}$ ). Similar analyses were not conducted on the PCFBC ash formations that resulted within the W-APF at the Foster Wheeler test facility in Karhula, Finland, at the conclusion of Test Segment 3.

\section{Summary}

The stability of the commercially available oxide-based Coors P-100A-1 alumina/mullite and the high temperature creep resistant clay bonded silicon carbide Schumacher Dia Schumalith FT20 and Pall 326 candle filters was demonstrated during 1166 hours of operation in the Foster Wheeler PCFBC test facility in Karhula, Finland. Both the Coors and Pall matrices experienced an initial loss of bulk material strength while undergoing numerous microstructural changes. In contrast the strength of the Schumacher matrix remained virtually unchanged while numerous microstructural changes were encountered.

Based on the analyses conducted in this program, oxidation of the clay bonded silicon carbide Schumacher Dia Schumalith FT20 and Pall 326 candle filters was considered to have occurred which promoted elongation of the elements during extended PCFBC operation. Oxidation, as well as removal of the oxidized CVI-SiC deposited layer resulted along the outer confinement and filtration mat layers of the $3 \mathrm{M} \mathrm{CVI-SiC} \mathrm{composite} \mathrm{filter} \mathrm{matrix.} \mathrm{A} \mathrm{rapid} \mathrm{reduction} \mathrm{in} \mathrm{bulk} \mathrm{strength,} \mathrm{leading} \mathrm{to} \mathrm{the} \mathrm{general}$ conditioning of the $3 \mathrm{M}$ CVI-SiC composite matrix subsequently resulted during operation in the PCFBC environment.

As a result of testing at Karhula, the oxide-based Coors P-100A-1 alumina/mullite candle filters continue to show promise for achieving extended PCFBC operating life in advanced coal-fired applications. Continued exposure of the Coors P-100A-1 alumina/mullite, Schumacher Dia Schumalith FT20, and Pall 326 candle filters in the PCFBC environment, followed by accelerated life cycle testing is recommended. Similarly monitoring the impact of oxidation of the clay bonded silicon carbide filter elements, and the associated elongation of the candles is essential to determine the long-term viability of the high temperature creep resistant Schumacher Dia Schumalith FT20 and Pall 326 filter matrices. Development of an oxidation resistant coating along the surface of the silicon carbide grains, as well as throughout the 3M CVI-SiC composite filter matrix, or alternately manufacturing a complete oxide matrix/fiber composite candle filter may foster improved life of the fiber reinforced composite filter elements.

Characterization of the dust cake deposits which formed throughout the $\underline{\mathrm{W}}$-APF filter cluster identified calcium sulfate and quartz as primary phases, with hematite present as a secondary phase. Complex aluminosilicates were detected as minor phases within the ash cake deposits. The potential cohesivity or "stickiness" of the dust cake layer due to the presence of silica or silicates, the impact of particle size within the various deposits, and the relationship of the coal feed and sorbent composition on the resulting dust cake chemistry are areas which warrant continued investigation in order to achieve viable commercial operation of advanced hot gas filtration systems.

\footnotetext{
${ }^{10}$ Filling of the candle i.d. bore resulted from back pulsing of fines released into the clean process gas stream after failure of alternate filter elements had occurred.
} 


\section{Acknowledgments}

We wish to acknowledge Mr. Richard Dennis at DOE/FETC for his guidance and technical support during conduct of the filter material surveillance program. We also wish to acknowledge Mr. Reijo Kuivalainen, Mr. Juhani Isaksson, Mr. Timo Eriksson, and Mr. Pekka Lehtonen for their efforts in conducting the hot gas filtration test program at the Foster Wheeler PCFBC test facility in Karhula, Finland. The technical guidance and analytical support provided by Dr. Richard Tressler at the Pennsylvania State University, and the mechanical testing conducted by Mr. Robert Walko and Mr. Eugene Smeltzer, and the spectroscopy and phase analyses performed by Mr. Thomas Mullen, Ms. Paula Freyer, and Dr. Art Byers at the Westinghouse Science and Technology Center are also gratefully acknowledged. 